\title{
An 'Organ of Student Opinion'? Alternative Print, Protest, and the Politics of Education in Salient, 1973-1989
}

\section{Max Nichol}

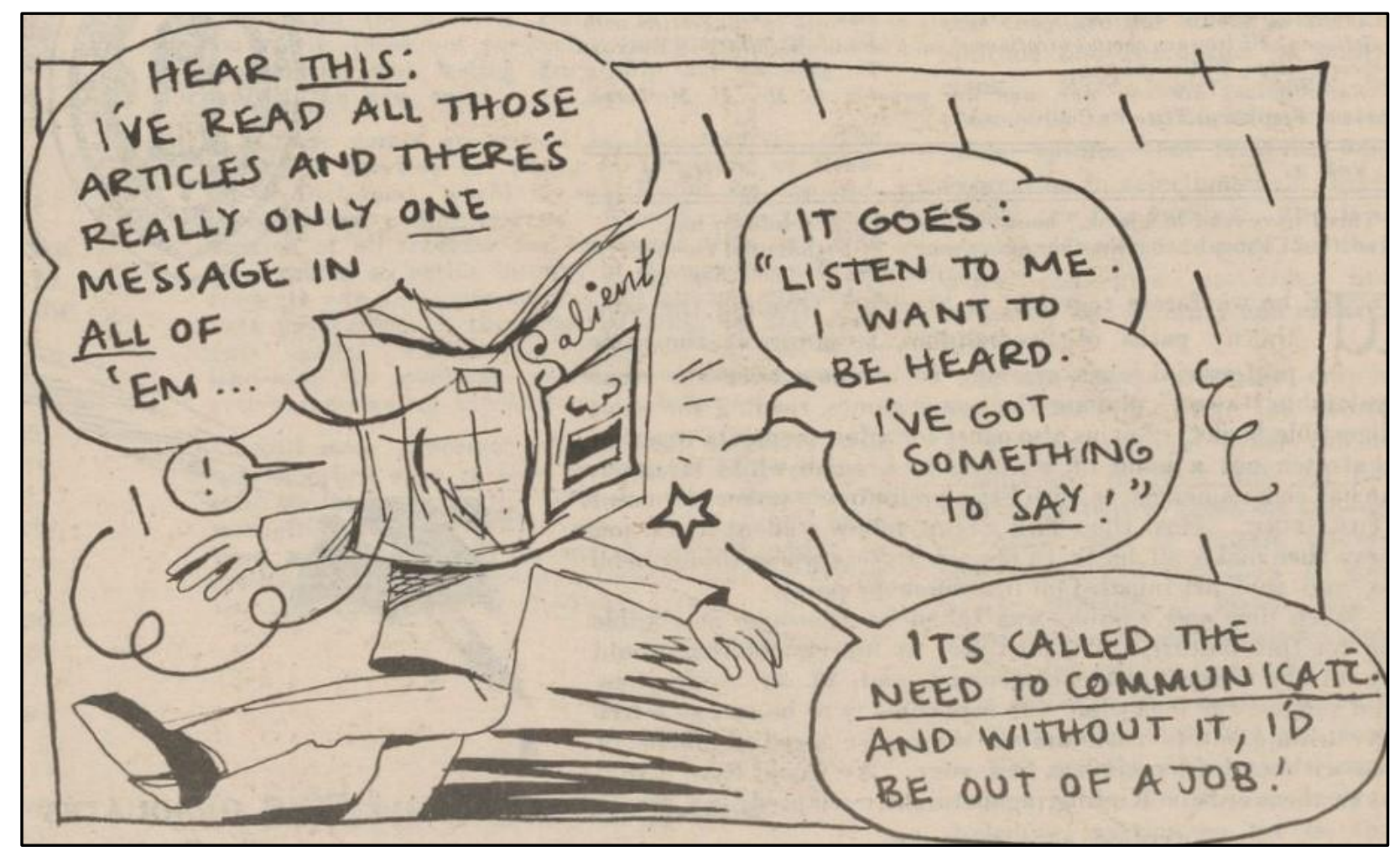

Image: Tim Bollinger, 'Salient - The Newspaper Speaks...', Salient, Vol. 50, No. 10, 25 May 1987, p.19.

A Thesis Submitted to Victoria University of Wellington in Fulfilment of the Requirements for the Degree of Master's of Arts in History 


\section{TABLE OF CONTENTS}

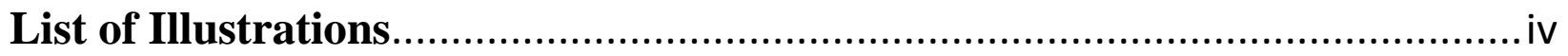

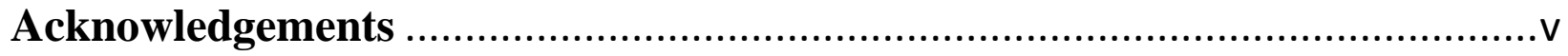

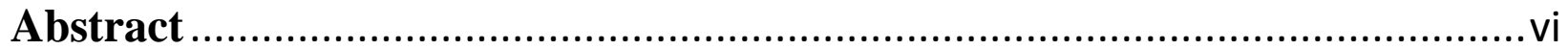

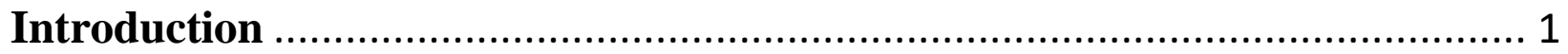

Chapter One - "SALI 101": An Overview of the Production and Print

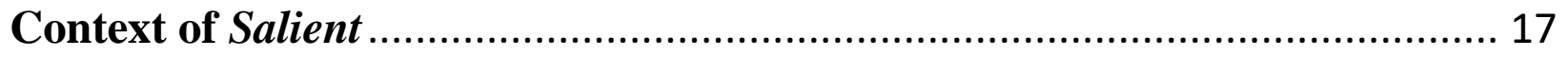

Chapter Two - Salient Through the Long 1970s: Activism and Socialism,

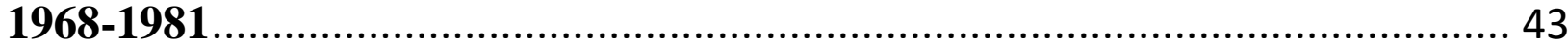

Chapter Three - Changing Contexts, New Challenges: Salient's Response to Neoliberal Education Reform, 1982-1989................................................ 83

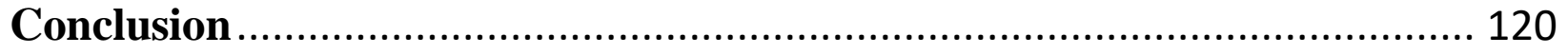

Appendix - Salient editors 1970-1990 .................................................... 125

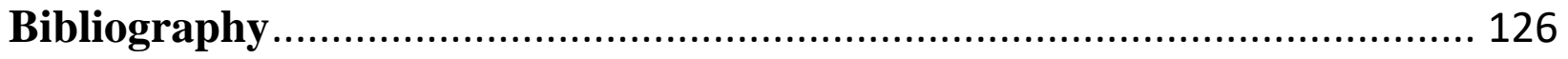




\section{LIST OF ILLUSTRATIONS}

\begin{tabular}{|c|c|c|}
\hline Figure & Illustration & Page \\
\hline 1 & $\begin{array}{l}\text { Blank cover of Salient Vol. 45, No. 2, following the printer's removal of the } \\
\text { front-page story. }\end{array}$ & 37 \\
\hline 2 & Covers of the National Student Issues for 1987 and 1989. & 41 \\
\hline 3 & $\begin{array}{l}\text { Cartoon of Salient editor Peter Franks during an NZUSA visit to China in } \\
1973\end{array}$ & 48 \\
\hline 4 & Selection of protest advertisements from Salient in the mid-1970s & 50 \\
\hline 5 & Route of the South Island Resistance Ride in 1975 , as portrayed in Salient. & 53 \\
\hline 6 & $\begin{array}{l}\text { Cartoon of Bruce Robinson and John Henderson discussing socialist theory, } \\
1975 .\end{array}$ & 69 \\
\hline 7 & $\begin{array}{l}\text { Stressed student overwhelmed by VUWSA Education Officer’s work } \\
\text { against high workloads in } 1976 .\end{array}$ & 72 \\
\hline 8 & $\begin{array}{l}\text { Cartoon depicting Labour's inaction on the Standard Tertiary Bursary prior } \\
\text { to the } 1975 \text { election. }\end{array}$ & 74 \\
\hline 9 & $\begin{array}{l}\text { Cover of Salient featuring a banner hung from the Rankine Brown Building } \\
\text { in protest of user pays education policies, } 1989 .\end{array}$ & 113 \\
\hline
\end{tabular}




\section{ACKNOWLEDGEMENTS}

First and foremost, thanks are due to Cybèle Locke, who supervised this thesis. Your extensive knowledge of the communist left and trade unions in New Zealand proved to be invaluable. Thank you for the chats, the comments, and for seeing the potential in this project from the very beginning.

The History Department at Victoria University of Wellington is a first-rate place to study. Thank you to all of the staff and my fellow postgraduate students who in sharing their research and expertise have greatly enriched this thesis and the process of writing it. School Administrator Teresa Durham deserves specific mention for all of the incredible work she does to make the Department run smoothly.

Particular thanks also to Professor Charlotte Macdonald and Dr Rebecca Lenihan, both of whom provided valuable thoughts and advice at the beginning of my research. More importantly, both played an integral role in my decision to pursue postgraduate study in history in the first place. I will always be grateful to you both for setting me on this path.

Thanks to my family, for their unwavering love and support during my time at Victoria University, and to all of the incredible friends who have supported me as I researched and wrote this thesis.

Many thanks to Melissa Harward and Kiriana Haze, my flatmates in 2018. The warmth and brightness you brought to our home on The Terrace almost made up for how freezing it was.

I am immensely grateful to Mark Cubey, Peter Franks, Jane Hurley, Roger Steele, Margie Thomson, and Simon Wilson, who agreed to be interviewed for this project. Your thoughts and reflections on your time at Salient shaped this thesis in ways both big and small. Thank you for sharing.

Thank you to the editor of Salient in 2018, Louise Lin, and the co-editors in 2019, Taylor Galmiche and Kii Small, for the opportunity to contribute a "From the Archives" column to Salient. It was a great creative outlet and allowed me to make use of some of the material which did not make it into this thesis.

The bequest of F P Wilson, former Professor of History at Victoria University of Wellington, provided a scholarship at the beginning of this research. It seems fitting that it contributed to the writing of a thesis which further illuminates the history of the university he worked in. 


\section{ABSTRACT}

This thesis explores Victoria University of Wellington's student newspaper, Salient, in the 1970s and 1980s. Salient covered a wide array of issues, performing its role as a campus newspaper while closely engaging with and informing students of wider political issues during a period of significant student protest. As a publication, it consistently and deliberately set itself apart from the mainstream media, a position which placed it alongside other alternative or radical publications. Furthermore, the thesis demonstrates that the connections between Salient and the Wellington Marxist-Leninist Organisation (MILO) were profound and enduring in the 1970s, with significant implications for the kinds of analysis and issues that Salient presented to its readers. While individual editors did have unique editorial policies, the nature of Salient's journalism in the 1970s was notably socialist and activist in its outlook. In the 1980s, while Salient maintained a progressive political outlook, the direct association with MILO (by then the Workers' Communist League) loosened. The paper's political content still covered a range of contemporary social issues, and its editors took political stances, but its content was more akin to political commentary than an extension of political activism. The exception was Salient's opposition to user pays tertiary education, which was seriously considered by David Lange's Labour Government as part of its neoliberal reforms. As the possibility of a user-pays tertiary education system became more likely, Salient dedicated more space to covering, opposing, and organising action against this disruptive policy which had major implications for its student readership. Salient often did not speak for all students, but provided a platform for alternative analysis of social and political issues,

pushing the boundaries of the purpose of student media and its place within the print landscape of New Zealand. 


\section{Introduction}

Student newspapers occupy an almost unique area of the print media in New Zealand. They can do, in essence, what they damn well please. They are not bound by the normal constraints on newspapers - advertising, sales and so-called 'objective' journalism. ${ }^{1}$

This is a history of Victoria University of Wellington's (VUW) long-standing student newspaper Salient, between the years of 1973 and 1989. In the quote above, Salient editor Richard Adams captures many of the themes this thesis investigates - the significance of Salient's funding relationship with the Victoria University of Wellington Students' Association (VUWSA), the irreverence for mainstream journalistic conventions, and the amateur spirit of so many of its contributors. Across the 1970s and 1980s, Salient regularly and intentionally positioned itself in opposition to the mainstream press, rejecting the notion that objective journalism was an attainable or even desirable standard of reporting. As such, Salient should be understood within the alternative print culture of the time which made significant contributions to the organisation of political protest activity. However, it was different from other alternative publications in a number of important ways. Due to its relationship with its printer, Wanganui Newspapers, and the need to manage a relationship with VUWSA, its publisher and funding body, it was perhaps not as radical as other alternative media at the time. However, that relationship with VUWSA also lent it a financial security and regularity of publication not afforded to other alternative publications, meaning it was likely one of the most widely read alternative publications in Wellington at the time. It had a large audience in the ever-expanding student body of VUW (not all of which supported Salient's content) as well as having some readers among the wider Wellington public and students at other universities. Despite this, the histories of student publications like Salient have not been explored in much depth. This thesis examines more specifically than previous accounts the issues and events Salient covered and the content it produced, with a view to explaining what was informing that coverage. Key questions this thesis considers are how did the historical context and the personal politics of Salient's editors influence the newspaper's content?

\footnotetext{
${ }^{1}$ Richard Adams, 'Editorial', Salient: National Student Issue, Vol. 48, No. 17, 1986, p.3. This issue was the product of a collaboration between Massey University's Chaff, Lincoln University's Caclin, the University of Otago's Critic, the University of Canterbury's Canta, and Victoria University of Wellington's Salient. The University of Auckland's Craccum was notably absent, having failed to get its contributions to Wellington in time for the issue to be typeset.
} 
What were the relevant contemporary issues that Salient engaged with, how did its editors analyse those issues, and how did they emerge in the pages of Salient?

Salient editors were radicalised by the anti-Vietnam War and anti-Apartheid movements of the late 1960s and early 1970s. Many editors became members of the Wellington Marxist Leninist Organisation (MILO), which became the Workers' Communist League (WCL) in 1979. How Maoist-informed socialism influenced Salient is noteworthy. At some level, Salient operated as a publication which pushed MILO's agenda to a student readership in an effort to increase its membership and its support amongst the student body. However, editors who were not members of MILO also pushed class-based analyses. From 1973, socialist analyses were applied to a wide variety of issues and manifested in strong support for militant trade unionism in Salient. As a student newspaper, this socialist line was often couched in terms relevant to student interests. In the mid-1970s, Salient called for a radical reimagination of the university itself which would see it decoupled from the elitist ruling classes. In the second half of the 1970s, as Robert Muldoon took a knife to education funding and industrial relations, Salient pushed the need for solidarity between students and workers, while simultaneously seeking to protect and improve funding which allowed students of all class backgrounds access to the university. This socialist analysis was integrated with active involvement in organising and reporting on protest in Wellington. The production of the paper and the style of activist journalism it deployed was intertwined with the political activity which its editors performed outside of it. The high-point of this kind of journalism was in Salient's coverage of the 1981 Springbok Tour, in which Salient acted as a focal point for organisation of anti-tour activities and an alternative source of information from the mainstream media.

This protest action was multi-issue, with a particular focus on opposing the Vietnam War and sporting contact with the South African apartheid regime. In New Zealand, protest erupted on parliament grounds in June 1968, forcing the cancellation of the outdoor opening of parliament; two arrests were made. The most significant issue was the recently announced Nil Wage Order, which resulted in an effective cut in wages for workers in industries whose wages were determined by the Arbitration Court. The ensuing demonstration at the opening of parliament brought together workers protesting the wage order, students protesting the level of bursaries, and Māori protesting the Māori Affairs Amendment Act 1967, dubbed “the last land grab”. In New Zealand, the spirit of ' 68 was more about what was to come than what was achieved in 1968 itself. Students and 
workers were aware of and inspired by the political and cultural upheaval happening across the world - 1968 laid the groundwork for the emergence of an expansive, energetic, and multi-issue protest culture in the 1970s. Due to issues of space, this thesis does not consider Salient's coverage on all of the protest movements which flowed from the late 1960s, instead exploring a few in depth to demonstrate its political reporting.

Following the 1981 Springbok Tour, the influence of socialist analysis in the pages of Salient became less pronounced. The paper remained political, taking positions on the issues of the day. However, less reporting was framed by class. A general decline in the level of student protest also meant that Salient's political reporting was more akin to political commentary than to activist journalism. Salient's editors still had much to say about the conditions of New Zealand and the world, but this was not as closely integrated with direct protest action as in the 1970s. Salient also had its first women editors in over forty years. While Salient had covered women's issues in the 1970s, Sally Zwartz and Jane Hurley challenged Salient's male-dominated past and unpacked what it signalled about the ongoing struggle for women's liberation. Salient also contended with the ideas of Māori sovereignty. For the most part its contributors, reflecting university demographics, were Pākehā, and like many liberal Pākehā the contributors to Salient supported an end to racism in New Zealand. However, they were baffled and threatened by the more all-encompassing call by Māori nationalists to overthrow the patriarchal, capitalist, and (most importantly) colonial state of New Zealand. The election of David Lange's Labour Government brought sweeping neoliberal reforms that threatened university funding and student support at a fundamental level. With the looming possibility of a user-pays tertiary education sector and a crisis in student politics, the gravity of this threat forced Salient's editors to dedicate far more of their coverage to matters of direct interest to students. Its coverage of education policy continued to be political, but by the end of the 1980s, Salient had lost some of its radical edge.

The first volume of Salient was published in 1938, with Alfred H. 'Bonk' Scotney as its founding editor. The masthead declared Scotney's vision that Salient would be an "Organ of Student Opinion at Victoria College". ${ }^{2}$ Initially sold for threepence, by the 1970s it had become the official publication of VUWSA, which provided most of the funding through Association fees. As a body of work, it charts a course through over eighty years of student writing, student experience, and the development of VUW. Salient's founding editor A.H. Bonk Scotney expressly

\footnotetext{
${ }^{2}$ A.H. Scotney, 'Salient', Salient, Vol. 1, No. 1, 9 March 1938, p.1.
} 
intended the publication to offer an outspoken political voice on the left. But there have been periods in which the instruments of Victoria's student politics, the Students Association executive and Salient, have been controlled by more conservative students. Rachel Barrowman notes that the 1950s "was not an exciting period politically", with conservatives stacking the benches of both the VUWSA executive and Salient's editorial staff. One of Salient's editors in 1951 went so far as to "expressly repudiate the paper's own red tradition". ${ }^{3}$ The editorial policy of Salient for the next few years focussed predominantly on campus news instead of political issues. From 1968 onwards, Salient returned to a tradition of challenging, overtly political journalism. ${ }^{4}$ This thesis charts the development and manifestation of this tradition across the following two decades.

\section{Historiography}

Very little historical work has been done on student media in New Zealand. This is despite the longevity of many student publications in New Zealand - Salient is publishing its eightysecond volume in 2019 - and the unique position they hold in the print landscape of New Zealand. Two honours dissertations have placed New Zealand student media at their centre, exploring how contemporary forces shaped their content. Andrew Hart's study of student culture at the University of Auckland in the 1960s takes the university's long-standing publication Craccum as well as the short-lived Outspoke as its primary source base. ${ }^{5}$ He uses these publications to question present day nostalgia for a rowdy and enduring "student culture" of the past, since lost to Auckland's students (but not to the scarfies of Dunedin). He demonstrates that in fact, students at the University of Auckland in the 1960s "developed a pragmatic and somewhat conformist culture" in its relationship to the university. He argues that these bear striking similarities to the solemn assessments of "student culture" made by present day Craccum editors. ${ }^{6}$ Jasmine Freemantle conducted a survey of "non-heterosexuals and non-heterosexuality" in Salient across its history. She argues that from the 1970s onwards, Salient's editors generally began to give greater prominence, even outright support, to queer and non-heterosexual people and identities in Salient. She suggests that this reflected "changing attitudes and prerogatives among both society in general,

\footnotetext{
${ }^{3}$ Rachel Barrowman, Victoria University of Wellington 1899-1999: A History (Wellington: Victoria University Press, 1999), p.319.

4 Paul Wiggins, '50 Year Plan', Salient. Vol. 50, No. 10, 25 May 1987, p.11.

${ }^{5}$ Andrew Hart, "Student Perspectives: Auckland University Student Newspapers in the 1960s" (Honours

Dissertation, University of Auckland, 2016), pp.2-3.

${ }^{6}$ Hart, p.27.
} 
and from within the "queer community"' regarding the acceptability of being openly queer. ${ }^{7}$ While she is clear that her study was focussed on this single thread of coverage, her conclusions about Salient's general qualities are shared with this project; namely, that Salient has "adequately fulfilled the role of a 'general alternative publication"' and that it deliberately rejected mainstream notions of objectivity. ${ }^{8}$

Histories of individual universities and students' associations in New Zealand also consider student media. Currently, there are histories of most of New Zealand's established universities, and a number of their students' associations. ${ }^{9}$ For the most part these histories deploy student publications as sources to reflect on the particular institution they address. When they do consider student publications as publications in their own right, this is discussed only briefly. Histories of Victoria University of Wellington obviously have the most immediate relevance to this project. Between them, Rachel Barrowman and Stephen Hamilton have respectively contributed institutional histories of VUW and VUWSA. Both were produced to commemorate the centenary of VUW in 1999. Barrowman takes a top-down view of the university, exploring in detail the development of academic departments and programmes, notable professors and academics, and the built environment of VUW. Her exploration of student life is relatively limited by design, noting that as Hamilton's history was being produced at the same time, his history would be able to illuminate student culture in greater detail. ${ }^{10}$ Nevertheless, she does briefly sketch the development of activism on campus in the 1970s and 1980s and identifies Salient's place within it. ${ }^{11}$ Hamilton explores these topics in more detail and currently presents the most comprehensive history of Salient that exists. His chapters on the 1960s through to the end of the 1980s gives some sense of what Salient was like as a publication, noting its radical and at times controversial

\footnotetext{
7 Jasmine A. Freemantle, “Constructing Queer in Student Media: Representations of Non-Heterosexuals and NonHeterosexuality in Salient, 1938-2003" (Honours Dissertation, Victoria University of Wellington, 2005), p.32.

${ }^{8}$ Freemantle, pp.2, 12.

${ }^{9}$ Sam Elworthy, Ritual Song of Defiance: A Social History of Students at the University of Otago (Dunedin: Otago University Students' Association, 1990); Alison Clarke, Otago: 150 Years of New Zealand's First University (Dunedin: Otago University Press, 2018); Fay Hercock, A Democratic Minority: A Centennial History of the Auckland University Students' Association (Auckland: Auckland University Press, 1994); Keith Sinclair, A History of the University of Auckland, 1883-1983 (Auckland: Auckland University Press, 1983); Jean Sharfe, Players, Protesters and Politicians: A History of the University of Canterbury Students' Association (Christchurch: Clerestory Press, 1995); Noeline Alcorn, Ko Te Tangata: A History of the University of Waikato: The First Fifty Years (Wellington: Steele Roberts Aotearoa, 2014); Michael Belgrave, From Empire's Servant to Global Citizen: A History of Massey University (Auckland: Massey University Press, 2016).

${ }^{10}$ Barrowman, Victoria University of Wellington 1899-1999: A History, p.9.

${ }^{11}$ Barrowman, pp.341-2.
} 
tendencies in the 1970 s and its coverage of some of the major protest issues of that era. ${ }^{12}$ His history has less to say about Salient in the 1980s, noting the occasional points of tension which emerged between the publication and VUWSA, as well as profiling some of its staff. Hamilton's use of Salient ultimately serves his writing of a history of VUWSA, treating Salient for the most part as an historical source and a reflection of VUWSA policy rather than a publication with its own autonomy and priorities. The two are certainly closely connected. Salient dedicated a lot of coverage to reporting the developments of VUWSA policy and student politics generally. However, many of Salient's areas of reporting had little to do with the Association and often reflected the politics and interests of its editors and current events. To see Salient as simply one articulation of VUWSA's activities precludes a closer examination of how it operated as a publication in its own right. Overall, Barrowman and Hamilton provide brief but useful starting points to conduct a more in-depth study of Salient. Both discuss the general tenor of its reporting and its role within the university. Their histories are also useful as reference works, providing crucial context of what was occurring within the university and the students' association to which Salient was inextricably connected. This thesis builds on the details Barrowman and Hamilton have provided. Rather than being a footnote in the top-down institutional histories of VUW, this thesis investigates Salient on its own terms, coming at it from the bottom up.

As was the case for VUW, most histories of universities in New Zealand were written to mark milestones of a particular university, such as half-centenary and centenary anniversaries. Michael Belgrave's 2016 history of Massey University applies a more critical approach with attention to context. He notes that many histories of universities are "compendiums of the driest details of buildings, disciplines and departments, faculties and fundraising" while others "have tended to be surveys rather than critical explorations". ${ }^{13}$ His intention was to write "an historian's history", placing Massey University in context, tracing its beginnings as a small agricultural college largely founded to serve New Zealand's economic relationship with Britain to a multicampus national university offering qualifications in a wide range of disciplines. His history is

\footnotetext{
12 Stephen Hamilton, A Radical Tradition: A History of the Victoria University of Wellington Students' Association 1899-1999 (Wellington: Victoria University of Wellington Students' Association and Steele Roberts Publishers, 2002), pp.123-98.

${ }^{13}$ Belgrave, From Empire's Servant to Global Citizen: A History of Massey University, pp.10, 497.
} 
"deliberately top-down and big-picture", focusing on the institution. He hopes the inevitable omissions will "inspire future micro-histories". ${ }^{14}$

Rising to this challenge, this thesis analyses how Salient reflected upon VUW, government education policies and developments in tertiary education, but it does so from a bottom up, studentled position, investigating the ways in which Salient interpreted the significance of these developments and responded to them. It also considers the ways in which Salient operated as a publication through which protest could be organised and reported upon, and how it carried political content existing independently of VUWSA policy. It argues student media such as Salient should be viewed within the alternative print media of the 1970s and 1980s. Salient had a great amount of independence and so it is appropriate to consider it through this lens.

The importance of print media as an organisational tool for mobilising political activity is well understood. Alternative, radical, and underground publications have historically been a key means by which protest has been organised. In defining what kind of publication Salient is this thesis uses "alternative media" and "alternative publication" as broad terms, following Chris Atton's definitions. He does not specifically consider student media within his definition of alternative media. His definition does however intentionally allow for a wide variety of different kinds of publications with different audiences and areas of interest to be considered "alternative". ${ }^{15}$ Atton suggests that opposition to mainstream media convention is one element of what makes a publication "alternative" but is not on its own a sufficient defining characteristic. ${ }^{16}$ To this end, Atton proposes that it is a publication's methods of production and the involvement of grass-roots contributors, over and above its content, which defines it as alternative. Alternative publications are "produced by the same people whose concerns they represent, from a position of engagement and direct participation ... they are able to enact social change through their own means of production, which are themselves positioned in relation to the dominant means of production". ${ }^{17}$ This definition, in its synthesis of content and production methods, can be readily applied to Salient. As Chapter One will explore in depth, Salient was largely an amateur operation, reliant on volunteers, which positioned it in opposition to mainstream media convention. Its content reflected the interests and preoccupations of students willing to volunteer

\footnotetext{
${ }^{14}$ Belgrave, p.15.

${ }^{15}$ Chris Atton, Alternative Media (London: Sage, 2002), p.8.

${ }^{16}$ Atton, p.14.

${ }^{17}$ Atton, pp.15-16, 18.
} 
their time to produce the paper, as well as the political views of its editors and the organisations they were involved in.

Relevant studies of alternative publications in New Zealand include Megan Simpson's Master's Thesis on the Resistance Bookshops in Auckland, Christchurch and Wellington in the 1970s, and the work of Toby Boraman. Simpson explores the ways in which the Resistance Bookshops attempted, with varying degrees of success, to act as "radical spaces", where leftist groups of all hues could congregate to plan and discuss political activity. ${ }^{18}$ As bookshops, they also stocked alternative publications from local and overseas publishers which were "unavailable in mainstream stores; this material was often declared radical or subversive due to its unconventional or challenging content". These included books and semi-regular alternative periodicals which were controversial, radical, or counter-cultural. They also sold and distributed more ephemeral print material such as pamphlets and leaflets, even producing some of this material themselves. ${ }^{19}$ Her thesis highlights the role that print played in organising protest action, and in educating and radicalising those involved in protest and counter-cultural movements. She briefly touches on Salient, but does not explore its position within alternative print culture in Wellington in depth.

Boraman has written about leftist publications in New Zealand from the 1970s onwards, writing that they are "inextricably linked to the ebb and flow of struggle in society". ${ }^{20} \mathrm{He}$ canvasses some of the developments and characteristics of this print culture as it existed in New Zealand. Student media is not considered in Boraman's assessment, but he does present a useful theoretical vocabulary for interpreting Salient within the broader alternative print landscape of New Zealand. He draws a distinction between publications with intentions to initiate and report on activism and those with an intellectual bent which attempted to advance the theory of leftist thought and action. He argues convincingly that the latter were less developed in New Zealand than overseas. ${ }^{21}$ Interpreting Salient as an important part of the radical and alternative press in the 1970s and 1980s, the question arises: does Salient fit an activist or theoretical function within Boraman's analysis? Broadly, this thesis argues it served mostly activist aims, but this answer is

\footnotetext{
${ }_{18}$ Megan Simpson, “Radical Spaces: New Zealand's Resistance Bookshops, 1969-1977" (MA Thesis, Victoria University of Wellington, 2007), pp.45-6.

${ }^{19}$ Simpson, p.47.

${ }^{20}$ Toby Boraman, "The Independent Left Press and the Rise and Fall of Mass Dissent in Aotearoa since the 1970s," Counterfutures Vol. 1 (2016): p.31.

${ }^{21}$ Boraman, pp.33-4.
} 
complicated by the nature of Salient's ever-changing staff. The Salient of the early 1970s was different to that of the late 1980s because it was managed by different people, with different politics, writing into different political and social moments. However, Boraman's activist/theoretical distinction is not rigid. He acknowledges that some publications published both kinds of content. The individual politics of the editors and contributors differed across the years, and the issues Salient's contributors addressed changed and developed. As such, while Salient during the 1970s and 1980s took a left-leaning political direction in the main, the precise nature of its political content defies a simple characterisation. For example, in the early 1970s, socialist writers such as Terry Auld delivered informed analysis of overseas politics and attempted to apply the theories of socialism to the conditions in New Zealand. During the 1981 Springbok tour, with Stephen A'Court at the helm, Salient took on more of an activist role. It was a major focal point of activism, providing extensive news coverage of the events of the tour and keeping students informed of when, where, and how they could get involved in anti-tour protests.

The importance of students and university campuses to protest movements is often noted in histories of the socially and politically tumultuous later 1960s, 1970s and 1980s, but the campus newspapers of New Zealand's universities are relatively overlooked as publications which contributed to the print and protest culture of that time period. As general histories of New Zealand note, this was a period of political protest encompassing a wide variety of political issues. $^{22}$ Other histories investigate specific political movements within this wider milieu. Opposition to the Vietnam War, action against sporting contact with apartheid South Africa, Women's Liberation, homosexual rights and liberation, Māori land rights and revitalisation, the anti-nuclear movement, and environmental protection campaigns have all been the subject of

\footnotetext{
22 James Belich, Paradise Reforged: A History of the New Zealanders From the 1880s to the Year 2000 (Auckland: Penguin Books, 2001), p.516; Jock Phillips, “Generations 1965-1984," in Frontier of Dreams: The Story of New Zealand, ed. Bronwyn Dalley and Gavin McLean (Auckland: Hodder Moa Beckett, 2005), pp.337-63.
} 
histories. ${ }^{23}$ Due to issues of space and scope, not all of these movements are explored in-depth in this thesis, but all were reported on in Salient. This thesis highlights the role Salient, as an alternative and political publication, played in supporting, organising, and reporting on these kinds of issues.

This thesis also contributes to the history of the communist and socialist left in New Zealand. There is a lack of historical writing on this topic. Ron Smith's autobiography provides an account of his involvement in the Communist Party of New Zealand (CPNZ) and the Workers' Communist League (WCL) and how his communism influenced his lifelong work in trade unions. ${ }^{24}$ Sue Bradford's biography likewise illustrates some of the rise and fall of the WCL, and Bradford's involvement in wider radical circles. ${ }^{25}$ The involvement of young university students in the uptake of Maoist ideas has received some attention. Maude Anne Bracke describes how young activists around the Western world were energised by the immediacy of Maoist theory and practice as compared to the bureaucracy of the USSR. Maoist youth had a "fierce desire ... to create a rupture with the past". ${ }^{26}$ Alistair Shaw's thesis picks up the influence of Maoism more specifically in the New Zealand context, looking at connections between leftists in New Zealand and their relationships and perceptions of the People's Republic of China. ${ }^{27}$ Shaw acknowledges the significant student membership of the Wellington Marxist-Leninist Organisation (MILO), a Maoist-aligned group formed in 1973 which later became the WCL. ${ }^{28}$ Cybèle Locke notes the presence of WCL members on the VUWSA Executive in the early 1980s and Stephen Hamilton briefly notes that Salient's editors in 1973 were influenced by Maoist ideas, but does not capture

\footnotetext{
${ }^{23}$ A selection of these kinds of histories include: Roberto Rabel, New Zealand and the Vietnam War: Politics and Diplomacy (Auckland: Auckland University Press, 2005); Trevor Richards, Dancing on Our Bones: New Zealand, South Africa, Rugby and Racism (Wellington: Bridget Williams Books, 1999); Christine Dann, Up From Under: Women and Liberation in New Zealand 1970-1985 (Wellington: Bridget Williams Books, 1985); Chris Brickell, Mates and Lovers: A History of Gay New Zealand (Auckland: Godwit, 2008); Aroha Harris, Hikoi: Forty Years of Maori Protest (Wellington: Huia Publishers, 2004); Elsie Locke, Peace People: A History of Peace Activities in New Zealand (Christchurch: Hazard Press, 1992); Maire Leadbeater, Peace, Power \& Politics: How New Zealand Became Nuclear Free (Dunedin: Otago University Press, 2013); David Young, Our Islands, Our Selves: A History of Conservation in New Zealand (Dunedin: Otago University Press, 2004).

${ }^{24}$ Ron Smith, Working Class Son: My Fight Against Capitalism and War (Wellington: Ron Smith, 1994).

${ }^{25}$ Sue Chamberlain, Constant Radical: The Life and Times of Sue Bradford (Masterton: Fraser Books, 2017).

${ }^{26}$ Maud Anne Bracke, "The 'Spirit of 1968': Cultural Revolution," in The Oxford Handbook of the History of Communism, ed. S.A. Smith (Oxford: Oxford University Press, 2014), p.167.

${ }^{27}$ Alistair Shaw, "Telling the Truth About People's China"” (PhD Thesis, Victoria University of Wellington, 2010), p.5.

${ }^{28}$ Smith, Working Class Son, pp.162-3.
} 
the longevity or extent of that influence. ${ }^{29}$ This thesis expands on these works, demonstrating in more detail Salient's connections to the communist left through MILO and the WCL that were close and enduring in the 1970s and early 1980s, before waning throughout the 1980s.

Salient's connection to the communist and socialist left in New Zealand also facilitated involvement in Wellington trade unions. Locke's in-depth study of union members and activists from the bottom-up provides an account of the developments and the struggles of the trade union movement across the time period this thesis considers. ${ }^{30}$ Ryan Bodman's work is useful not only for its explanation of the maligning of unions in the 1970s and 1980s, but also for its cogent discussion of the myth of objectivity in the mainstream media against which Salient positioned itself. $^{31}$ In addition to his study of leftist publications, much of Boraman's work has proved illuminating in its articulation of different strands of leftist thought and action in New Zealand. These include his exploration of the emergence of "New Left" groups and generational conflict with "Old Left" groups such as the CPNZ, and his work on the contested legacy of the events of 1968 in New Zealand and overseas. ${ }^{32}$ His work provides key context regarding the development of left-wing groups in New Zealand to which Salient responded and was involved in. Regarding unions and students, my work expands on his demonstration of attempts to engender connections between students and trade unions in the 1960s and 1970, looking at how this form of solidarity was developed in Salient. ${ }^{33}$

The body of literature canvassed here provides important historical context to understanding Salient. However, this thesis seeks to demonstrate that Salient and its contributors were involved in a wide array of political action, often in ways and to an extent which is not captured within this historical literature, if at all. This research is novel in the way it centres the analysis and reporting of a student publication which looked out and observed, analysed, and was

\footnotetext{
${ }^{29}$ Cybèle Locke, "Maori Sovereignty, Black Feminism, and the New Zealand Trade Union Movement," in Indigenous Women and Work: From Labor to Activism (Chicago: University of Illinois Press, 2012), p.264; Hamilton, A Radical Tradition, pp.162-3.

${ }^{30}$ Cybèle Locke, Workers in the Margins: Union Radicals in Post-War New Zealand (Wellington: Bridget Williams Books, 2012).

${ }^{31}$ Ryan Bodman, "'The Public Have Had a Gutsful and So Have We': The Alienation of Organised Labour in New Zealand, 1968-1984" (Master's Thesis, University of Auckland, 2013).

32 Toby Boraman, "The New Left in New Zealand," in On the Left: Essays on Socialism in New Zealand, ed. Pat Maloney and Kerry Taylor (Dunedin: Otago University Press, 2002), pp.117-32; Toby Boraman, "Revisiting the Global and Local Upheavals of 1968," Counterfutures Vol. 6 (2018): pp.36-67.

33 Toby Boraman, "A Middle-Class Diversion from Working-Class Struggle? The New Zealand New Left from the Mid-1950s to the Mid-1970s," Labour History Vol. 103 (November 2012): pp.203-226.
} 
involved in political activity over a significant period of time. In doing so, I hope to generate greater consideration of the historical influence of student newspapers in New Zealand.

\section{Oral History}

As part of this research project, I conducted six oral history interviews with people who were involved in Salient. I interviewed five former editors: Roger Steele (1973 and 1974), Peter Franks (1973), Simon Wilson (1978), Mark Cubey (1983), and Jane Hurley (1985). I also interviewed one regular early 1980s contributor and former member of VUWSA, Margie Thomson. John Ryall (Salient editor in 1976) and Robert Reid (a fellow traveller and contemporary of many of Salient's editors) also kindly allowed me the use of their oral interviews, conducted by my supervisor, Cybèle Locke. The rationale behind using oral history for this project was to get beyond the pages of Salient to contextualise what kinds of personal and exterior influences were present in the Salient office. In writing a history of Salient from below, the voices of those who formerly created and shaped the paper had much to offer this research.

Alessandro Portelli, in conceptualising the different uses of written and oral historical sources, writes that they have "common as well as autonomous characteristics, and specific functions which only either one can fill ... [Oral history] tells us less about events than about their meaning ... Oral sources tell us not just what people did, but what they wanted to do, what they believed they were doing, and what they now think they did". 34 These ideas first prompted my interest in pursuing oral history for this project. As a record of events and analysis of those events, the volumes of Salient present a complete, extant body of work. I wanted to see what memories and impressions Salient's editors and contributors had of creating that record, and how that might enrich Salient content, aiding my understanding of why Salient reported on the things it did in the manner it did.

These interviews proved crucial to the project, influencing its final form in ways both big and small. Interviewees often could not recall specific details of articles, relationships, areas of reporting, or events, but could recall the way they responded at the time, give some sense of their significance, and reflect on those reactions. Meanwhile, the specifics of these events were for the most part available in Salient itself. This allowed me to consider the meaning attached to an event

\footnotetext{
${ }^{34}$ Alessandro Portelli, "What Makes Oral History Different," in The Oral History Reader: Third Edition, ed. Robert Perks and Alistair Thomson (New York: Routledge, 2016), pp.49, 51.
} 
in synthesis with the specific details presented in articles which responded to that event. The result was, as Portelli describes, a satisfying synthesis of oral and written sources which together provide a more nuanced account of Salient than either could provide on their own. Interviews also provided insights into the origins of political analysis in the newspaper. Salient's editorials and intentionally subjective reporting gives a good sense of what its editors and contributors believed. What is not always as clear is where those opinions originated, and what external groups, relationships, or personal experiences were informing the content of Salient. Interviewees were able to articulate what was informing their political views; in turn, I was then able to consider how this was manifested in Salient, shedding new light on the significance of particular strands of reporting.

Furthermore, these interviews allowed me to consider how interviewees' political views had changed over time. A common theme was youthful idealism - opinions passionately argued and vigorously held in Salient were, upon reflection, cast as a symptom of figuring out one's personal politics during a period of self-discovery. Thomson for example expressed some embarrassment at how "polemical" her political writing in Salient had been; Franks spoke about being in his early twenties and being informed by a wide array of political ideas; and Steele felt he has never had a definable political ideology, but did express some regrets about the tenor of his writing in Salient. ${ }^{35}$ These kinds of memories gave insights into why Salient was how it was, alongside reflections of what it might have been and perspectives on what might be done differently now. As Boraman notes, leftist publications "often do not capture the complexity, energy and spirit of struggles ... nonetheless they can reveal important trends within movements". ${ }^{36}$ Salient on its own captures much of the activity of its editors and contributors, but it could never capture everything. Oral interviews helped to fill in some of these gaps, and to get at the meanings Salient had to those who made it. The contributions of my interviewees greatly improved this thesis.

\section{Methodology}

This project draws heavily on back issues of Salient as its primary source base. This involved a thorough survey of the time period, drawing out patterns of reporting, themes of

\footnotetext{
${ }^{35}$ Margie Thomson, interviewed by Max Nichol 9 December 2018; Peter Franks, interviewed by Max Nichol, 20 December 2018; Roger Steele, interviewed by Max Nichol, 16 December 2018.

${ }^{36}$ Boraman, "The Independent Left Press and the Rise and Fall of Mass Dissent in Aotearoa since the 1970 s," p.33.
} 
reporting, and exploring how these are affected across time as the contemporary context shifts, and by the individuals who edited Salient. Conducting research into the content of a regularly produced publication presents an issue of having to engage with an unassailable volume of primary material. In order to discuss both the 1970s and 1980s within the time constraints of a twelvemonth thesis project, it proved necessary to employ a sampling process to cut down the volume of primary material to be analysed. In simple terms, I did not have the time to read then adequately analyse every single issue of Salient. To carry out a reliable sample necessitated a robust process which was justifiable based on reliable methods of sampling qualitative data and content analysis. Fundamentally, I needed to be confident that my sample would be sufficiently reliable that the findings and conclusions of the thesis would not be drastically different to those I would have reached had I read every single issue. To do so required drawing on elements of the methodology of content analysis. Content analysis provides a vocabulary and sound methodological basis for historians of print publications looking to use some form of statistical sampling in their research.

To conduct my survey of Salient, I drew on the work of Stephen Lacy, Kay Robinson, and Daniel Riffe Drager, who all have addressed methods of sampling weekly publications. They sought to establish how many issues of a weekly publication one must sample in order to achieve a sufficiently representative sample of that publication's content. Their results showed that fourteen issues out fifty-two issues provide a reliable representation of the year's content. ${ }^{37}$ Applying this ratio to Salient, which generally had a yearly run of twenty-four issues with only minor deviations, suggests that six issues per year should provide a reliable representation of the kinds of issues Salient covered. I used a systematic sample, meaning that every fourth issue of Salient was sampled to achieve six issues per year. ${ }^{38}$ Every single editorial from each issue was included in the sample as well. Not every issue of Salient had an editorial. Some editors never missed an issue, others were much less prolific. By sampling every editorial where one was available, I was able to take a census of editorial writing in Salient throughout the period. As the editorials frequently contained information relating to the direction and creation of Salient itself,

\footnotetext{
${ }^{37}$ Stephen Lacy, Kay Robinson, and Daniel Riffe, "Sample Size in Content Analysis of Weekly Newspapers," Journalism and Mass Communication Quarterly Vol. 72, no. No. 2 (Summer 1995): p.343.

38 This is one of a number of ways to sample qualitative information within the methodology of content analysis. Based on time, ease of execution, and reliability, I deemed a systematic sample was most appropriate. For more information see Klaus Krippendorff, Content Analysis: An Introduction to Its Methodology, Third Edition (Thousand Oaks: SAGE Publications, 2013).
} 
these were particularly important to capture. It also ensured that at least one article from (almost) every issue was included in the database.

Not every article from every issue was included in the sample. This was to save on time while producing a dataset of articles which could best answer the questions of this research. Specifically, reviews were not sampled. Salient carried a significant number of reviews of books, films, local theatre, art installations, and restaurants throughout the 1970s and 1980s. Leaving these out of the dataset under consideration for this project was not to discount this function of Salient, but rather to specify the content gathered in relation to the research questions. As this thesis is primarily concerned with the political content of Salient and the production of the paper, the content of reviews would have been extraneous to these purposes. Of course, much art is inherently political, responding to or commenting on contemporary political discourse. By the same token, responses to art can be taken as political commentary. Indeed, Salient's reviews often took a political position, criticising the representations of particular issues or noting the conspicuous absence of politics in artistic texts. ${ }^{39}$ Ultimately however, I felt that including reviews and arts reporting would not sufficiently enrich or illuminate the answers to the questions this thesis poses to justify the additional workload. Accordingly, there is little discussion of Salient's involvement in the Wellington arts scene. Suffice it to say here that this was a reasonably significant area of Salient's operations, but it has not been considered in this thesis.

This sampling process produced a database of over 2000 Salient articles from across the seventeen years, which were categorised by their content. I also took research notes on each article for more specific information about its contents. This proved an invaluable reference while writing the thesis, allowing for articles to be easily grouped by year and by the same or similar topics. This does not mean that the articles which were not included in the sample were totally discounted. Throughout my survey of Salient issues, articles which at face value appeared to be useful for the research were briefly noted in a separate document. Likewise, once the sampling process was complete and I began writing, it was often the case that an article in the database would be a part of a series of reporting. Finding the other articles in such a series provided further context to what was already captured in the database.

\footnotetext{
${ }^{39}$ Bruce Robinson, 'Editorial: Criticising the Critics', Salient, Vol. 38, No. 9, 29 April 1975, p.2.; Simon Wilson, interviewed by Max Nichol, 8 December 2018.
} 
This thesis is arranged into three chapters. Chapter One takes a broad view of Salient across the 1970s and 1980s, providing context for its production, relationship to its audience, and position within the print media landscape of the time. I argue that it sits within the alternative print culture of the time period. The chapter also explores the nature of Salient's relationship to its primary readership: students at VUW. The tension between where Salient's editors wanted to take the paper politically and the expectations of the students who ultimately funded Salient is explored.

Chapter Two examines the "long 1970s", a periodisation which encompasses the uptick in protest in the late 1960s through to the anti-Springbok Tour movement of 1981. Salient took a consistently socialist line of analysis during this time period, and maintained support for and close connections with trade unions. Salient's editors and staff deployed the paper as an extension of their involvement in a vibrant period of multi-issue political activism.

Chapter Three examines the 1980s. Salient moved away from its socialist line of analysis, though remained broadly left-wing, generally pushing support for progressive causes. In the second half of the 1980s however, the threat of "user pays" tertiary education forced Salient to contend with the politics of education to a greater degree than it had in the past. Other political issues, while present, were pushed to the periphery as reporting on education policy and the organisation of protest against this policy came to dominate the pages of Salient. 


\section{Chapter One "SALI 101": An Overview of the Production and Print Context of Salient}

Little work has been done to define the form, function, and influence of student media in the history of print culture in New Zealand. In the institutional histories of students' associations and universities, student media publications are defined by their relationships to their constituent associations. Articles from the record of publications like Salient are deployed as sources to illustrate developments in association policy and the activities of the association. Certainly, this was an important part of Salient's function. But Salient's content and editorial direction went beyond this, offering coverage of political and social issues in New Zealand and overseas. This chapter seeks to provide the contextual background of the working conditions of Salient's production, examining the culture of the Salient offices to give a sense of how Salient was actually created each week. It also explores Salient's accountabilities to students and VUWSA, and how its editorial independence could conflict with the expectations of the students who funded its existence. From there, I will look wider to the print media of New Zealand, examining Salient's opposition to the mainstream media notion of journalistic objectivity. Salient tended to reject objectivity as a realistic foundation for journalism, which prompted accusations that Salient was biased. Discussions about who had access to Salient, who Salient "belonged" to, and editors' attitudes to what political views should be included and excluded then ensued. I argue that because Salient's editors took advantage of its editorial independence and rejected mainstream journalistic convention, Salient can be seen as an alternative print publication over and above its function as a student newspaper. Salient shared similarities and challenges with other alternative publications in Wellington in the 1970s and 1980s, particularly with regards to the law. Yet in contrast to many alternative publications, Salient was more consistently published, more financially secure, and potentially more widely read.

Salient existed within a hierarchy of student political bodies, both on the Victoria University of Wellington (VUW) campus and nationally. Salient was accountable to the Publications Board, a sub-committee of the Victoria University of Wellington Students' Association (VUWSA) which managed funds and appointed editors for the various publications for which VUWSA was publisher: Salient, the capping magazine Cappicade, and the annual 
VUWSA Student Handbook, a volume published at the start of each year for Orientation Week. Salient also liaised with the Publications Officer which was a VUWSA position elected by the student body. ${ }^{1}$ In turn, VUWSA was incorporated with two other student political bodies, the Student Representative Council (SRC) and the New Zealand Union of Students' Associations (NZUSA). The SRC, first convened in 1968, was the policy-making arm of VUWSA. Inspired by the fervour of student protest and organisation overseas, it was designed to encourage participatory democracy. Every VUWSA member had the right to attend SRC meetings, held regularly throughout the academic year, and propose, debate, and vote on whether motions should become association policy. According to Stephen Hamilton, SRC achieved its intended effect of slowly but surely "diluting the power base of the male (mostly law) students who had dominated the executive ... since its founding 70 years ago." 2 The VUWSA Executive was unable to create policy on its own - it could only adhere to the policy created by SRC, providing the personnel and the funds required to put SRC policy into effect.

The NZUSA was the national body of university students. It existed to be a pressure group on behalf of all university students from its seven federated Students' Associations, those of Victoria, Auckland, Otago, Canterbury, Lincoln, Massey, and Waikato. VUWSA's delegates to NZUSA Council meetings, held biannually during the May and August university breaks, were elected by SRC and were likewise bound to act consistently with SRC policy when voting on NZUSA policy. The National Executive of NZUSA was based in Wellington. It is worth noting that other forms of tertiary education, namely teachers' colleges and technical institutions, had their own federated national student bodies. ${ }^{3}$

Salient was primarily funded by VUWSA, supplemented by income from advertising and the operation of a commercial typesetting business, which used Salient equipment. Of the VUWSA fees charged to every member at the start of each year, a certain amount was set aside for student media. In 1981 for example, the association fee was set at $\$ 51$, of which $\$ 4.50$ went to the

\footnotetext{
${ }^{1}$ This position was later renamed the Media Officer, to reflect the introduction of VUWSA's student radio station, Radio Active.

2 Hamilton, A Radical Tradition, p.127.

${ }^{3}$ Gyles Beckford, 'NUS - or not to NUS', Salient, Vol. 39, No. 12, 7 June 1976, pp.4-5. In 1976 there was some suggestion that these bodies should combine to form a pan-tertiary National Union of Students, the model of national student representation in Australia, but this did not come to pass.
} 
Publications Board to pay for Salient, Cappicade, and the VUWSA Student Handbook. ${ }^{4}$ Although Salient was funded and published by VUWSA, an important part of their relationship was that Salient had editorial independence from the Association. Salient was also partly financed by advertising, sold by the Publications Board business manager. The Bank of New Zealand, which had a branch on campus, was one of the most consistent advertisers across the 1970s and 1980s, but other banks, large companies, local businesses, cafes, and restaurants also took out ads in Salient.

Salient operated its commercial typesetting service from the late 1970s. The typesetting service was not a hugely lucrative business, but did add to the Salient coffers through steady work. It offered cheaper rates than were available elsewhere. The advertising for the service in Salient emphasised the breadth of publications suitable for their setup and promised to match "the quality and speed of ... any downtown operation" at a significantly reduced cost. They also offered discounts to students, student groups, and not-for-profits. ${ }^{5}$ Their clients were an eclectic mix of government departments, Wellington activists, and small Wellington serials. For activists needing leaflets or publications typset, the appeal of going through the Salient offices was simple: "We were cheap and friendly". ${ }^{6}$ Following ongoing issues with Salient's typesetting machine, VUWSA stumped up the $\$ 6000$ needed to finance a new machine in June 1985 . While this required the Publications Board to run at a $\$ 5000$ deficit for the year, the Association also believed it would mean Salient could handle more typesetting clients. Salient received a slight funding bump in the VUWSA budget for 1986, but less than the Publications Board had requested due to the belief that with the new machine, commercial typesetting could help make up the difference. ${ }^{7}$

Typically, Salient's editor changed every year - only on a few occasions in the publication's history has an editor served for two years in a row. The position was advertised and filled towards the end of each academic year. The hiring process was the responsibility of the

\footnotetext{
4 'Victoria University of Wellington Students Association Budget 1981', Salient, Vol. 44, No. 21, 8 June 1981 , p.11. Radio Active, the student radio station which operated from 1977, was administered by the Radio Board. In 1981, $\$ 0.80$ from every student's fees were set aside for the running of the Radio Board.

${ }^{5}$ Stephen A'Court, 'Typsetting', Salient, Vol. 45, No. 7, 19 April 1982, p.5.

${ }^{6}$ Margie Thomson, interviewed by Max Nichol, 9 December 2018. Likely the most auspicious contract that passed over the desk of the service was with the Spiral Press, who commissioned it to typeset the manuscript of Keri Hulme's The Bone People, which won the Man Booker Prize in 1985.

7 'The 1986 Budget', Salient, Vol. 48, No. 24, 30 September 1985, p.6.
} 
Publications Board. ${ }^{8}$ Those who sat on the Publications Board were a mix of Salient employees and representatives from VUWSA and SRC. In 1986 for example, the Publications Board consisted of Richard Adams as Salient editor, Andrew Little as Business Manager, Dean Bedford as Media Officer, Olwyn Crutchley as the nominee of the Finance Officer (a VUWSA Executive position), and SRC representatives Karolyn Porter, Wayne Eagleson, Steve Cosgrove, Chris Ellis and M. Webster. ${ }^{9}$ The editor position was not particularly well paid. The advertisement for Salient's editor for 1979 put the editor's salary at $\$ 42$ per week, from " 2 weeks before the first issue to 1 week after the last". ${ }^{10}$ The construction of the paper also tended to demand far more than a forty hour work week. Throughout the 1970s and 1980s, Wanganui Newspapers was Salient's printer. The final copy of each issue of Salient had to be completed by approximately midnight on a Friday to be handed over to the overnight bus driver to Whanganui. When the creation of the paper came down to the wire - and this was often - a staffer would execute a mad dash from the Salient offices, clutching the fully constructed copy of Salient as they ran down Mount Street, along The Terrace, and onto Boulcott Street where the bus would be waiting outside the Dominion offices. On occasion, editor Mark Cubey even resorted to foregoing the bus and putting the week's Salient on the morning plane to Whanganui, buying him a few extra hours. ${ }^{11}$

Despite the difficulty and stress, past editors and contributors interviewed for this project emphasised how much they enjoyed working for Salient and the community which revolved around it. The physical space of the Salient offices and the culture it generated is an important part of understanding why. The offices were located on the ground floor of the Student Union building, with a dark room for developing photos, a small kitchen, an open-plan office for reporters, and a private office for the editor. It was a messy, chaotic space, littered with scraps of paper and glue from cutting and pasting up the paper. ${ }^{12}$ The air was often thick with cigarette smoke - Cubey recalled that just about everyone smoked. One Salient reporter invoked the cliché of a smoke-filled newsroom, writing that "there is a large degree of truth in that image" and claiming to "smoke six packets of cigarettes [every week]. Most of them while I'm thumping away on old Imperial 66

\footnotetext{
${ }^{8}$ A technical editor was also usually appointed, though some editors performed this role themselves. The technical editor was chiefly responsible for the design and layout of the paper, in consultation with the editor.

9 'Salient Editor Told Resign Or Else', Salient, Vol. 49, No. 22, 22 September 1986, p.3.

10 'Salient 1979', Salient, Vol. 41, No. 21, 28 August 1978, p.17.

${ }^{11}$ Mark Cubey, interviewed by Max Nichol, 5 December 2018.

12 Mark Cubey, interviewed by Max Nichol, 5 December 2018.
} 
typewriters". ${ }^{13}$ Editor Jane Hurley wrote similarly that that "you come in on a Monday morning right? [A]nd the stale tobacco smoke hits you like the blocking heat from a fired furnace. Some of us stagger back. Some of the staff need that smoke". ${ }^{14}$

General detritus and stale smoke aside, the Salient office was a social space in addition to its role as the engine room of the paper's production. It was abuzz with staff, contributors, activists, artists, and students coming and going. Many were there to chip in to the paper's creation but others were just there to see their friends and hang out. As Margie Thomson recalled, "there was one of those great big tins of Nescafe instant coffee ... you'd have maybe fifteen cups of coffee a day ... what else did you need in life? Nothing, really, that was where your friends were, you'd have coffee, you'd sit around". ${ }^{15}$ The sentimental, nostalgic significance of the Salient offices was made evident when they were re-floored in 1987. Pieces of the "tastefull off-creme/brown linoleum [sic]", worn down by the "constant pacing of scheming anarchists" and "commie pinkos" were sold as souvenirs. ${ }^{16}$ Salient's contributors were young, idealistic, and given the keys to a platform with a large readership. Involvement with Salient meant being a part of a community with a common goal to put out the best paper possible from week to week. In simple terms, working for Salient was a challenging but exciting opportunity. It fostered a community, the centre of which was the Salient office.

Salient was primarily reliant on students volunteering their time for most of its operations. Cubey and Roger Steele recalled that there was a certain amount of petty cash available, some of which might be doled out to contributors who had given a lot of their time in a particular week to Salient. However, these sums were nominal, a token of appreciation. ${ }^{17}$ Only the editor, technical editor, business manager, and typesetter were paid anything which approached proper compensation. Much of Salient's content, as well its construction, was contributed by volunteers. Workshops on journalism and the technical aspects of creating newspapers were a means of

\footnotetext{
${ }^{13}$ Paul Wiggins, 'Reporting', Salient, Vol. 47, No. 22, 17 September 1984, p.9.

14 Jane Hurley, 'Editorial', Salient, Vol. 48, No. 13, 17 June 1985, p.2.

15 Margie Thomson, interviewed by Max Nichol, 9 December 2018. Though many were there for the friendly environment, some students would come in for the sole purpose of having a go at the editor for printing something they disagreed with, or for not writing about something they felt should have been covered. Bruce Robinson, 'Editorial', Salient, Vol. 38, No. 21, 4 September 1975, p.2; Sally Zwartz, 'How It's All Done', Salient, Vol. 47, No. 22, 17 September 1984, p.1.

16 'Salient Floored', Salient, Vol. 50, No. 6, 13 April 1987, p.3.

${ }^{17}$ Mark Cubey, interviewed by Max Nichol, 5 December 2018; Roger Steele, interviewed by Max Nichol, 16 December 2018.
} 
recruiting students to contribute this time and train them in the necessary skills. In 1975, Salient advertised an open day, stating plainly: "WE NEED STAFF. In order to make this newspaper the viable concern it used to be in the good old days of Uncle Roger, we are mounting a MASSIVE PUBLICITY CAMPAIGN". The open day promised the expertise of early to mid-1970s Salient stalwarts such as Bruce Robinson, Anthony Ward, John Henderson and "lo and behold, PETER FRANKS!"18 The itinerary for the day featured a session on news and review-writing skills, another on "Technical workshops" covering cartooning and newspaper design, and an evening session for staff to discuss what Salient's role should be for the year. ${ }^{19}$ In an advertisement for an open day in 1981, editor Stephen A'Court emphasised that expectations of contributors' time were low: "If you see yourself as a journalist, Salient has a place for you. We welcome anyone with a contribution to make; from a complete article to twenty minutes of proofreading". ${ }^{20}$ In 1983 when Nigel Mander, a consistent contributor in the mid-1980s and VUWSA President in 1988, first walked into the Salient office to offer his help, Cubey set him to work on a pile of dishes. ${ }^{21}$ In the week before the Easter break in 1986, editor Richard Adams ran a workshop advertised as "SALI 101 ", a course which promised to teach students "interested in learning layout and journalism skills".22

These workshops both recruited new contributors and allowed Salient veterans to pass on their skills, ensuring that despite high staff turnover, the technical skills of sub-editing, proofreading, typesetting, and layout design did not have to be rebuilt from scratch each year. ${ }^{23}$ It was common for the editor to take up another skilled position such as typesetter or technical editor in the year following their editorship. Simon Wilson was editor in 1978, and since he had no technical editor he performed this role himself. He then became technical editor in 1979. Likewise, Cubey was technical editor in 1984 following his editorship in 1983. Indeed, the technical side of

\footnotetext{
18 'Salient Notes', Salient, Vol. 38, No. 10, 22 May 1975, p.2.

19 'Salient Open Day Drop In!', Salient, Vol. 38, No. 10, 22 May 1975, p.20.

20 'Salient Open Day: Staff Wanted A Great Deal', Salient, Vol. 44, No. 2, 9 March 1981, p.11.

${ }^{21}$ Mark Cubey, interviewed by Max Nichol, 5 December 2018.

22 'New Course offered! SALI 101', Salient, Vol. 49, No. 3, 17 March 1986, p.3.

${ }^{23}$ The physical process of designing and typesetting the copy to be sent to the printer each week required no small amount of technical skill. Articles needed to be edited, sub-edited, typeset, proof-read, then designed and pasted up before the issue was ready to go to the printer. Prior to 1979, Salient used an IBM "golfball" typesetter, most likely the IBM Selectric which used a single golfball-shaped unit to generate text. The golfball could be swapped out, allowing for the use of different fonts. Salient went digital for its typesetting in 1979, with the purchase of a Compugraphic 4600, which was in turn replaced by an Editwriter 7500 in 1985.
} 
designing and constructing the paper appealed to him more than writing. ${ }^{24}$ Hurley was the typesetter in 1986, having gained experience while doing much of her own typesetting as editor the previous year. Maintaining staff already skilled in some of the technical elements of putting Salient together ensured that Salient was not re-inventing the wheel every year.

Although volunteering their time and learning on the job was how many of Salient's editors gained the skills of writing for and creating Salient, not all were enthusiastic amateurs. John Ryall, editor in 1976, had studied journalism before studying at VUW and in the early 1980s, Salient had a series of editors with prior journalistic experience. ${ }^{25}$ The editors from 1982-84 had all worked in the mainstream media in some capacity. Mark Wilson had been a print journalist prior to working for Salient, Cubey had done a cadetship for the New Zealand Broadcasting Corporation, and Sally Zwartz had studied journalism school and worked as a proof-reader in Australia. ${ }^{26}$ Mark Wilson in particular brought a degree of professionalism to Salient, instructing Salient's reporters on the conventions of good newswriting. ${ }^{27}$ When Cubey became involved in 1982, there was a strong old guard at Salient who trained students who wanted to get involved in the production of the paper. He also credited the technical editorship of Tim Bollinger with lending the paper a distinctive and coherent design direction, in addition to a series of original serialised comics which played out over the course of the early 1980s. ${ }^{28}$

Though it did not necessarily directly influence the content of the paper, it is important to understand how it was produced. As Chris Atton suggests, alternative publications are not just defined by their content, but by their methods of production. He argues that the involvement of grass-roots contributors, producing a publication in circumstances which defy mainstream conventions and methods is a significant part of what defines alternative media. ${ }^{29}$ This was certainly the case for Salient. It was made by students who gave their free time to put the paper together, most of them for little to no pay, working long hours in a dirty office tucked away in the corner of the Student Union building. The community which sprung up around Salient was one of young students trying their hand at journalism and embracing the opportunity to learn new skills

\footnotetext{
${ }^{24}$ Mark Cubey, interviewed by Max Nichol, 5 December 2018.

25 John Ryall, interviewed by Cybèle Locke, 17 December 2014.

${ }^{26}$ Margie Thomson, interviewed by Max Nichol, 9 December 2018; Mark Cubey, interviewed by Max Nichol, 5

December 2018; 'New Salient editor appointed!', Salient, Vol. 46, No. 24, 26 September 1983, p.3.

${ }^{27}$ Margie Thomson, interviewed by Max Nichol, 9 December 2018.

${ }^{28}$ Mark Cubey, interviewed by Max Nichol, 5 December 2018.

${ }^{29}$ Atton, Alternative Media, pp.16-18.
} 
and articulate what was important to them. It was, for the most part, an amateur affair. This was an integral part of its production - as Cubey notes, "if you make stuff too flash and easy then... you lose the grit". 30

\section{Rejecting “Objectivity" and Navigating Student Expectations}

A consistent element of Salient's editorial direction was an opposition to and explicit rejection of the supposed "objectivity" of the mainstream media. This has long been one of the hallmarks of the mainstream media, which trades on its commitment to impartiality and the notion of speaking truth to power. Objectivity in the media is a contested ideal. According to American media historian Mark Brewin, this journalistic tradition has its roots in modernism and the scientific method. It relies on the notion that a set of events can be essentialised to its base elements - facts, statistics, the people involved, and the order events occurred - and that these can be presented without being compromised by the writer's personal point of view. In the post-war period United States, journalists were expected to be impartial seekers of truth, providing facts unblemished by personal or institutional opinion. Objectivity was the default position of newspaper reporters and editors. ${ }^{31}$ Brewin explains that in the 1960s and 1970s, some academics began to question the notion of objectivity within academia. Social scientists and historians considered how seemingly objective "truths" could in fact be the product of dominant values and social categories. ${ }^{32}$ These academics extended their criticism to other important civic institutions, including the media. They levelled that rather than being "disinterested purveyors of truth ... journalists in fact (and probably to some extent unconsciously) had internalized a whole set of conventional attitudes ... which invariably favored the status quo". ${ }^{33}$ In positioning objectivity as central to the journalistic profession, the mass media privileged the values of the dominant culture which were likewise cast as being grounded in objective truth. Despite these criticisms, Brewin concludes there is little evidence that they had any significant effect on the mainstream American press' disposition towards objectivity. ${ }^{34}$

\footnotetext{
${ }^{30}$ Mark Cubey, interviewed by Max Nichol, 5 December 2018.

${ }^{31}$ Mark W. Brewin, "A Short History of the History of Objectivity," The Communication Review Vol. 16, no. 4 (2013): p.214.

32 Brewin, p.215.

33 Brewin, p.216.

${ }^{34}$ Brewin, p.218.
} 
In the New Zealand context, journalist and historian Les Cleveland's 1970 Master's thesis investigated the state of the New Zealand print and broadcast media, and its responsibilities. In a systematic analysis of major New Zealand newspapers and the New Zealand Broadcasting Company, Cleveland concluded that the media held the potential to act as a powerful scrutineer of the government and corporate institutions on behalf of the public. To do so would require the development of the "hallmark of the quality newspaper ... its strong opinions and its interpretative capacities". ${ }^{35}$ However, in his view, few mainstream media outlets were willing to push the boundaries of what was acceptable within the dominant framework of journalistic objectivity, seeing their role as "more recorder and entertainer than expositor and prescriber". ${ }^{36}$ As Brewin notes of the American media in the 1960s and 1970s, much of New Zealand's mainstream media adhered to the guiding principle of objective reporting.

Drawing on the media analysis and theories of Edward S. Herman and Noam Chomsky, Ryan Bodman has demonstrated further how the mainstream print media in New Zealand in the 1970s and 1980s held a self-interested commercial imperative. In the context of trade unionism, he demonstrates how both the government and the major daily newspapers had a stake in the maintenance of capital. In the case of the print media, its reliance on advertising as the primary vehicle of generating revenue meant that when 'economic decline impacted their clients' ability to purchase advertising space, commercial media outlets suffered". ${ }^{37}$ To this end, Bodman argues that during the period from 1968 to 1975 , the mainstream media had a major role in the political and social framing of trade unions. The New Zealand economy stumbled briefly in the late 1960s and took a nosedive in 1973. In a context of economic decline, industrial disputes and strike actions increased markedly during the 1970s and 1980s. ${ }^{38}$ These disruptions posed a threat to the economic conditions upon which daily newspapers relied, and the response from large dailies such as the Press and the New Zealand Herald was to dedicate column inches to castigating the activities of unions.

Initially, the media framed a dichotomy of "responsible" and "militant" unions. Responsible unions that engaged state-supported arbitration systems rather than strikes to settle

\footnotetext{
${ }^{35}$ Les Cleveland, "The Structure and Function of the Press in New Zealand" (MA Thesis, Victoria University of Wellington, 1970), p.215.

${ }^{36}$ Cleveland, p.214.

${ }^{37}$ Ryan Bodman, "'The Public Have Had a Gutsful and So Have We': The Alienation of Organized Labour in New Zealand, 1968-1975," New Zealand Journal of History Vol 48, no. 1 (2014): p.81.

38 Bodman, pp.83-4.
} 
disputes with employers were depicted as being concerned with national economic interests and were lauded for their non-disruptive behaviour. Militant unions, in contrast, were depicted as cynically plying direct action to satisfy the self-interest and greed of its members, to the detriment of the national interest. ${ }^{39}$ These categories became more blurred around 1974 and the media began to tar all unions with the same brush - unions were responsible for undermining the economy. This stoked public sentiment that unions were not wielding their power responsibly and in the public interest. ${ }^{40}$ The mainstream print media had an active role in shaping this view of unions and industrial action. Far from providing neutral reporting of industrial relations as the principle of journalistic objectivity would dictate, Bodman demonstrates that the major daily newspapers had observable self-interested biases due to their reliance on private capital through advertising.

It was this lofty ideal of objective reporting, betrayed by the internal agendas of the mainstream media, which Salient frequently both identified as unrealistic and openly rejected as valuable or necessary to its operations. In 1976 for example, Salient published a series of articles in which the authors picked apart a piece of "objective" reporting from one of the major New Zealand dailies to reveal the attitudes and biases underpinning it. The intention was to show that the Wellington dailies could be just as biased as Salient, but were less willing to be open about it:

Every so often (in fact, most of the time) an avalanche of abuse descents [sic] on Salient. We're accused of being doctrinaire left-wing, thoroughly renegade. One letter, last week, suggested that Salient should be printed in red type and renamed the Peking Periodical or the Moscow Times. There is a clear feeling that we are biased and that we're not giving the 'facts' that the downtown newspapers give, but merely some distorted prejudiced rave. Sure, you'll agree that everyone's slightly biased and the Evening Post, the Dominion, and (heaven forbid) Truth distort a little. But Salient is just too much - or could it be that our bias just doesn't coincide with the prevailing one? ${ }^{41}$

This is one of the most consistent characteristics of Salient as a publication. Every single editor of Salient in the time period under consideration at some stage articulated their belief in this distinction between Salient and the mainstream press. For a typical example, in 1978 Simon Wilson wrote that impartiality "is an admirable idea but manifestly unrelated to the real world ...

\footnotetext{
${ }^{39}$ Bodman, p.85.

40 Bodman, pp.93-6. The "responsible" Federation of Labour opened itself up to media critique following its support for abolishing court injunctions to end industrial disputes, which led to "deeper criticism of trade unionism generally".

${ }^{41}$ Anthony Ward, 'The Facts, Bias and the Post', Salient, 22 March 1976, pp.4-5.
} 
One of the fundamental differences between Salient and the daily press is that they deny this while we do not". 42

Salient's position on objectivity of reporting created tension between the publication and its core readership. On the one hand, Salient was somewhat obligated to report on issues which uniquely pertained to students. Editor Peter Beach summarised Salient's purpose to four primary functions in 1979. The first two of these functions pertained to Salient's role as the student newspaper at VUW:

Salient must provide a service medium for students. It must publicise the activities which involve students or student organisations ... The second responsibility is to ensure that students are kept informed of the activities of their elected representatives. ${ }^{43}$

The agendas and reports from SRC meetings, the manifestos of VUWSA election candidates, reports from NZUSA's May and August Councils, clubs notices, and the VUWSA President's column were all means by which Salient kept students informed of the social and political activities occurring on campus. While SRC meetings or Annual General Meetings generally drew only a small percentage of the student body, many more would have read the reports in Salient. ${ }^{44}$ However, the second and third of Salient's roles as defined by Beach addressed its political coverage:

The third responsibility is more difficult to frame precisely. Our whole university system is based around the precept that it is possible to ignore the events in the outside world. Thankfully VUWSA has not succumbed to this bankrupt policy ... members of the Association debate issues ranging from Library hours to super power contention. Salient too should discuss all these matters ... The fourth responsibility is to provide a forum for debate ... This debate will inevitably involve contentious issues, violently held opinions. ${ }^{45}$

Salient was intentionally political in the 1970s and 1980s, wielding the broad mandate they were granted by its editorial independence from VUWSA to push beyond simply being a campus newspaper. In their first editorial for the year, Franks and Steele wrote that as university and society were inseparable, "Salient this year will be concerned with what is going on outside the university

\footnotetext{
42 Simon Wilson, 'Editorial', Salient, Vol. 41, No. 7, 22 May 1978, p.2.

${ }^{43}$ Peter Beach, 'Editorial: On Manipulating Democracy', Salient, Vol. 42, No. 6, 2 April 1979, p.1.

${ }^{44}$ Mark Cubey, interviewed by Max Nichol, 5 December 2018; Simon Wilson, interviewed by Max Nichol, 8 December 2018.

${ }^{45}$ Peter Beach, 'Editorial: On Manipulating Democracy', Salient, Vol. 42, No. 6, 2 April 1979, p.1.
} 
far more than we will be concerned with what is going on inside it". ${ }^{46}$ Simon Wilson explained that he felt aware that at university, he was surrounded by the lawyers, accountants, public servants, and politicians of tomorrow. Through Salient, he felt he had an opportunity to engage these people politically in the hopes that this might influence the approach they took to their studies and their careers. ${ }^{47}$ Similarly, Cubey's intention was to use Salient to be provocative and initiate conversation and debate amongst the student body. ${ }^{48}$ And in 1985, Hurley wrote that Salient was “here to keep you informed, maybe provoke you a little ... There's so much on campus you can be involved in. And in the wider world too, there's so much going on". 49

Salient's political content was not embraced or agreed with by all students. Though it was the student publication, it is incorrect to assume that Salient was always or even often representative of the general student body regarding social and political viewpoints. As Michael Belgrave notes in his history of Massey University, students were "the vanguard of radical change within a university. But here we need to be careful. Student politics were only partly representative of the whole student body. Massey's student executive and the New Zealand University Students' Association embraced a degree of radicalism ... However, their views were probably not shared, certainly not in their entirety, by the vast majority of students". ${ }^{50}$

Belgrave's caution is worth exercising when considering student politics and student media at VUW. Salient took political positions which were broadly left-leaning and tended to challenge the popular political sentiment of New Zealand. This does not mean it had the full support of the student body. Salient's editors were often accused of presenting a biased, left-wing view of the world, actively denying alternative political views any space. To its critics, Salient appeared to be an exclusive, cliquey group of "trendy leftists" who had no interest in truly representing student opinion. ${ }^{51}$ An anonymous letter to the editor in 1980 levelled that it was "totally ridiculous for Salient to claim to be The Official Student newspaper when it's not the paper of the Students but the mouthpiece of "official" student opinion whether or not the student body supports it or not ...

\footnotetext{
${ }^{46}$ Peter Franks and Roger Steele, 'Editorial', Salient, Vol. 36, No. 1, 28 February 1973.

47 Simon Wilson, interviewed by Max Nichol, 8 December 2018.

${ }^{48}$ Mark Cubey, interviewed by Max Nichol, 5 December 2018.

49 Jane Hurley, 'Editorial', Salient, Vol. 48, No. 4, 25 March 1985, p.2.

${ }^{50}$ Belgrave, From Empire's Servant to Global Citizen: A History of Massey University, p.299.

51 This accusation that Salient was only political and progressive to be "trendy" was relatively common. See for example 'Three Cheers for Constructive Debate', Salient, Vol. 41, No. 13, 6 June 1978, p.15.
} 
Frankly we're bored by it". ${ }^{2}$ Another from 1985 concluded that the "Vic rag now seems to be intent upon inflicting upon us the personal views of those involved with it and nothing else. One last comment. Salient, FUCK UP". 53

Other students simply wanted and expected nothing more from Salient than to be lightly entertained between lectures and kept informed of campus news, outright rejecting Salient's political content. One correspondent in 1974 wrote to Steele to ask: "Who the hell is interested in a workers' march on Parliament? We want the Furry Freak Brothers and not bullshit personal opinions of the irrelevant gabblings of the political minded minority ... It's our newspaper and we don't want screeds of politics". ${ }^{54}$ In 1982 Mark Wilson exercised his editorial discretion by choosing not to publish letters from students writing as satirical characters who collectively formed a bizarre, surreal mythology which had been a feature of the letters page in years prior. One student missed these letters, writing that "most funny letters in past years of Salient have been a good deal less trite than ... Mark Cubey's opinions of Paulette Keating's Opinions of Mark Cubey's opinions". 55

The frustrations of these students stemmed from a feeling of ownership over Salient. Students paid for the majority of Salient's costs through their student association fees. This created accountability to students, which could conflict with the editorial independence that Salient enjoyed, generating tension between Salient and the student body. Membership of VUWSA was mandatory for all students enrolled at VUW, and fee exemptions were only granted if personal financial hardship could be demonstrated. ${ }^{56}$ As such, students who disagreed with the political content of Salient felt that their money was being used to push the political agenda of the editor, rather than reflecting their own interests. For example, an anonymous May 1977 correspondent, writing in response to the editorial decision not to print a letter in a previous issue on the grounds that it was racist, was incensed that a student had been "denied the expression of his or her opinions in his/her newspaper". ${ }^{57}$ In a particularly vitriolic letter from 1978, Simon Wilson was instructed

\footnotetext{
52 800127K, 'You Maggot Infested Piece of Capybara Shit', Salient, Vol. 43, No. 26, 6 October 1980, p.19.

${ }^{53}$ Latka Grawas, 'A Constructive Argument Would Be More Convincing', Salient, Vol. 48, No. 8, 29 April 1985 , p.16.

${ }^{54}$ Frustrated Freaks Assn., "'Who the hell is interested in a workers' march on Parliament"', Salient, Vol. 37, No. 15, 3 July 1974, p.18. The Furry Freak Brothers was a cartoon published in Salient.

55 Stephen Simmonds, 'It's my letters page and I'll cull if I want to', Salient, Vol. 45, No. 19, 9 August 1982, p.15. The title of this letter was written by the editor, as all letter titles were, as a response to its content.

56 John Roseveare, 'A Fees-Ability Study', Salient, Vol. 38, No. 6, 10 April 1975, p.3.

57 'Lost for Words', Salient, 23 May 1977, Vol. 40, No. 11, p.15.
} 
to "go suck yourself in a corner and grow up a bit, perhaps then you will realise your responsibilities towards students ... You seem to forget that Salient is a student newspaper and not Wilsons Weekly" ${ }^{58}$ These kinds of letters demonstrate the feeling amongst students that they were the owners of Salient, and they were frustrated they were not able to control its direction. This gap in what students expected from Salient and what Salient delivered was a consistent source of tension.

Ultimately, Salient was by the VUWSA Constitution permitted to do what it liked with regards to its content, provided it avoided printing anything illegal. The Salient editor was not an elected position, it was not bound to follow the policy created at SRC meetings, and it required distance from VUWSA to be an effective critic of the association's representatives. In the occasional instance that VUWSA attempted to exert too much control over Salient's content, the editor rejected this in strong terms as a violation of Salient's editorial independence. ${ }^{59}$ Beyond the President's column which ran most years, VUWSA had very little control over the content of Salient. The editors had a broad oversight to take the newspaper in whatever direction they wished. Simon Wilson opined that within the insular world of student politics, the editor of Salient did wield quite a lot of power. ${ }^{60}$ When students accused Salient of bias or lacking objectivity, the response from the editor was often that, unlike the mainstream press, Salient never had to be or intended to be objective in the first place. In response to an accusation of bias in 1973, Franks and Steele wrote that contrary to what their critic had asserted, they had "never claimed that Salient is “an impartial, liberal paper"”. ${ }^{61}$ Discussing accusations of bias in 1983, Cubey wrote that while everyone was political, "some people just pretend they're not", asserting his right to exercise his editorial authority to include in Salient whatever content he saw fit. ${ }^{62}$

This is not to say Salient was totally unaccountable. Salient did have to prepare a detailed budget and report to the Publications Board and the VUWSA Executive to justify and explain its production costs. ${ }^{63}$ As such, there was some need to exercise and demonstrate responsibility when spending students' money in order to receive funding from VUWSA. The VUWSA executive also had the power to initiate a vote of no confidence in the Salient editor, which if successful would

\footnotetext{
58 S.D. Separd, '3 Cheers for constructive debate', Salient, Vol. 41, No. 13, 6 June 1978, p.15.

${ }^{59}$ See for example Peter Beach, 'Editorial: On Manipulating Democracy', Salient, Vol. 42, No. 6, 2 April 1979 , p.1.

60 Simon Wilson, interviewed by Max Nichol, 8 December 2018.

${ }^{61}$ Peter Franks and Roger Steele, 'Give us a fair go, mate', Salient, Vol. 36, No. 20, 29 August 1973, p.19.

62 Mark Cubey, 'editor', Salient, Vol. 46, No. 4, 21 March 1983, p.2.

${ }^{63}$ Mark Cubey, interviewed by Max Nichol, 5 December 2018.
} 
dismiss them from the position. This was used in 1980, unsuccessfully, in an attempt to oust Stephen A'Court. ${ }^{64}$ The Executive could also move to censure the editor, a less serious action than a vote of no confidence while still sending a strong rebuke. For example, the Publications Board censured Adams for firing his technical editor Grant O’Neill in 1986. While he was technically within his rights to do so, VUWSA and the Publications Board felt the dismissal had been unjustified, hasty, and in bad faith. Business Manager and Sports Officer Andrew Little threatened to resign in protest over Adams' actions. After deliberations, the Publications Board ruled that O'Neill be reinstated, that Adams publish a written apology in Salient, and that Adams be officially censured by the Board. ${ }^{65}$ Although this was something of a hollow threat - Adams sought legal advice and found that VUWSA probably had no grounds on which to actually dismiss him - he abided by these terms nevertheless.

Most importantly though, Salient's editors did express a commitment to allowing Salient to be a forum which was accessible to any and all students who could string a sentence together. They had broad discretion to reject or accept articles, and they did exercise that discretion. Responding to Mike Treen's accusation that Simon Wilson was denying Treen's submissions to Salient as a matter of editorial policy, Wilson responded that it was "true I have on occasion declined your offers of articles for Salient. That is my prerogative with any potential contributor". 66 But a common response to criticisms that Salient was politically biased was that the critic should simply submit an article presenting their view. If it was coherent and based in fact, the editor would run it. Reporting on a forum on the state of Salient in 1973, David Tripe wrote that "one bunch of idiots thought that there weren't enough right-wing articles for their taste but refused to do anything about it". ${ }^{67}$ Hurley wrote that Salient was not presuming to speak for students, Salient was a "voice to students ... You think that if what you write doesn't correspond to my own narrow band of beliefs and observances, then you might not get published? Why don't you write whatever you want to, submit it and then see what happens". ${ }^{68}$

\footnotetext{
64 Paulette Keating, 'Editor retains position', Salient, Vol. 43, No. 26, 6 October 1980, p.6.

65 'Salient Editor Told Resign or Else...', Salient, Vol. 49, No. 22, 22 September 1986, p.3.

${ }^{66}$ Simon Wilson, 'Treen complains', Salient, Vol. 41, No. 9, 24 April 1978, p.19.

${ }^{67}$ David Tripe, 'Forum on Salient', Salient, Vol. 36, No. 15, 5 July 1973, p.2. In a show of presenting differing political opinions, Salient did run a regular right-wing column in 1974, named Right Hand, per Roger Steele, interviewed by Max Nichol, 16 December 2018.

68 Jane Hurley, 'Editorial', Vol. 48, No. 4, 25 March 1985, p.4.
} 
The letters pages were where this commitment to publishing a spectrum of political opinion was best realised. It was a forum where students could have their say about the content of Salient, whether that was an informed (or foul-mouthed) rebuke of an article, a tirade at the editor, or a gripe with some aspect of being at university. It was in the letters to the editor that most right-wing or conservative opinions were voiced in Salient. Steele maintained the policy of publishing all letters he received provided they weren't libellous, as an expression of his commitment to promoting Salient as a forum anyone could access. ${ }^{69} 1980$ s letters policy came with the proviso that Salient would not print a letter which was "sexist, racist or in extreme bad taste", but remained a space for opinions of all stripes within Salient, even those the editor disagreed with. ${ }^{70}$ Certainly, the vast majority of substantive articles in Salient were left-leaning, but Salient's commitment to publishing dissenting opinions was honoured to some degree, albeit primarily within the letters to the editor.

It is important to note that in the 1970s, it was not only conservative opinions which tended not to be represented in substantive articles in Salient. Throughout the 1970s, there existed a major ideological split between socialist groups, particularly Maoists and Trotskyists. Salient and VUWSA broadly fell on the Maoist side of this divide through its close association with the Wellington Marxist-Leninst Association (MILO), while campus group the Young Socialists, a branch of off-campus organisation the Socialist Action League, took a Trotskyist analysis. The implications this socialist presence had for what was included in Salient will be explored in depth in Chapter Two. This animosity also affected who did not have access to Salient, demonstrating how the politics of individual editors could compromise commitments to Salient being a publication all students could in theory gain access to.

The Young Socialists took issue with the fact that the Maoists controlled (to a degree) the instruments of student politics, the executive and the newspaper, and accused Salient editors of censoring their analysis whenever it was submitted for publication. Steele and Franks openly voiced their anti-Trotskyist stance in an editorial responding to accusations of censorship of the Young Socialists. They reckoned that in fact "an excellent case could be made out that we are a pro-Trotskyite paper ... If, as the pundits say, all publicity is good publicity, then it's time we sent

\footnotetext{
${ }^{69}$ Roger Steele, interviewed by Max Nichol, 16 December 2018.

70 'Letters', Salient, Vol. 1982, Vol. 45, No. 3, 15 March 1982, p.15.
} 
the Trots a bill for all the rubbishing we've given them". ${ }^{71}$ Particularly inflammatory was the decision to hang an ice-pick, the item used to assassinate Leon Trotsky, in the window of the Salient office. $^{72}$ Bruce Robinson expressed the same distaste for Trotskyist analysis in 1975, writing that "Not only do the Trotskyites through Socialist Action treat their readers and supporters as having the level of intelligence of children but they also treat their political opponents as having the same level of intelligence". ${ }^{73}$ For this he was accused of displaying the "narrow-mindedness peculiar to followers of Mao in refusing to print articles that presented the views of your political opponents on the left". ${ }^{74}$ David Murray edited Salient in 1977 and Simon Wilson in 1978. Both were MILO members who openly feuded with the Young Socialists in Salient over ideological differences and the group's access to the paper. Murray was deeply committed to the idea that the Trotskyists, not right-wingers, were the true enemies of MILO, while Wilson admitted that it was "very rare that a Trotskyist had any copy accepted". ${ }^{75}$ In 1977, the Young Socialists went as far as printing their own Salient competitor titled Censored Salient which levelled that Salient's “journalistic approach has been ... mindless anti "Trot" comments" and that the Young Socialists were being actively denied the right of reply beyond publication on the letters page. ${ }^{76}$

Leaving aside the effect of feuding socialist factions upon Salient's access policy, it was perhaps inevitable that Salient was unable to represent all strands of student opinion. Trying to presume to speak on behalf of an amorphous, politically diverse, and ever-expanding student body was a constant dilemma for Salient's editors and contributors. In 1982, Michele A'Court, addressed the difficulty of catering to the views of 6000 students. She noted that the "most frequent criticism of "Salient" since I have been involved with it is its level of politics. Many a letter has been written and a few SGMs have been called to discuss this subject ... on the one hand, people think the paper is too political, on the other people say it is not political enough". ${ }^{77}$

\footnotetext{
${ }^{71}$ Roger Steele and Peter Franks, 'Editorial: Why We're not Too Fond Of The Trotskyites', Salient, Vol. 36, No. 12, 6 June 1973, p.3.

72 Peter Franks, interviewed by Max Nichol, 20 December 2018.

73 Bruce Robinson, 'Intercontinential arrogance', Salient, Vol. 38, No. 17, 16 July 1975, p.4.

74 Tony Lane, 'Lane Replies', Salient, Vol. 38, No. 18, 23 July 1975, p.15.

75 Margie Thomson, interviewed by Max Nichol, 9 December 2018; Simon Wilson, interviewed by Max Nichol, 8 December 2018.

76 Juanita Doorey, 'Censored Salient', Censored Salient, No. 1, 23 May 1977, p.1. Censored Salient also featured an article accusing the Chinese government of falsifying history in what was a direct attempt to discredit the basis of Maoist socialism.

77 Michele A'Court, 'Guest Editorial', Salient, Vol. 45, No. 13, 14 June 1982, p.2.
} 


\section{Salient's position within print media}

As was the case globally, print in New Zealand was an important part of activism in New Zealand in the 1970s and 1980s. As Steele put it poetically, referencing the light table used to design the layout of print publications: "Light draws moths and it draws radicals". ${ }^{78}$ Toby Boraman has written about the role of print in the organisation and education of radicals, communists, and other leftists in New Zealand in the twentieth century. He argues that in the 1960s, New Zealand did not sustain a radical print culture as theoretically robust as that of Britain or the United States. Publications were short-lived and tended to focus on organisation of activism, which while important lacked the analytical rigour of publications overseas. ${ }^{79}$ This largely remained the case throughout the 1970s, 1980s, and 1990s, though some publications did begin to address the development of theory as it related to activists in New Zealand. While Boraman contends that publications such as Race Gender Class, Bruce Jesson's The Republican, and Red Papers did not achieve the "richness, variety, robust debates and innovations of theoretical journals overseas", they nevertheless did work to push forward theory as it pertained to activism in New Zealand. The Republican and especially Race Gender Class developed a class analysis of New Zealand society which appreciated the discrete but compounding effects of gender and race. ${ }^{80}$ Donna Awatere's 1982-83 articles in Broadsheet, published as a collection titled Maori Sovereignty in 1984, challenged Pākehā activists to support Māori activists' calls for rangatiratanga, a powerful challenge which "hit the left like a shockwave". ${ }^{81}$

In establishing itself in opposition to the mainstream media, Salient can be seen as what Chris Atton defines as an "alternative" publication. His definition of alternative is intended to be a "blanket term" for publications which report on stories which tend not to be covered by the mainstream press, and in ways which are not typical of the mainstream press. ${ }^{82}$ This was the case for Salient. For example, in 1969, a teach-in that discussed Security Intelligence Service activity on campus was "reported in the student and radical press, [while] other media ignored it completely". 83

\footnotetext{
78 Roger Steele, interviewed by Max Nichol, 16 December 2018.

79 Boraman, "The New Left in New Zealand," p.121.

${ }^{80}$ Boraman, "The Independent Left Press and the Rise and Fall of Mass Dissent in Aotearoa since the 1970 s," p.34.

${ }^{81}$ Boraman, p.53.

${ }^{82}$ Atton, Alternative Media, pp.9-10.

${ }^{83}$ Hamilton, A Radical Tradition, p.134.
} 
Megan Simpson's thesis on the Resistance Bookshops in Wellington, Auckland, and Christchurch also explores the significance and content of radical and alternative print cultures in New Zealand. The Resistance Bookshops operated independently between 1969 and 1977. Simpson is less equivocal than Boraman about the importance of print for activism in New Zealand, writing that "from the late 1960s print became a key part of radical politics in New Zealand". ${ }^{84}$ The Resistance Bookshop was a site for circulation of radical and alternative print material, which ranged from books and local publications to more ephemeral print material such as leaflets or brochures. The Resistance Bookshop in Wellington, which operated between 1970 and 1976, had its own printing press, and had a hand in producing much of these kinds of local materials. Simpson notes that these publications had "small circulation runs or a limited readership" but nevertheless played an "important role as it got radical ideas and political views out into the public sphere". ${ }^{85}$ Here, there is a key distinction between Salient and other leftist publications - the consistency of publication and reliability of funding. Simpson notes this discrepancy briefly, writing that 'Victoria University's Salient, while not 'underground', as it was funded by an institution, faced some of the same problems as other underground publishers". 86 Funding from VUWSA fees allowed Salient a degree of certainty other publications did not enjoy. Funding could change from year to year, but it was always forthcoming. Accordingly, there was always a new copy of Salient in stands each Monday during the academic year.

Nevertheless, Salient did have to contend with some of the same issues as other alternative publications. New Zealand had relatively strict censorship and libel laws in the 1970s and 1980s, which placed restrictions on what could be published. These laws were primarily deployed to censor or otherwise impede the alternative or radical press in New Zealand. Simpson notes that the publications Itch and Ferret, produced at the Wellington and Christchurch Resistance Bookshops respectively, were both subject to police attention due to the provocative nature of their content. ${ }^{87}$ The content of Salient was the subject of these restrictive laws with some regularity. Indeed, in a twist of irony, an article from 1973 which addressed "harassment of all the Resistance centres", a police raid on the Ferret offices in Christchurch, and a charge laid against Ferret contributor Marty Braithwaite, two lines had been pasted over and labelled "deleted on legal

\footnotetext{
${ }^{84}$ Simpson, "Radical Spaces," p.97.

${ }^{85}$ Simpson, p.98.

${ }^{86}$ Simpson, p.107.

${ }^{87}$ Simpson, p.108.
} 
advice". The reason for this deletion was explained in the very same article: "This is also one of the few countries in the world where the printer, as well as the publisher, is liable for the material they print. This in fact leads to the situation where printers leave their role as straight printers and become censors as well". 88

As Salient's printer, Wanganui Newspapers removed copy which they deemed libellous or likely to violate the Indecent Publications Act with some regularity. Likewise, Salient did face costly legal repercussions for some material they printed. The events of 1982 serve as a good example of both. Almost the entirety of the cover of the second issue for 1982 was removed by the printer, as was most of the fourth page, leaving gaping holes in the issue, replaced with the words "This article has been removed by the printer" (Figure 1). ${ }^{89}$ The response from Salient was tongue-in-cheek. A satirical piece made light of New Zealand's publication laws, imagining that the bold editorial decision to publish a blank cover was being lauded by Salient's supporters for its commitment to fearless journalism, and lambasted by the likes of Robert Muldoon and "Miss Pat Barlamb", a play on the name of conservative lobbyist Patricia Bartlett. Salient joked that Barlamb had sent the offending cover to the Indecent Publications Tribunal and was "quoted" as saying that this would "definitely [be] the test case. If they let this one through, they'll let through anything".90

The eventual resolution of the blank cover affair was rather more serious. The article which had been removed addressed the incompetent administration of the Student Community Service Programme, a collaborative programme between VUW and the Department of Labour which helped students find paid work over the summer break. The article was the work of an investigation by Salient reporter Michele A'Court, who interviewed a number of students about their experiences with the SCSP. The story involved criticisms of a specific VUW staff member, Henk Huber. Many of the students A'Court spoke to held Huber principally responsible for the issues with the programme, which included underpayment, poor work conditions, and poor treatment by employers. It was originally removed by the printers because VUWSA's usual lawyer was out of Wellington when A'Court filed her copy. While another lawyer had checked the story and assured the printers that it was legally defensible if Huber brought a charge of libel against the printers,

\footnotetext{
88 'Ferret: The Regime Strikes', Salient, Vol. 36, No. 20, 29 August 1973, p.3.

89 'This article has been removed by the printer', Salient, Vol. 45, No. 2, 8 March 1982, pp.1, 4.

90 D.R. Winter, 'Steamy Salient cover causes sensation', Salient, Vol. 45, No. 4, 22 March 1982, p.4.
} 


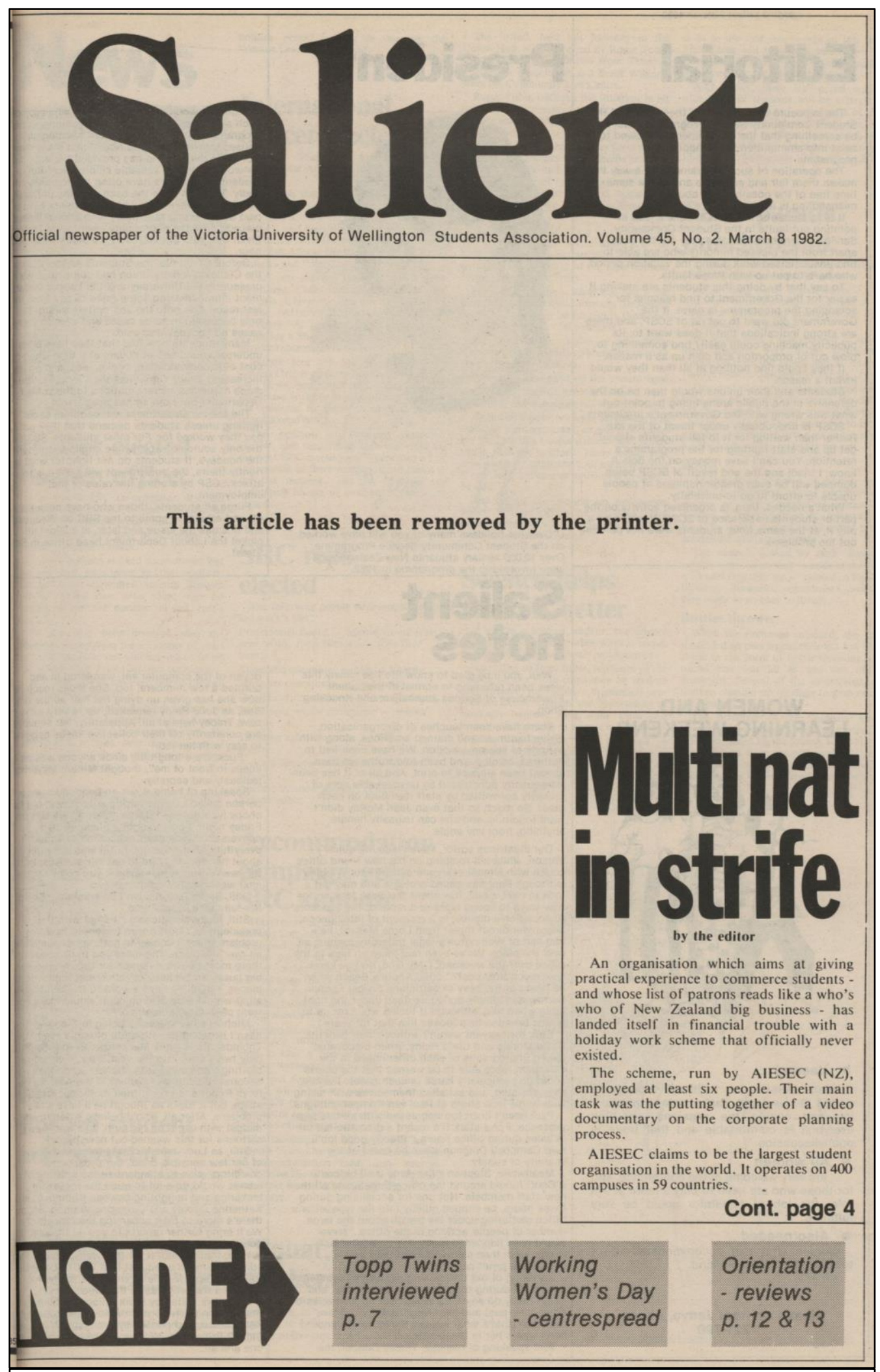

Figure 1 'This article has been removed by the printer', Salient, Vol. 45, No. 2, 8 March 1982, p.1. 
Wanganui Newspapers was uncomfortable running the story without the assurance of the Association's regular lawyer. The story ran on the front page of the third issue, following some minor amendments by VUWSA's lawyer upon his return to Wellington. ${ }^{91}$ A follow-up article was published in the fourth issue, which again named Huber as primarily responsible for the issues with the SCSP. ${ }^{92}$

Huber was not pleased. Several weeks after the articles had gone to print, his lawyer served VUWSA and Wanganui Newspapers with a writ holding them responsible for Salient's allegedly libellous content against Huber. Though VUWSA's lawyer remained confident the articles were legally defensible, VUWSA settled before the case went to court, believing that the case would be costly, hard to win, and stacked against them due to the dubious reputation of student media. As part of the settlement, Salient published an apology on the front page of issue fourteen in 1982. VUWSA also paid \$1600 for Huber's legal fees, \$500 for Wanganui Newspapers' legal fees, and $\$ 500$ for their own. ${ }^{93}$ The affair caused a rift between Mark Wilson and the VUWSA Executive. The Executive proposed a motion that Wilson be required to publish a full account of the legal challenge, to explain to students how and why Salient had lost \$2600 of their money. As he had already intended to do this, Wilson interpreted the motion as a vote of no confidence in his editorship. He resigned in protest on Friday 30 July, only to withdraw his resignation on the afternoon of Sunday 1 August after deciding this would have had too adverse an effect on the production of Salient for the rest of the year. ${ }^{94}$ The Huber affair was not the only occasion when Salient's printers removed copy to protect their own legal interests, nor was it the only time Salient had legal challenges brought against it. It demonstrates the restrictive atmosphere New Zealand's laws generated for the media, particularly the alternative and radical press, in the 1970s and 1980s, which Salient had to contend with.

Though Salient had the capacity to print material which resulted in legal action, it was not quite so controversial as other alternative publications such as Wellington's Cock, published from 1967-1976. Cock editor Chris Wheeler established his own printing press, Cockerel Press, because he was unable to find a printer in Wellington willing to print his material. This allowed Cock to circumvent the printer-side censorship Salient faced from Wanganui Newspapers and publish more

\footnotetext{
91 Michele A'Court, 'Exclusive: Job Scheme Badly Run', Salient, Vol. 45, No. 3, 15 March 1982, p.1.

92 Michele A'Court, 'Mopping Up SCSP', Salient, Vol. 45, No. 4, 22 March 1982, p.5.

93 'Huber settlement - background', Salient, Vol. 45, No. 18, 2 August 1982, p.4.

${ }^{94}$ Mark Wilson, 'A personal statement from the editor', Salient, Vol. 45, No. 18, 2 August 1982, p.1.
} 
controversial material. ${ }^{95}$ There was some informal relationship between Salient and the radical press in Wellington. 1972 Salient co-editor Roger Cruickshank helped to establish Resistance Press, an independent printing press at the Wellington Resistance Bookshop, in $1973 .{ }^{96}$ Steele and Franks had a relationship with Wheeler. Steele explained that some stories which were deemed too radical for Salient might be handed off to Cock for publication. Similarly, both Franks and Steele mentioned instances when they had an insert printed at Cockerel Press because they were concerned articles would not make it past the printers. ${ }^{97}$ Steele provided the example of an article defending Bill Sutch after Sutch became the first New Zealander to be charged under the Official Secrets Act $1951 .^{98}$ These were then painstakingly inlaid into the copies of Salient which arrived from Wanganui Newspapers. In sum, while Salient occupied a space within Wellington alternative print culture, it faced greater restrictions on content that pushed legal boundaries due to printerside censorship and the cost to VUWSA when its content had legal consequences. This was an important distinction between Salient and other alternative publications.

Another key difference was that Salient had a relatively captive readership in students. Much of the evidence of readership numbers and number of copies picked up is impressionistic due to the difficulty in locating this information. ${ }^{99}$ Based on impressions gleaned from both contemporary reflections of the editors and from oral history interviews conducted for this thesis, Salient was widely read by students in the 1970s and 1980s. ${ }^{100}$ Steele, Simon Wilson, and Cubey all recalled that most of the copies distributed around campus were picked up by students. There was also some circulation of Salient off campus. In 1965, co-editors Hugh Rennie and John Llewellyn attempted to directly compete with Sunday papers, changing the design and size of the paper to conform to that of a Sunday paper and selling it at "corner shops throughout Wellington". ${ }^{101}$ In 1983, both Unity Books and Capital Books stocked Salient. ${ }^{102}$ Steele recalled that during his time at Salient, copies made their way to Parliament each week, where some MPs

\footnotetext{
${ }^{95}$ Simpson, “Radical Spaces," p.108.

96 Simpson, p.73.

97 Roger Steele, interviewed by Max Nichol, 16 December 2018; Peter Franks, interviewed by Max Nichol, 20 December 2018.

${ }^{98}$ Roger Steele, interviewed by Max Nichol, 16 December 2018.

${ }^{99}$ Though in 1987 Salient was having 6000 copies of the newspaper printed each week for a full-time student population of around 8000, giving some indication of expected reader numbers. See Grant O'Neill, 'editorial', Salient, Vol. 50, No. 2, 9 March 1987, p.1.

100 Though, different students likely read Salient in varying degrees of depth.

101 Hamilton, A Radical Tradition, p.133.

102 'Salient is available downtown', Salient, Vol. 46, No. 14, 4 July 1983, p.3.
} 
checked to see if they had been the subject of any reporting. ${ }^{103}$ Max Rashbrooke, Salient editor in 2002, has even described Salient as "the capital's longest-running magazine". ${ }^{104}$ While this is something of a misnomer - Salient in the 1970s and 1980s was almost always referred to as a newspaper or a paper, and only began to be published in a magazine format around the late 1990s - Rashbrooke's characterisation nevertheless recognises both the longevity of Salient, and the fact that Salient had at least some cut-through with Wellington's non-student population. Salient ranks among the most consistently published and potentially most widely read leftist publications in Wellington in the 1970s and 1980s.

The focus of this project is on Salient, not student media in New Zealand generally, but it is possible to comment on some of the interactions between student publications. Salient's editors were aware of what other student publications were reporting on, and a loose confederation of student publications existed. Issues of other student newspapers were available at the Salient offices for Victoria students to read. As well as fulfilling their statutory requirement to deposit a stack of issues of Salient to the National Library each week, editors sent a stack of copies to the editors of other campus newspapers and vice versa. ${ }^{105}$ In 1986, Salient made students aware that if they were interested in news from other campuses, they had copies of all the student newspapers from New Zealand universities "as well as occasional Aussie papers" available to borrow or browse at the Salient office. ${ }^{106}$ It was not uncommon for the letters page to carry correspondence from students at other universities responding to Salient's content. While it was likely only readers with a keen interest in student media and student politics would have gone out of their way to read other student newspapers, they were available for those interested.

There were also instances of more direct collaboration between student publications. Hurley recalled that the editors of different publications were loosely in touch with one another and there was an understanding of collaboration and solidarity amongst them. The most concrete examples of this collaboration were National Student Issues. These were ambitious attempts to put out a student publication which featured content from every university newspaper, to be circulated on every campus. They were few and far between. Three National Issues were published in 1978, each with a different theme. The next National Issue was a one-off published in 1986, directly

\footnotetext{
103 Roger Steele, interviewed by Max Nichol, 16 December 2018.

104 Max Rashebrooke, “Mag Men (and Women)," FishHead, July 2012, p.40.

105 Mark Cubey, interviewed by Max Nichol, 5 December 2018.

106 'Interested in news from other campuses?', Salient, Vol. 49, No. 7, 28 April 1986, p.3.
} 

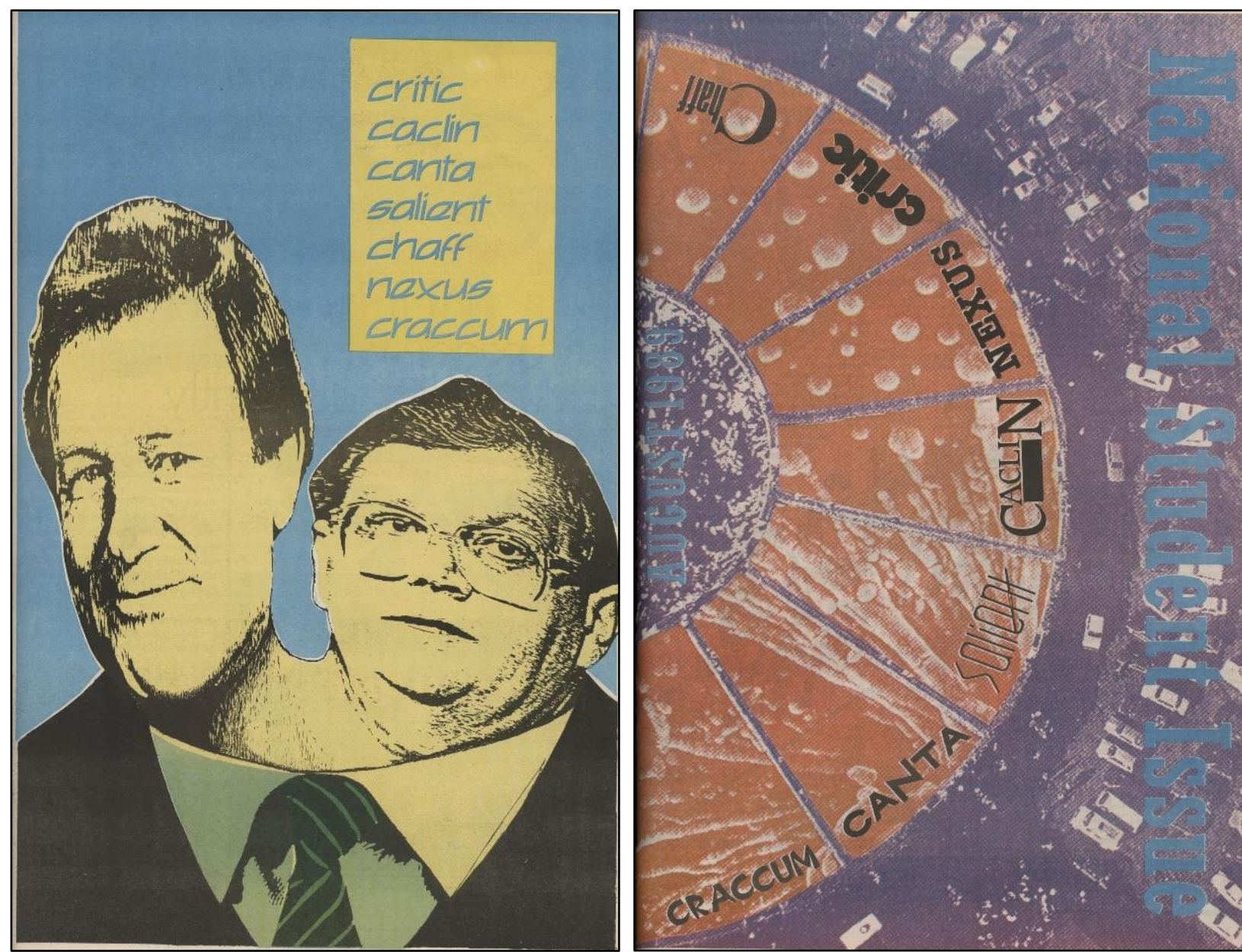

Figure 2 The covers of the National Student Issues produced in 1987 and 1989. Left: Salient, Vol. 50, No, 18, 1987, p.1. Right: Salient, Vol. 52, No. 18, 1989, p.1.

inspired by the National Issue of $1978 .{ }^{107}$ Carrying on this tradition, National Issues were also published in 1987 and 1989 (Figure 2). ${ }^{108}$ For a short time in the late 1980s, student publications also got their ads through the same ill-fated enterprise named Student Media Marketing, founded in 1986. It sold ads on behalf of a number of student newspapers and radio stations, including Salient and VUWSA's student radio station, Radio Active. Salient withdrew from this relationship in 1988, due to Student Media Marketing's failure to provide an adequate amount of advertising, the substantial debt the enterprise had taken on, and the pressure to run "aditorial" content, sponsored articles presented as ostensibly regular content. ${ }^{109}$

\footnotetext{
107 Richard Adams, 'Editorial', Salient, Vol. 49, No. 17, 1986.

108 See Salient, Vol. 50, No, 18, 1987 and Salient, Vol. 52, No. 18, 1989.

${ }^{109}$ Dean Bedford, 'Buy, Sell \& Estrange', Salient, Vol. 51, No. 16, 18 July 1988, pp.6-7; 'Studass leaves Student Advertising Company', Salient, Vol. 51, No. 18, p.3.
} 
These examples demonstrate that student media in New Zealand was coordinated to some degree. This does not necessarily mean that all student publications shared the same characteristics as Salient - such a conclusion is not possible without a similar analysis of other student publications as that conducted here. Indeed, Steele and Franks noted in 1973 that unlike their vision for Salient, the editor of Critic had made an editorial decision to observe objectivity in its reporting, and to focus on campus news. ${ }^{110}$ As the student publication based in Wellington, it is also possible that Salient had a particularly political line given its proximity to Government and the public sector, allowing for greater access to the beating heart of New Zeland politics. Nevertheless, it is worth noting that as well as sitting alongside alternative publications, Salient maintained relationships with other student publications which were published in similar circumstances.

\section{Conclusion}

As a publication, Salient transcended its role as the campus newspaper at VUW. The gritty offices in the Student Union building became a haven for young, politically engaged students who wanted to contribute to Salient's creation. Leveraging the financial security afforded by VUWSA funding and a mandate for editorial independence, Salient's editors rejected the conventions of the mainstream media and embraced the opportunity to use Salient as a political platform. This caused some tension with its core readership. Not all students shared the opinions expressed in Salient, and some felt that it had no business being political at all. However, Salient committed in principle to at least publishing as wide a variety of student opinions as possible. The letters page performed this function the best. However, ultimately editors had the right to include or exclude content as they saw fit, and they exercised this right frequently. The editor of Salient was able to deploy the newspaper to take direct political stances. Taken as a whole, these characteristics place Salient within the alternative print culture that existed in the 1970s and 1980s. The following chapters examine in more detail the kind of alternative publication Salient was, looking at the specific political views and currents Salient expressed and reported on, and how this changed over time as its editors and the political circumstances they operated in changed.

110 Peter Franks and Roger Steele, 'Editorial', Salient, Vol. 36, No. 4, 2 March 1973, p.3. 


\section{Chapter Two}

\section{Salient Through the Long 1970s: Activism and Socialism, 1968-1981}

The years described as the "Long 1970s", which span from the late 1960s to the early 1980s, were characterised by a groundswell of student radicalism around the world. New Zealand was no exception. Communism, socialism, feminism, and Māori land rights informed the causes that proliferated on Victoria University campus. In the 1950s and early 1960s, Salient was a newspaper concerned primarily with campus news. However, by 1973, Salient represented the growing stable of political causes to which student activists dedicated their energy. In particular, socialist ideology informed many of the issues Salient reported and commented on. Most of the 1970s editors of Salient, and many of the contributors (as well as a number of the students' association Executive members), were members of the Wellington Marxist-Leninist Organisation (MILO) or the groups which it formed out of. MILO was a small Maoist-aligned group officially formed in 1976 but preceded by and associated with Maoist activity in Wellington since the early 1970s. The group had a substantial student membership. Salient was not entirely dominated by the agenda of MILO - it still had a responsibility to all students and student issues - and not all contributors were members. Roger Steele, who was close to but not aligned with the Maoists, was an early champion of te reo Māori on campus, bringing a unique level of support for Māori issues to his editorship in the publication of Te Ao Marama. Nevertheless, much of Salient's content applied MILO's class-based, anti-capitalist analysis of society to its reporting. In the early and mid-1970s, Salient frequently commented on the nature of the university itself, casting it as elitist, a tool of the capitalist ruling class, and imagined how tertiary education could better serve all New Zealanders. These expansive critiques of the university were curtailed when Robert Muldoon's National government was elected and student activists faced funding cuts to students and universities. Opposition to these cuts, however, continued to be expressed as a class issue in Salient; they prevented working-class people from accessing university education. Solidarity with working-class trade unions, also attacked by the National government, was encouraged. Salient in the 1970s was in many ways an extension of the activism and political views of its editors and contributors. They practiced a style of journalism which was closely integrated with protest and applied a relatively consistent socialist ideology. The highpoint of this style of journalism was 
during the 1981 Springbok Tour, where Salient reporters were conduits for organising anti-tour activity as well as keeping readers abreast of events occurring around the country.

Salient was founded with radical intent, but by the 1950s and early 1960s, it was a relatively conservative publication. It focused primarily on campus news with little in the way of political content. ${ }^{1}$ However, as 1960 s students began to reject the conservatism of their parents' generation, so too did Salient begin to revitalise its radical past. From the mid-1960s, the paper had a series of editors who tackled political and often controversial topics such as the 1964 murder of Christchurch gay man Charles Aberhardt, the Vietnam War and the government's use of SIS agents to spy on students at Victoria University of Wellington (VUW). ${ }^{2}$ Salient became a weekly publication for the first time in 1968, covering more issues in greater depth and regularity. ${ }^{3}$ The introduction of Student Representative Council meetings into the constitutional fabric of Victoria University of Wellington Students' Association (VUWSA) allowed for the Association to debate and adopt policies which were more openly political. These meetings were relatively well-attended and lively in the early 1970s: "There'd be a Hyde Park situation in the top floor of the Student Union ... you never knew what was gonna happen next".

These developments within Salient and VUWSA reflected the broad student protest culture which emerged in the late 1960s. In 1968, students and workers engaged in disruptive protest activity which challenged the economic and social status quo across the world and in New Zealand, launching a period of protracted political activity across a variety of issues. ${ }^{5}$ New Zealand's trade unions, galvanised by the Nil Wage Order, ramped up levels of industrial action. ${ }^{6}$ Though opposition to New Zealand's involvement in the Vietnam War had existed prior to 1968, it became a massive focus for protesters' energy. Small, relatively mild protest events organised by university-based groups such as the Committee on the Vietnam War, communists and pacifists, became large-scale protests against the Vietnam War by 1970; Trotskyist group the Socialist Action League played a key role in galvanising Victoria University students to swell protest

\footnotetext{
${ }^{1}$ Barrowman, Victoria University of Wellington 1899-1999: A History, p.319.

${ }^{2}$ Hamilton, A Radical Tradition, pp.132-6.

${ }^{3}$ Hamilton, p.135.

${ }^{4}$ Roger Steele, interviewed by Max Nichol, 16 December 2018.

${ }^{5}$ Bracke, "The 'Spirit of 1968': Cultural Revolution," p.157; Boraman, "Revisiting the Global and Local Upheavals of $1968, "$ p.40.

${ }^{6}$ Bodman, "'The Public Have Had a Gutsful and So Have We': The Alienation of Organized Labour in New Zealand, 1968-1975," p.84.
} 
demonstrations. ${ }^{7}$ Sporting contact with South Africa in 1970 and 1973 generated major opposition to New Zealand's apparent condonement of the violently oppressive and baldly racist apartheid regime; Halt All Racist Tours, formed in 1969, drew students to its cause. From around 1970, the term "Women's Liberation" gained currency, representing a new wave of feminist thought and action which tackled the inequality faced by women and advocated for greater bodily autonomy for women. At VUW, the Wellington Women's Liberation Front was founded to address these issues. ${ }^{8}$ Groups such as Ngā Tamatoa, founded at the University of Auckland, made powerful critiques of the settler state, declaring the Treaty of Waitangi to be a fraud and calling for the revitalisation of te reo Māori and recognition of Māori land rights. ${ }^{9}$ It is these issues this chapter focuses on. Salient also reported on action on environmental protection, peace and disarmament, and gay liberation, as well as a number of other areas of protest action which for reasons of space are beyond the scope of consideration here. Though students were far from the only group involved in the protest and alternative cultures of the late 1960s and early 1970s, they did form a significant block. University campuses became sites of organisation and forums for discussion of the political and social issues facing New Zealand and the world, and at Victoria University, Salient was the publication reporting them.

Salient's editors for 1973, Peter Franks and Roger Steele, had both come through the protest movements of the late 1960s and early 1970s, particularly the anti-Vietnam War and antiapartheid movements. Describing himself as a "known rebel" from his mid-teens, Steele was involved in protests against the Vietnam War and New Zealand's sporting contact with apartheid South Africa. These experiences "roped me in, and I was ruined for life". Steele gained an appreciation for the power of print, writing for an unofficial school magazine, Pleb, at his high school in Rotorua, and then for Critic as an Otago University student in the late $1960 \mathrm{~s} .{ }^{10}$ Franks had had similar experiences, having been active in anti-Vietnam War protest activity in Wellington in the 1960s and early 1970s. Both Steele and Franks became regular contributors to Salient in

\footnotetext{
${ }^{7}$ Belich, Paradise Reforged, p.515. Belich notes that of the 339 street demonstrations between 1967 and 1970, "most were about this issue".

${ }^{8}$ Dann, Up From Under, p.5.

${ }^{9}$ Aroha Harris and Melissa Matutina Williams, "Rights and Revitalisation, 1970-1990," in Tangata Whenua: $A$ History, ed. Atholl Anderson, Judith Binnney, and Aroha Harris (Wellington: Bridget Williams Books, 2015), pp.35860.

${ }^{10}$ Roger Steele, interviewed by Max Nichol, 16 December 2018.
} 
1972. ${ }^{11}$ Franks and Steele did not know each other particularly well when they entered into their co-editorship, but it proved a fruitful partnership. Franks was an articulate writer and a touchtypist, while Steele had an aptitude for editing and design. They shared a common belief that Salient under their editorship should concern itself primarily with the political activity occurring outside the university. ${ }^{12}$ Steele carried this ethos forward as the sole editor in 1974.

Concurrent with the expansion of protest activity, socialist and communist ideas found proponents amongst university students in the late 1960s and early 1970s. Ron Smith notes there was an uptick in communist ideas on New Zealand's university campuses, "particularly in Wellington," after 1968. ${ }^{13}$ At VUW there were a number of socialist groups and factions on campus. The Socialist Club was founded in 1969 and produced a short-lived publication called Red Spark. Some of its members had a hand in forming the Socialist Action League, a Trotskyist political party, which had a presence on campus in the Young Socialists. ${ }^{14}$ The October Club was founded in 1974 to promote socialism on campus. ${ }^{15}$ But the organisation with the most relevance to Salient was the Wellington Marxist-Leninist Organisation, shortened to MILO. With a sizeable student membership, Smith described MILO as being "stamped with ... student intellectual origins". ${ }^{16}$ The organisation was formed in 1976, emerging out of anti-tour groups Halt All Racist Tours (HART), the Committee on Vietnam, and former members of the Communist Party of New Zealand (CPNZ), including Smith, Mike Scott, and Rona Bailey. ${ }^{17}$ It also had its genesis in the Paper Collective. This was a broader leftist group which produced The Paper, a publication which was sold to workers at factories in the Hutt Valley, and proved very popular. ${ }^{18}$ Though not all members of the Paper Collective joined MILO, there was substantial crossover. ${ }^{19}$ MILO was an exclusive organisation; membership was by invite only, and members operated in cells, meeting regularly only with those they needed to. ${ }^{20}$

\footnotetext{
${ }^{11}$ Peter Franks, interviewed by Max Nichol, 20 December 2018.

12 Peter Franks, interviewed by Max Nichol, 20 December 2018.

${ }^{13}$ Smith, Working Class Son, p.162.

${ }^{14}$ Boraman, "The Independent Left Press and the Rise and Fall of Mass Dissent in Aotearoa since the 1970s," pp.45-6.

${ }^{15}$ Hamilton, A Radical Tradition, p.163.

${ }^{16}$ Smith, p.163.

${ }^{17}$ Ibid., pp.162-3; Robert Reid, interviewed by Cybèle Locke, 27 January 2015.

${ }^{18}$ Smith, p.162; Peter Franks, personal correspondence, 1 April 2019; Boraman, "The Independent Left Press and the Rise and Fall of Mass Dissent in Aotearoa since the 1970s," p.45.

${ }^{19}$ Smith, pp.162-3; Peter Franks, personal correspondence, 1 April 2019.

${ }^{20}$ Simon Wilson, interviewed by Max Nichol, 8 December 2018.
} 
Salient had close ties to MILO and its antecedent groups and was influenced by these Maoist Marxist-Leninist ideas. Franks was a founding member of MILO. He had been exposed to socialist ideas during debates on whether the anti-Vietnam war movement should simply oppose foreign involvement in the war or actively support the Vietnamese National Liberation Front, a Marxist-Leninist organisation. Franks had come down on the side of the latter. From these debates, he and other like-minded students began to associate with the expelled, Maoist-aligned Wellington members of the CPNZ. Though his politics at that time were broadly underpinned by Maoism, this was not the only thing informing his views: "I was twenty-two ... I was still really finding my way, I wouldn't think I ... necessarily had a completely well thought out philosophy ... I didn't see Salient as being a Maoist newspaper". ${ }^{21}$ Fellow MILO member Robert Reid likewise emphasised the multitude of experiences which had informed his politics, saying that "it's a whole mixture of your background, of what you study and the people that you are working with because what you think is right or correct". ${ }^{22}$ Salient also carried reports from delegates on NZUSAsponsored trips to China. ${ }^{23}$ Franks was one such delegate in 1973. He described interactions with government officials and ordinary people who convinced him that Chinese communism was excelling while other communist states had failed. ${ }^{24}$

Steele did not align himself with any particular doctrine of socialism. His understanding of socialism and his opposition to capitalism was more intuitive. It was not based on careful study of the canonical texts of socialism - he "never read them then" and he's "never read them since" but rather on his own personal experiences as a worker. He encountered poor wages and working conditions while employed variously as a truck driver, a stevedore, and a hay-bailer, lending him "an instinctive grasp of the oppression of the working classes". His politics were described by others as anarchistic, a label which he felt was "probably not too far from the truth". Nevertheless, he had a strong respect for the Maoist-aligned socialists on campus. He believed they had the clearest and most convincing class analysis out of the various socialist collectives on campus. ${ }^{25}$ This included other MILO and Paper Collective members such as Terry Auld and Mike Law. Both were contributors to Salient. Auld in particular was deeply involved in MILO. Though he totally

\footnotetext{
${ }^{21}$ Peter Franks, interviewed by Max Nichol, 20 December 2018.

22 Robert Reid, interviewed by Cybèle Locke, 27 January 2015.

${ }^{23}$ For more information on the nature and purpose of these trips, see Shaw, "Telling the Truth About People's China."'

${ }^{24}$ Peter Franks, 'Report from China', Salient, Vol 36, No 16, 1973, p.1.

${ }^{25}$ Roger Steele, interviewed by Max Nichol, 16 December 2018.
} 


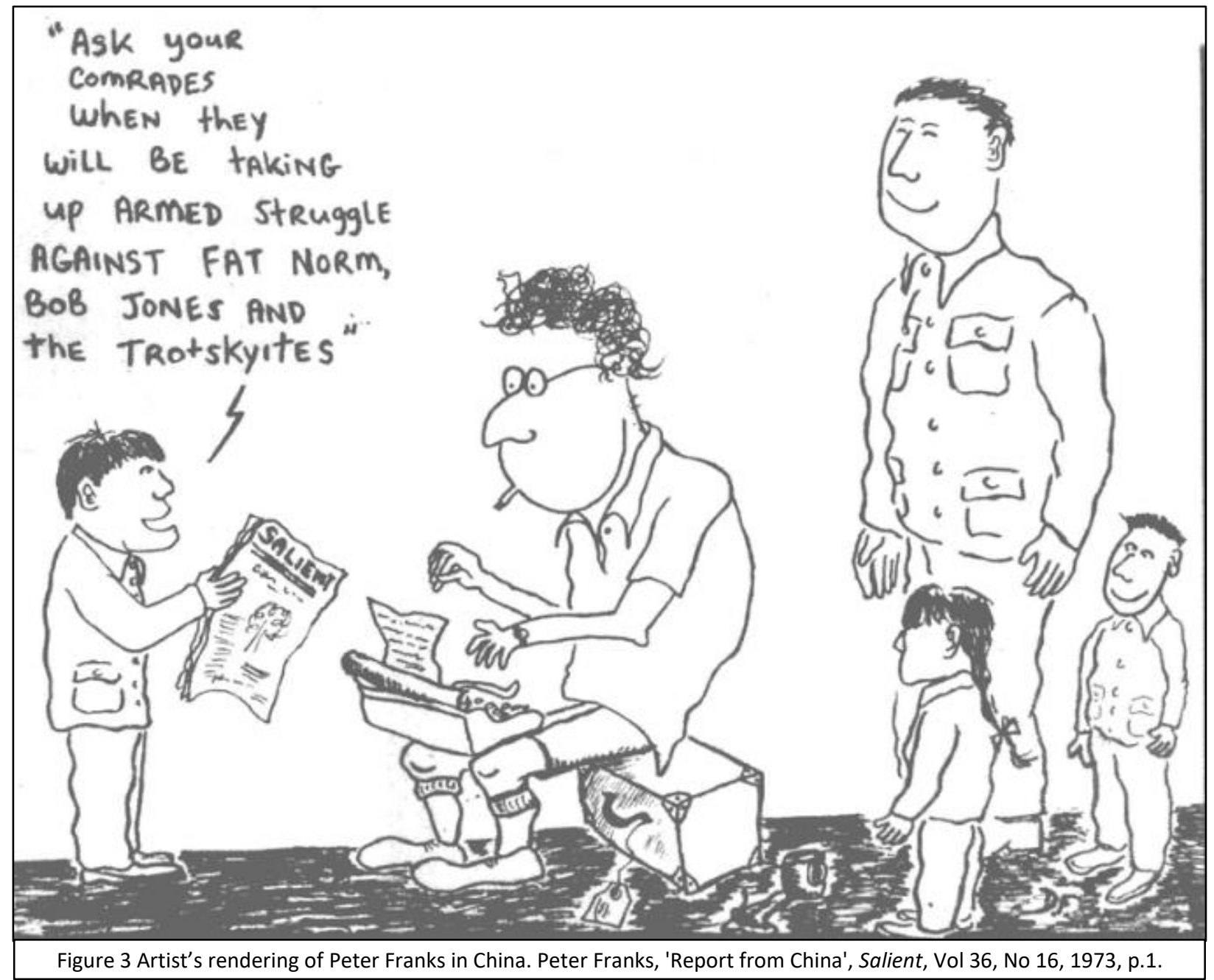

renounced socialism in the 1980s, while he was involved with MILO he was, according to Smith, the organisation's "most prolific writer and dominant leader, with absolute, dogmatic certainty in Marxism". ${ }^{26}$ Auld contributed regularly to Salient in the 1970s. Many of his pieces reflected his alignment with Mao's China, such as a number of features on the spread of Soviet imperialism. ${ }^{27}$ Though, as Franks said, Salient was not a Maoist newspaper, it certainly had Maoist contributors and content.

The influence of socialist ideas had a significant effect on the political direction of Salient, the analysis it presented, and the type of content it published. The outlook of the socialists involved in Salient was not necessarily revolutionary - few believed that the conditions were right for a

\footnotetext{
${ }^{26}$ Smith, Working Class Son, p.164.

${ }^{27}$ Terry Auld, 'Soviet Union Capitalist ... and Imperialist', Salient, Vol. 39, No. 20, 9 August 1976, pp.14-15; Terry Auld, 'War Clouds over the Horn of Africa', Salient, Vol. 40, No. 23, 12 September 1977, p.13; Terry Auld, 'Russian expansionism in Africa: Eritrea next', Salient, Vol. 41, No. 9, 24 April 1978, pp.10-11.
} 
total socialist revolution in New Zealand. ${ }^{28}$ Boraman asserts that generally speaking, the direct action which followed 1968 "achieved many gains and reforms" while "never really seeking revolutionary change". ${ }^{29}$ Alternative media reflected this, taking a primarily activist role with fewer publications advancing an intellectual, theoretical approach to affecting social change. Generally, this activist role was performed by Salient. As Steele explained, his involvement in Salient was "inseparable from protest". Much of the reporting about protest in Wellington in Salient while he was editor was attained by gathering a group of staff, throwing their placards in the back of the Salient van, and driving to wherever the protest was taking place. ${ }^{30}$ Afterwards, someone would either volunteer to write about the demonstration, or someone would be asked to do so. This element of Salient's content also extended to organising protest. Through the newspaper, students were alerted to the when, where, and why of upcoming protest action (see Figure 4).

This also included reporting on political developments overseas, with particular attention to attempts to establish communism in foreign states. In setting Salient's political agenda for 1975, editor Bruce Robinson wrote:

New Zealand has sent troops to Malaysia to kill Malaysians, to Vietnam to kill Vietnamese and to Korea to Kill Koreans. They weren't wanted by these people but the United States and the British needed New Zealand's services ... We have then a strong interest in understanding what's going on underneath the confusion of the current world situation and at least a pragmatic interest in starting to associate with the ascendant forces. ${ }^{31}$

When the third Labour government, led by Norman Kirk, was elected in 1972, Kirk swiftly pulled New Zealand's military presence from Vietnam, granting a major victory to the anti-war movement. ${ }^{32}$ Salient continued to report on the Vietnam War, focusing on the tension between the repressive, US-backed Thieu regime in South Vietnam and the quest for communism in North Vietnam. ${ }^{33}$ Salient also expressed support for socialists in Chile, and advocated on behalf of Malaysian students in New Zealand who had criticised the Malaysian Government and been

\footnotetext{
${ }^{28}$ Roger Steele, interviewed by Max Nichol, 16 December 2018.

${ }^{29}$ Boraman, "Revisiting the Global and Local Upheavals of 1968," p.54.

${ }^{30}$ Roger Steele, interviewed by Max Nichol, 16 December 2018. There was even a Salient song they would sing while driving to demonstrations: "When the shit hits the fan / We'll be there in the van / We'll be there in the Salient van".

${ }^{31}$ Bruce Robinson, 'Editorial', Salient, Vol. 38, No. 4, 26 March 1975. Robinson was appointed as editor for 1975 from the fourth issue onwards, following the withdrawal of a trio of co-editors over the summer.

${ }^{32}$ Rabel, New Zealand and the Vietnam War, pp.328-9.

33 'Crutches - Only for Thieu', Salient. Vol. 37, No. 11, 11 May 1974, pp.8-9.
} 


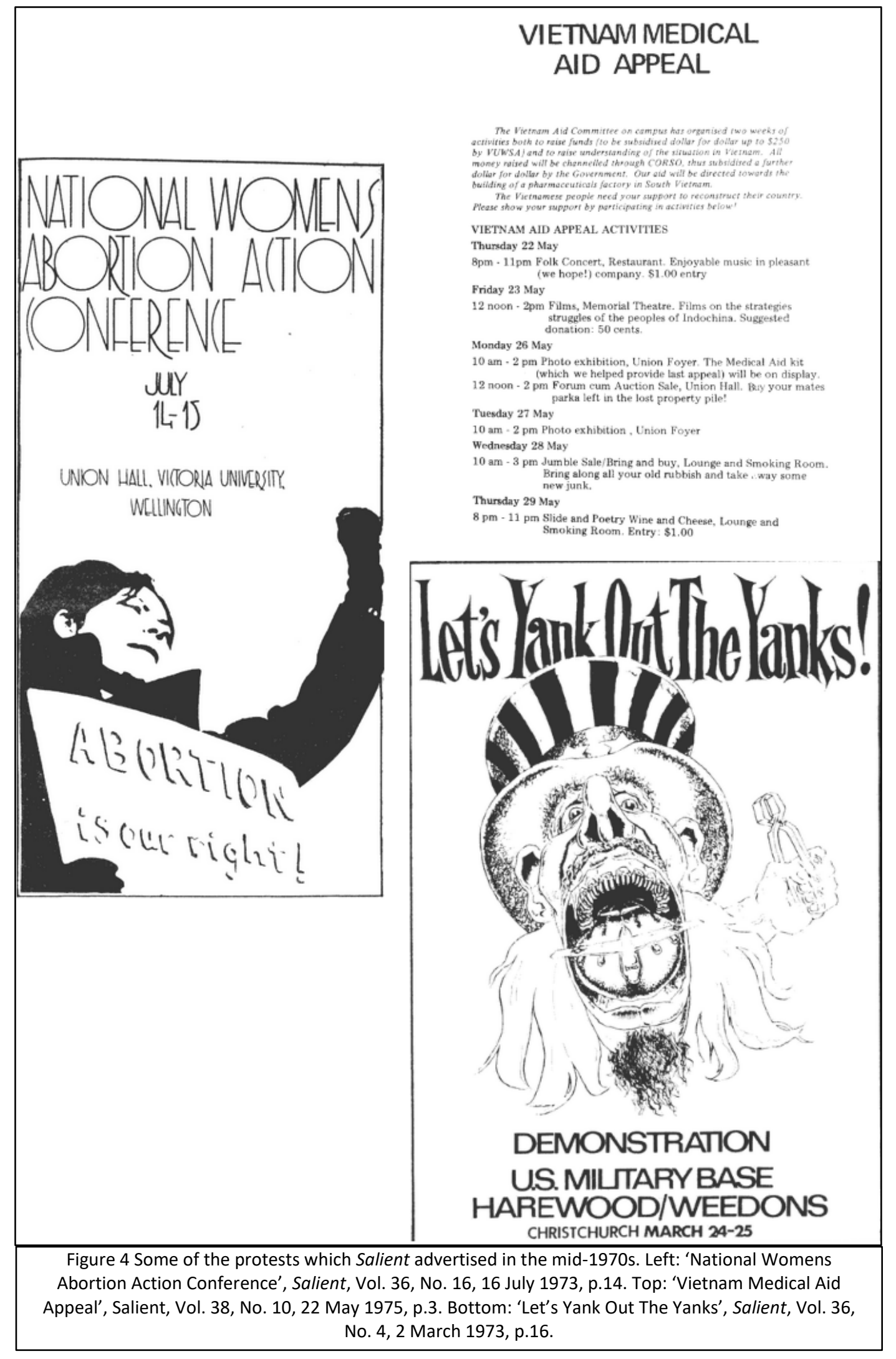


persecuted when they returned to Malaysia. ${ }^{34}$ In these ways, the activism and politics of Salient's editors engaged in outside of the newspaper were reflected in its content.

Class was the central analytic of Salient's editors. The oppression of the working class, the excesses of capitalism, and class struggle regularly framed issues in Salient. A guest editorial written by Karl Marx himself (in the form of an extract from Theories of Surplus Value) was one of the more on-the-nose expressions of this socialist influence. ${ }^{35}$ Salient's analysis of the poor state of the rental housing market in New Zealand levelled that it was a symptom class warfare enacted by landlords against their tenants. Steele wrote that the solution was to "do away with landlords altogether ... As long as housing is regarded not as a basic right but as fair game for profit there will always be exploitation, sub-standard conditions, evictions and all the other related evils of a system that allows a wealthy minority class of parasites to live at the expense of the majority". ${ }^{36}$ Salient even had a direct involvement in a stand-off with infamous Wellington landlord Madhav Rama which involved "liberating” the possessions Rama had seized from evicted tenants following a rent-strike against his properties. ${ }^{37}$ Along similar lines, when Salient reported on a new campus group that encouraged recycling, reporter David Tripe queried "why should we have to buy all this junk that needs to be-cycled anyway? Again, the issue is one of profits. To make profits ... the producer must be able to sell as much as he can at the price he gets for his product". ${ }^{38}$ This framing of issues around class discourse was common in Salient. These kinds of example demonstrate how class struggle and anti-capitalism were central pillars in Salient's reporting.

Related to this socialist and class-based analysis was Salient's support for militant trade unionism. A report on the dispute between the Coachworkers' Union and Ford and General Motors in 1974 explained the value of trade unions succinctly to Salient's readers. Not only did they help workers achieve better conditions, but "they also help workers to realise that it is possible to stand up against the economic power that controls their lives. Every industrial struggle also indicates the

\footnotetext{
34 'Silence and cries the echoes of my song', Salient, Vol. 38, No. 14, 20 June 1975; Don Carson, 'Malaysians to fore in Protest', Salient, Vol. 37, No. 15, 3 July 1974, p.5.

${ }^{35}$ Karl Marx, 'Guest Editorial', Salient, Vol. 36, No. 8, 19 April 1973, p.10.

${ }^{36}$ Roger Steele, 'Capitalism causes the problems: Making housing an election issue', Salient, Vol. 37, No. 24, 18 September 1974, p.1. This was a consistent area of political advocacy for Steele. He worked for the Tenants' Protection Agency after departing Salient in 1974.

37 'The Strike Goes On... And On', Salient, Vol. 36, No. 8, 19 April 1973; Peter Franks, interviewed by Max Nichol, 20 December 2018.

${ }^{38}$ David Tripe, 'Ecology Action: Are they Wasting their Energy?', Salient, Vol. 36, No. 4, 21 March 1973, p.10.
} 
class struggle in our society". ${ }^{39}$ Both Labour and National engaged in the maligning of unions at this time. ${ }^{40}$ As Robinson explained ahead of the 1975 election, "the state serves the same master regardless of who is in Parliament. In the struggle of employer against employee the state stands ready to serve the employer's interests". ${ }^{41}$ As organisations directly advocating on behalf of the working class and standing up to employers and the Government, supporting trade unions was an expression of Salient's anti-capitalist, class-based politics.

The foregoing demonstrates that much of Salient's political content pertained to reporting on, organising, and contextualising protest and political issues in the early 1970s. This supports Boraman's contention that "leftists put most of their energy into activism rather than writing" to the detriment of a strong analytical, intellectual left press which advanced theory as well as activism. ${ }^{42}$ However, the connection between MILO and Salient meant that many editors and contributors' writing was influenced by Maoist theoretical analysis. Their writing had more of an analytical intention. Auld and Law provided socialist analyses of the New Zealand political situation, drawing on instances of international socialism and placing New Zealand within this context. A 1973 feature by Law for example discussed the attempts by the government to discredit and weaken trade unions, first foregrounding the state of international capital and New Zealand's participation in its institutions like the World Bank and the International Monetary Fund. ${ }^{43}$ Salient would also occasionally take articles from overseas publications and re-apply their analysis and conclusions to the New Zealand context. ${ }^{44}$

Salient also reported on the issue of foreign control over the New Zealand economy. Robinson was a particular proponent of this issue - he became a member of the Campaign Against Foreign Control in New Zealand in 1976 and wrote about Soviet Union, Japan, South Korea, and Taiwan encroachment on New Zealand's fishing stocks for Salient. ${ }^{45}$ This analysis had a nationalist bent, similar in some ways to Bruce Jesson's development of a nationalist-socialist theory for New Zealand in his journal, the New Zealand Republican. Indeed, in 1975 Robinson

\footnotetext{
39 'Behind the dispute at Fords and G.M', Salient, Vol. 37, No. 23,

40 Bodman, "The Public Have Had a Gutsful and So Have We' 1968-1984," p.12.

${ }^{41}$ Bruce Robinson, 'Editorial: National's policy on unions', Salient, Vol. 28, No. 18, 23 July 1975, p.2.

42 Boraman, "The Independent Left Press and the Rise and Fall of Mass Dissent in Aotearoa since the 1970 s," p.33.

${ }^{43}$ Michael Law, 'Keeping Workers in their Place', Salient, Vol. 36, No. 4, 2 March 1973, pp.8-9.

${ }^{44}$ Roger Steele, interviewed by Max Nichol, 16 December 2018.

${ }^{45}$ Bruce Robinson, 'Fighting Foreign Control', Salient, Vol. 39, No. 16, 12 July 1976; Richard Bohmer and Bruce

Robsinson, 'Our biggest natural resource .... Down the Drain?', Salient, Vol. 40, No. 7, 13 April 1977, pp.6-7.
} 


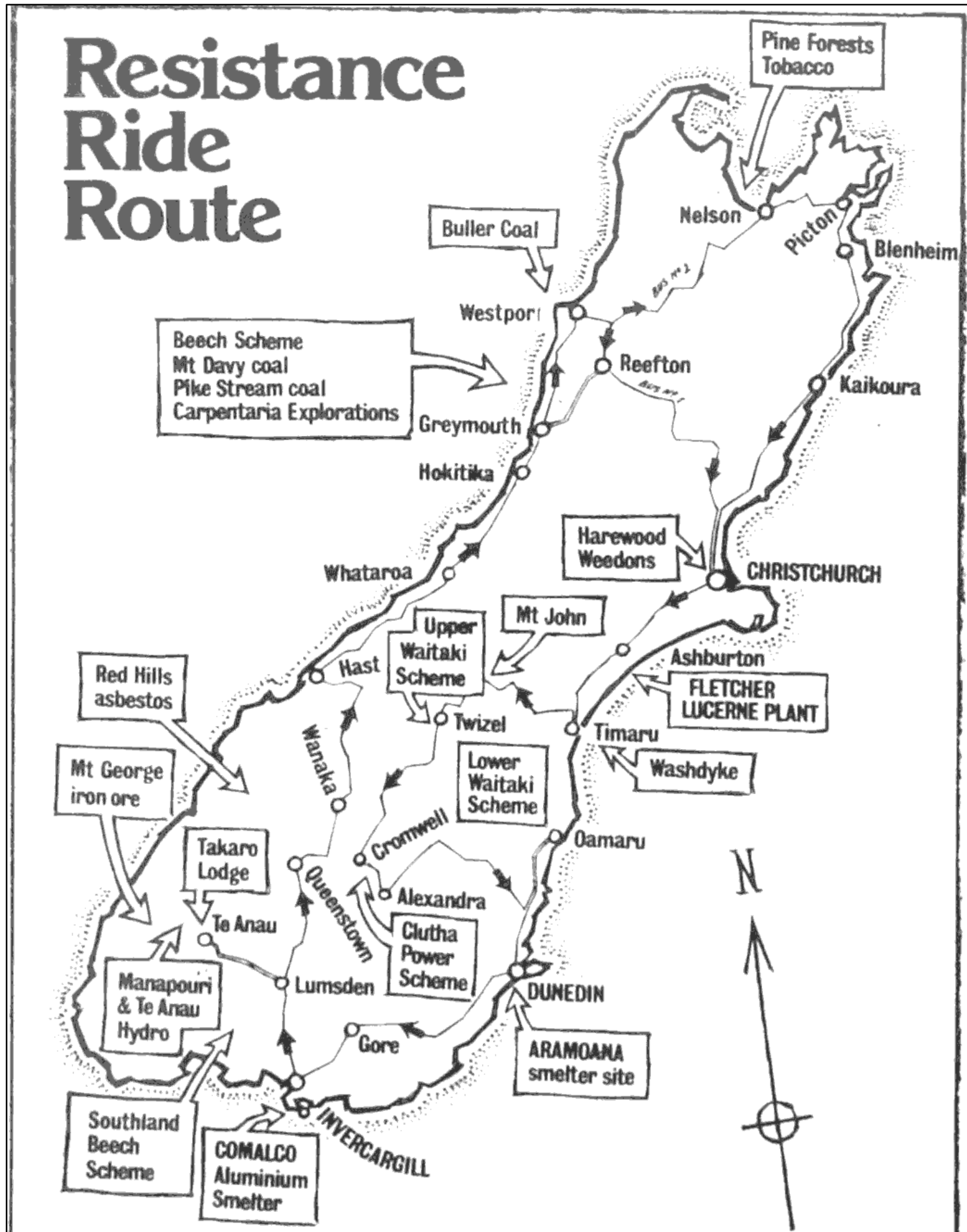

Figure 5 The route of the 1975 South Island Resistance Ride. Diane Hooper, 'This Land, Our Land', Salient, Vol. 38, No. 2, 11 March 1975, pp.8-9. 
reprinted a feature by Jesson from the New Zealand Republican, "slightly adapted for Salient", which levelled that Sir Robert Kerridge had established a monopoly over the New Zealand film industry by drawing on the financial backing and the distribution networks of the Rank Organisation, a company based in England. ${ }^{46}$ In the same year, a feature provided a blow-by-blow of the Resistance Ride (Figure 5) a tour of the South Island in which "three farmers, three housewives, four teachers, three journalists, a pensioner and a few dozen other 'average New Zealanders" visited the sites of "many of the most blatant and newsworthy examples of foreign control in the country". ${ }^{47}$ This analysis perhaps lacked the intellectual rigour of Jesson's writing, but it can be seen as part of the same line of questioning about New Zealand's national aspirations. ${ }^{48}$ These examples provide some evidence that while Salient was for the most part an extension and reflection of its contributors protest activities, it also featured some content which sought to analyse and advance understanding of New Zealand's political conditions.

\section{"Not how, but why this university is a failure": Challenging the Elitist University}

An important area to which contributors to Salient applied class-based and socialist analysis in the mid-1970s was the university itself. They contended that universities were elitist, removed from the needs of society and subservient to the interests of the business community. In their opening editorial for 1973, Steele and Franks questioned why "the relations between the university and society in recent years have been in the developing links between the university and the business world ... The only way staff, students, and administrators at this university can make any real contribution to changing it is to get out and work for change in society at large". ${ }^{49}$ This sentiment imagined a university with a different structure and a different relationship to the society in which it existed, in which academics share and apply their knowledge rather than keep it cloistered within the academy.

The nature of assessment and the kind of "intelligence" it measured was also called into question. In a report on the October Club, Patrick Martin explained that "the question of the university's function in society cannot be divorced from the question of assessment and its

\footnotetext{
${ }^{46}$ Bruce Jesson, '.... Kerridge, This is Your Life', Salient, Vol. 30, No. 6, 10 April 1975, pp.8-9.

${ }^{47}$ Diane Hooper, 'This Land, Our Land', Salient, Vol. 38, No. 2, 11 March 1975, pp.8-9.

48 Boraman, "The Independent Left Press and the Rise and Fall of Mass Dissent in Aotearoa since the 1970s," pp.51-2.

${ }^{49}$ Peter Franks and Roger Steele, 'Editorial', Salient, 28 February 1973, p.2.
} 
function". Its function, in his view, was to lead students to an academic concession to the status quo.$^{50}$ Robinson believed in the abolition of assessment entirely. He proposed that assessment "was an integral part of class society" as it measured intelligence by a middle-class yardstick. He reminded students that while they were fighting for improvements in assessment conditions, "we should realize [sic] that the major battle - the abolition of assessment - can only be achieved with the abolition of class society". ${ }^{51}$

Conceptualisation of a major upheaval of university education did translate into some practical action beyond articles in Salient. The October Club aimed to spread socialism on campus, but those gathered at its inaugural meeting decided to place a particular emphasis on addressing the nature of the university itself: "It was agreed that the primary orientation of a student club should be with the university. In the past, most of the political activity on campus has been directed at activities taking place not only outside the university, but usually outside New Zealand as well ... the obvious approach is to look at the problem that students face, and the role of the university. Maybe at that point you can relate these problems to other problems in the wider society". ${ }^{52}$ This approach to university reform integrated socialist analysis with the concerns of students and the university, taking these as a reflection of the social problems which existed under capitalism. It was hoped that this "combination of action and reflection should lead to changes on both the level of structure and consciousness ... The success achieved and the experience and guidelines gained promise well for future action". ${ }^{53}$

Students challenging the structure of universities in New Zealand was not without precedent. In 1968 for example, students at the University of Otago and at VUW demanded, and were granted, student representation within the top levels of the university administration. ${ }^{54}$ These efforts made demands upon existing features of the structure of the university, such as the University Council at VUW. The kinds of ideas put forth in Salient in the mid-1970s went further. Tinkering around the edges of the university would not solve the central problem of its capitalist elitism and disconnection from the society in which it existed. The distinction between prior challenges and these radical ideas about university is well demonstrated by an article from 1973

\footnotetext{
50 Patrick Martin, 'Suffering the obstacle course', Salient, 17 April 1974, p.4.

${ }^{51}$ Bruce Robinson, 'Editorial', Salient, 20 June 1975, p.2.

52 David Tripe, 'October Club: spreading socialism on campus', Salient, 3 April 1974, p.3.

53 Patrick Martin, 'Suffering the obstacle course', Salient, 17 April 1974, p.4.

${ }^{54}$ Elworthy, Ritual Song of Defiance, pp.115-6; Hamilton, A Radical Tradition, p.126.
} 
which considered "Not how, but why this university is a failure ... We have had enough. We want change ... Rather than discussing whether history students should have nine essays or ten ... we must look at the "total absurdity" of the university as it is". University education as it stoof was compared to a nine-to-five office job, described as anachronistic training for "priests, statesmen and lawyers", and generally perceived as out of touch with the needs and realities of "the community". ${ }^{55}$

This critique of education was an area which Australian students were also immersed in. As Hannah Forsyth explains, Australian radical students in the 1970s identified universities as sites of class division, inextricable from the capitalist societies in which they were embedded. For example, the Adelaide Students for Democratic Action group "were prompted to declare they stood for 'the destruction of this university [and] the destruction of the social system to which the university is a willing boot-licker". ${ }^{56}$ As in New Zealand, these students called for either the abolition of assessment or a reorientation of assessment around encouraging "individual empowerment rather than function as an instrument of obedience to norms dictated by universities". ${ }^{57}$ In both contexts, students were picking up the ideas of Brazilian theorist Paulo Freire who felt that "traditional pedagogical formulation not only reflected society's oppressive structures but also reinforced them". ${ }^{58}$ Salient reported on Freire's visit to New Zealand in 1974, providing details of a weekend workshop held in Auckland. Though the reporter found the workshop "disappointing" in that Freire's more challenging ideas were not understood by most of the attendees, she also took away that "it hardened our impatience at an academic, predominantly verbal way of experiencing reality- as opposed to an active experiencing mode coupled with reflection". 59

Implementing the more radical ideas associated with this critique of universities met with little success. While the suggestion that assessment be abolished had some proponents, it was not endorsed by the majority. At NZUSA's May Council of 1975, Salient reported that "a rather anarchic idea stemming from the Australian Union of Students abolishing assessment was considered, but the rather more sensible idea of opposing assessment when it interferes with the

\footnotetext{
${ }^{55}$ Brendan Smith, 'The Continuing Story', Salient, 6 June 1973, p.5.

${ }^{56}$ Hannah Forsyth, "The Ownership of Knowledge in Higher Education in Australia 1939-1996" (PhD Thesis, University of Sydney, 2012), p.155.

${ }^{57}$ Forsyth, pp.156-7.

58 Forsyth, p.150.

59 Mary Slater, 'A weekend with Paulo Freire', Salient, Vol. 37, No. 11, 11 May 1974, pp.4-5.
} 
teaching process was agreed upon". ${ }^{60}$ Indeed, while the representatives of the Australian Union of Students were united in their position that assessment was simply a means of testing how well students could cram prescribed sets of information, "only a minority felt that there should be none". ${ }^{61}$ Nevertheless, the presence of these ideas in Salient were an application of its editors' class-based, anti-capitalist analysis to the immediate context of the university. Steele felt there was a general belief that the university was not "acting as a critic and conscience so we had to be the critic and conscience of the university". ${ }^{62}$ Salient's reporting on universities in the second half of the 1970s began to focus more heavily on the material conditions of study, particularly inadequate tertiary education funding and student bursaries. These shifts in the debate on the politics of education will be discussed below.

\section{Women's Liberation in Salient}

Salient's coverage of women's issues in the 1970s followed the general contours of the wider Women's Liberation Movement. In the 1970s, “novel forms of organising and protest emerged to highlight the position of women, both Pākehā and Māori, in New Zealand society”. ${ }^{3}$ This movement was determined not to be "content with minor aims ... [arguing] for the removal of all discriminatory social practices that confined women". ${ }^{64}$ Women students were galvanised by the protest action of the late 1960s and early 1970s while at university, but also gained an awareness of the gender inequality which permeated New Zealand society. ${ }^{65}$ Frustrated that her male contemporaries in the VUW Socialist Club were "not addressing the needs of women", Therese O'Connell founded the Wellington Women's Liberation Front at VUW in $1970 .{ }^{66}$ O'Connell's group was renamed the University Feminist Organisation in 1973 and published a semi-regular column in Salient in 1973 and 1974 titled “Up From Under!”. Consistent with the general political direction of Salient, the group had a socialist feminist line of analysis, maintaining that women would only be "truly liberated ... by both cultural and economic reform" brought

\footnotetext{
60 'What Was Decided', Salient, 22 May 1975, pp.10-11.

${ }^{61}$ Forsyth, "The Ownership of Knowledge in Higher Education in Australia 1939-1996," p.157-8.

62 Roger Steele, interviewed by Max Nichol, 16 December 2018.

${ }^{63}$ Barbara Brookes, A History of New Zealand Women (Wellington: Bridget Williams Books, 2016), p.338.

${ }^{64}$ Brookes, p.337.

${ }^{65}$ Brookes, p.337.

${ }^{66}$ Dann, Up From Under, p.5.
} 
about by an end to patriarchal capitalism. ${ }^{67}$ The column was a space for the University Feminists to spread their views, in conjunction with their wider activities. ${ }^{68}$

Throughout the 1970s, Salient captured the multi-issue nature of the Women's Liberation Movement. The right to equal pay, to legal and safe abortions, to contraception, to equal distribution of domestic labour, and an end to day-to-day sexism were some of the main issues which a young generation of women demanded action on. ${ }^{69}$ It was these issues that the University Feminist Organisation identified as important in 1973, and they were carried forward. ${ }^{70}$ Women contributors to Salient and student politicians such as Lamorna Rogers, Leonie Morris, Lindy Cassidy, and Rire Scotney (the daughter of Salient's founding editor), among others, reported on developments on these issues and the Women's Liberation Movement more generally. Abortion was a particularly prominent issue in Salient, with reporters coming down strongly in favour of safe, legal abortions being a right for all women. Those few in opposition could be found on the letters page. ${ }^{71}$ The Royal Commission on Contraception, Sterilisation and Abortion of 1976 was a landmark in this debate. Salient published the text of the Women's National Abortion Action Campaign's submission to the Royal Commission as a supplement in April 1976 and encouraged students to oppose the adoption of its recommendations when the Commission published their report. ${ }^{72}$ The front page story of issue fifteen for 1977 described the Commission's report and another recent report on the Domestic Purposes Benefit as "companion volumes in the story, 'A woman's place is in the home'". ${ }^{73}$ The recommendations of the Royal Commission did become law, severely limiting access to safe abortions in New Zealand - Salient reported that "100 women per week have been flying to Australia for abortions" since the passage of the legislation. ${ }^{74}$

Despite publishing a relatively substantial amount of feminist content, Salient was not a feminist publication. Salient had its first woman editor in 1941. It would be over four decades before its second. In the 1970s, VUWSA had a Woman's Vice-President position, guaranteeing at least one woman on the Executive, and women held the Presidency in 1970 (Margaret Bryson),

\footnotetext{
${ }^{67}$ Brookes, A History of New Zealand Women, p.348.

68 'Up From Under!', Salient, Vol. 36, No. 1, 28 February 1973, p.13.

${ }^{69}$ Pat Rosier, Twenty Years of Broadsheet Magazine (Auckland: New Women's Press, 1992), p.9.

70 'Up From Under!', Salient, Vol. 36, No. 1, 28 February 1973, p.13.

${ }^{71}$ See for example, Vic Urwin, 'More on Abortion', Salient, Vol. 41, No. 5, 27 March 1978, p.15.

72 'Abortion is a Women's Right', Salient, Vol. 39, No. 6, 5 April 1976, pp.12-15.

73 'Attacks On Women', Salient, Vol. 40, No. 15, 4 July 1977, p.1.

${ }^{74}$ Lamorna Rogers, 'Editorial', Salient, Vol. 40, No. 2, 6 March 1978, p.2.
} 
1975 (Lisa Sacksen), and 1977-78 (Lindy Cassidy). But at Salient, every editor in the 1970s was a man, as were many of the technical editors and contributors. There was some pushback against the male left at Salient which demonstrated some of its limitations in analysing gender issues. In 1975 for example, Salient drew criticism for the publication of an ad for bean bags which featured "one of your classic pretty girls draped across it", which some readers felt reinforced the objectification of women in media. The matter was debated at SRC, where one student felt that "Salient was supposed to have a rather more enlightened view of the world" than the ad presented, demanding that Robinson print a front-page apology. Robinson was relatively unrepentant, saying he was "glad of such a reaction, since he'd been quite disappointed that other, far more reactionary “drivel" that he'd put into Salient hadn't even caused a ripple". His response suggests that other material he had published would have been in some way more worthy of the pushback generated by the offending advertisement. Rather than engaging with the possibility that he had indeed made an editorial decision which reinforced sexist representations of women, he seemed not to think it was a particularly important issue.

Along similar lines, in their column the University Feminist Organisation not only rallied against the embedded sexism in New Zealand's patriarchal capitalist society, but its manifestations in Salient more particularly. "One of the real problems of a university feminist group", began one column in 1974, "is that it is forced into a continually defensive stance. Good old male chauvinism is masked behind the 'radical' man who insists that he "agrees with" women's liberation, but spends a lot of time trying to give us good advice". ${ }^{75}$ Salient regular Tripe for example accused the University Feminists of ignoring the needs of working-class Māori women. The University Feminists responded acknowledging that most of their members were indeed middle-class and Pākehā, but that this reflected "our sexist, racist and middle-class-orientated education system" and that they were entitled to liberation just as their "working-class Maori sisters" were. In presuming that the University Feminists should speak for Māori women, Tripe showed "his lack of understanding of the women's liberation (or any other liberation) movement ... The last thing Maori women need is a group of middle-class Pakeha women arrogantly organising a liberation group for them". ${ }^{76}$ Along similar lines, the column responded to Mike O'Flaherty who objected to the movement's fixation on the matter of abortion in an article for Salient, on the grounds that it

\footnotetext{
75 Deborah Jones, 'Up From Under!', Salient, Vol. 37, No. 6, 10 April 1974, p.6.

${ }^{76}$ Fern Hickson, 'Up From Under!', Salient, Vol. 37, No. 3, 20 March 1973, p.8.
} 
would not be relevant to working-class women. To this, Fern Hickson wondered why he "thinks he, as a male, can choose which issues the women's movement should concentrate, and which it should cast aside? Does he consider himself as an expert on women's suffering?". 77

Salient's coverage of the Women's Liberation Movement in the 1970s was consistent and represented the variety of issues which this energetic wave of feminism engaged with. Some symbolic concessions to putting women's voices front and centre also demonstrated Salient's editors' efforts to foreground women's voices. For example, Simon Wilson invited Lamorna Rogers and Leonie Morris to contribute guest editorials in place of his own during the week of International Women's Day in $1978 .{ }^{78}$ However, unlike publications such as Broadsheet, Salient was not produced by and for women, and nor was it expressly intended to have an audience primarily made up of women. The dismissive attitudes of male activists towards Women's Liberation which had prompted the founding of groups such as the Women's Liberation Front were also found in Salient. Contributors writing about women's issues in Salient had to contend with conservative pushback, such as individuals and groups who took a pro-life position on abortion, best represented by Patricia Bartlett and the Society for the Promotion of Community Standards. ${ }^{79}$ They also had to contend with critiques of Women's Liberation from within the left and within Salient itself, demonstrating some of the limits of Salient's predominantly male staff. As Steele notes, "it was a time when Pākehā men felt no compunction, or many of us, speaking about all sorts of issues we should have shut up about and just let people speak themselves, whether that was women or gay or Māori or whatever". ${ }^{80}$

\section{Māori Issues in Salient}

In the 1970s, young radical Māori groups such as Ngā Tamatoa challenged the racism which was embedded in New Zealand society. Ngā Tamatoa called for recognition of the Treaty of Waitangi and revitalisation of te reo Māori, which they argued the Government had deliberately neglected through the policy of assimilation. To some degree, Salient's attitude to Māori issues was influenced by its socialist class analysis. The publication of a submission from the Auckland

\footnotetext{
77 Fern Hickson, 'Up From Under!', Salient, Vol. 37, No. 7, 17 April 1974, p.4.

78 Lamorna Rogers, 'Editorial', Salient, Vol. 40, No. 2, 6 March 1978, p.2; Leonie Morris, 'Editorial', Salient, Vol. 40, No. 2, 6 March 1978, p.12.

79 Brookes, A History of New Zealand Women, p.368.

${ }^{80}$ Roger Steele, interviewed by Max Nichol, 16 December 2018.
} 
Committee on Racial Discrimination in 1974 for example carried the editorial caveat that while Steele was "substantially in agreement with the submissions, I have one point of clarification ... That is, that the problem is not simply one of Pakehas versus Maoris, but rather a certain section of Pakehas who do indeed repress the bulk of the Maori population, but also repress a significant proportion of the Pakehas as well". ${ }^{81}$ Since the 1950s, Māori were closely involved in trade unionism. Following the significant migration of Māori from rural New Zealand to its urban centres, many Māori "chose to cluster in factories, in the Electric Power Board, on the wharf, in freezing works, in certain trucking firms and service sites”. Māori brought to these working-class occupations their own understandings of how to organise within and engage with the workplace, wherein being Māori "informed the practices and values" of work. ${ }^{82}$ In turn, this flowed into trade unionism, through which many Māori workers adopted the politics of their unions, then adapted these ideas to a Māori context. The Māori Organisation on Human Rights for example emerged out of the Wellington Drivers' Union in response to the Māori Affairs Amendment Bill $1967 .{ }^{83}$ This thread of Māori activism within trade unions likely informed Steele's identification of the wealthy (Pākehā) capitalist class as the common oppressor of both the Māori and Pākehā working class.

Trade unions were not the only sites of Māori radicalism in the 1970s of course. Young Māori and Pasifika activists formed Ngā Tamatoa and the Polynesian Panthers, combining their experiences of institutional racism and forced assimilation in New Zealand's urban centres with the forceful ideas of Black Power which Malcolm X and Stokely Carmichael developed in the United States. ${ }^{84}$ Ngā Tamatoa was particularly active in demanding that the Government, having played an active role in the decline of te reo Māori, commit to revitalising the language. ${ }^{85}$ Steele had a close connection to these groups not typical of Pākehā at the time. He explained that while many of his contemporaries in and around Salient supported Māori activists, few had a working understanding of things like marae protocol or had close working relationships with Māori activists. Steele differed in that he was directly involved with Māori students and activists in

\footnotetext{
81 'Education of the pakeha, by the pakeha, for the pakeha', Salient, Vol. 37, No. 15, 3 July 1974, pp.8-9.

${ }^{82}$ Cybèle Locke, "From Human Rights to Māori Sovereignty: Māori Radicalism and Trade Unions, 1967-86," in The Treaty on the Ground: Where We Are Headed, and Why It Matters, ed. Rachael Bell et al. (Auckland: Massey University Press, 2017), p.76.

83 Locke, p.77.

${ }^{84}$ Locke, "Maori Sovereignty, Black Feminism, and the New Zealand Trade Union Movement," p.258.

85 Harris and Williams, "Rights and Revitalisation, 1970-1990," p.359.
} 
Wellington. Hemi Potatau, a Māori reverend and a "kaumātua of the Te Reo Māori Society" on campus took Steele and a handful of other Pākehā, most of whom were Catholic liberationists, under his wing while he completed his Bachelor of Arts in the early 1970s. Potatau taught this group te reo, and within a few months Steele was able to make a "passable whaikōrero", beginning a lifelong relationship with the language. ${ }^{86}$ Through his involvement with the Te Reo Māori Society, Steele and Salient formed connections with Nga Tāmatoa. In 1972, prominent Tūhoe activist and Ngā Tamatoa member Tame Iti attempted to establish a tent embassy on the grounds of parliament alongside Rawiri Paratene, demanding "Māori control of Māori things". ${ }^{87}$ Iti was arrested but managed to negotiate with the arresting officers for a phone call, which he used to phone the Salient office. Steele answered, and headed to parliament to try to advocate on Iti's behalf. $^{88}$

Through Steele, the influence of Ngā Tamatoa and the Te Reo Māori Society was felt in the pages of Salient itself. In 1973 and 1974, Salient published special issues titled Te Ao Marama ("the world of light”) for Māori Language Week, which featured articles addressing the challenges facing Māori, some published in te reo Māori and some in English. Published during Māori Language Week, there was a particular focus on te reo Māori. Steele's editorial for the first Te Ao Marama was titled "Akona te reo Maori, n'est-ce pas?". ${ }^{89}$ It was a phrase borrowed from Potatau which highlighted that due to the priorities of the New Zealand education system, many more Pākehā New Zealanders could understand the French in the title than the Māori. In 1974, he likewise called for Pākehā to learn te reo Māori, writing that historically “'integration' has been a one-way business, and the neglect of the Maori side has resulted in its near extinction. Learning the language is one way for Pakeha to reverse this tendency", 90 The use of a different name, Te Ao Marama, was intended to signal that the publication was handing over Salient's platform in a meaningful fashion - Steele credits the Te Reo Māori Society with the idea, and Ngā Tamatoa with putting the issue of revitalising te reo on the agenda in the first place. ${ }^{91}$ As editor he facilitated this relationship between Salient and Māori student groups. While these special issues did feature content not directly related to Māori, the content which did was ahead of its time for a publication

\footnotetext{
${ }^{86}$ Roger Steele, interviewed by Max Nichol, 16 December 2018.

${ }^{87}$ Locke, "From Human Rights to Māori Sovereignty," p.80.

${ }^{88}$ Roger Steele, interviewed by Max Nichol, 16 December 2018.

${ }^{89}$ Roger Steele, interviewed by Max Nichol, 16 December 2018.

90 Roger Steele, 'Editorial: Te Ao-Marama', Te Ao Marama/Salient, Vol. 37, No. 23, 11 September 1974, p.4.

${ }^{91}$ Roger Steele, interviewed by Max Nichol, 16 December 2018.
} 
which in its regular reporting was not specifically Māori-focused. Steele reflected: at the time, this was a "very bold thing to do". 92

The prominence that Te Ao Marama gave to Māori voices and Māori issues was not continued to the same degree by Steele's successors. Salient published material which expressed solidarity with important flashpoints in Māori activism such as the Māori Land March of 1975, the occupation of Takaparawhā/Bastion Point in 1977 and 1978, and Ngā Tamatoa's direct action against the University of Auckland engineering students' tradition of the "haka party" in 1979. 93 Class-based solidarity with Māori workers continued to be promulgated, and indeed in 1978, many of the Māori voices in Salient were not students but unionists. ${ }^{94}$ But the extent of Steele's personal engagement with Māori students and te reo Māori, and how this was reflected in Salient, was unique to his editorship. ${ }^{95}$

Peter Franks, Roger Steele, and Bruce Robinson all held class-based analyses of New Zealand society. The protest movements of the late 1960s and early 1970s exposed Salient editors to communist and socialist theories, which in turn informed their reporting. Salient editorials and articles on the myriad political and social issues of the day were an extension of their political activity and political views. However, the election of Robert Muldoon's National government changed the nature of the political landscape. Students and unions, both groups Salient represented and advocated on behalf of, came under fire. Post-1975, Salient's editors continued to push support for trade unions and a class analysis. However, they were forced to contend with a flagging economy and a conservative government. As such, while Salient's general political direction remained the same, the ways in which this was expressed were different.

\section{Muldoon and Salient Support for Trade Unionism}

By 1975 the New Zealand economy was in dire straits. A global "commodity boom" had caused rising inflation and the 1973 oil crisis contributed to "global recession ... [and] political and economic instability around the world". The National Party's new leader Robert Muldoon capitalised on the recession, blaming the Labour government's economic policy for New Zealand's

\footnotetext{
92 Roger Steele, interviewed by Max Nichol, 16 December 2018.

93 'Why the Maori Land March?', Salient, Vol. 38, No. 26, 1975, pp.12-13; 'The Last Bastion Point', Salient, Vol. 40, No. 15, 4 July 1977, p.10; Stephen A'Court, 'Racism in Godzone', Salient, Vol. 42, No. 11, 28 May 1979, pp.4-5. ${ }^{94}$ Simon Wilson, interviewed by Max Nichol, 16 December 2018.

95 It was not until 1997 that Te Ao Mārama was enshrined in VUWSA's constitution, obliging Salient to produce a Māori language issue annually. Hamilton, A Radical Tradition, p.212.
} 
poor economic conditions. In the lead-up to the 1975 election, Muldoon promised to mend a "shattered economy". ${ }^{96}$ National also engaged in open hostility towards unions in their election campaign. Robinson assessed that the content of National's labour policy was a "war against the unions". ${ }^{97}$ Muldoon presented industrial relations as "close to anarchy in New Zealand" and trade unionists as selfish, power-bloated "thugs" with no regard for the national interest. ${ }^{98}$ On this platform, National had a convincing victory in the 1975 general election. Holding both the Prime Ministership and the finance portfolio, Muldoon embarked on a programme of economic management and polemical rhetoric which skewered those who did not support him, including both students and trade unions. Salient's editors followed these developments closely, defending and promoting the interests of both students and workers. This meant opposing cuts to universities and bursaries and encouraging their student readership to perform solidarity with unions and workers in the face of a common problem.

In 1976, John Ryall was the first editor of Salient to write into this new political era with an aggressively conservative Government. Ryall's politics and conception of class were derived from his Catholicism and liberation theology, particularly his involvement with the Young Catholic Students in Wellington in the early 1970s. While at VUW, he was involved in the October Club where he encountered debates between communist groups. However, unlike his predecessors, he found the ideological disagreements, such as the animosity between Salient and the Young Socialists, "fruitless". ${ }^{99}$ In his inaugural editorial, he wrote that "Salient's role has been to keep pushing the "correct line" until those who dare to rebel are so tired of fighting that they submit. ... You either accept the analysis and become a radical, or reject it and become a reactionary ... Salient in 1976 is opening up". 100

Despite having a different genesis for his socialist views, Ryall shared his predecessors' support for trade unionism. Ryall was exposed to trade unions while working in the car plants in

\footnotetext{
${ }^{96} \mathrm{Jim}$ McAloon, Judgements of All Kinds: Economic Policy-Making in New Zealand 1945-1984 (Wellington: Victoria University Press, 2013), pp.152-4, 158.

${ }^{97}$ Bruce Robinson, 'Editorial: National's policy on unions', Salient, Vol. 38, No. 18, 23 July 1975, p.2.

${ }^{98}$ Bodman, "The Public Have Had a Gutsful and So Have We': The Alienation of Organized Labour in New Zealand, 1968-1975," p.100.

99 John Ryall, interviewed by Cybèle Locke, 17 December 2014.

100 John Ryall, 'Editorial', Salient, Vol. 39, No. 1, 1 March 1976, p.4. Ryall made good on this intention, publishing substantial articles from members of the Young Socialists which openly criticized the Maoist position. As discussed in Chapter One, this kind of content was only very rarely published by his predecessors and successors.
} 
the Hutt Valley prior to studying at VUW. ${ }^{101}$ He recognised the threat Muldoon posed not only to students, but to unions and workers as well. Through Salient, he sought to instil in VUW students the idea that their fortunes were intertwined with those of trade unions. Students would need to "stand with organised labour ... If we do not stand firm now then when we next march for the maintenance of our bursary levels we may find blank stares greeting our cries for fraternal support". ${ }^{102}$ The need for students to practice solidarity was particularly important given past failures to do so. In 1976, “A Union Delegate” issued a challenge to Salient's readers: "Where will students stand in the workers' struggle against the employing class and this government? In the past, the majority have either acted as scabs and strike-breakers ... Workers and students, and other classes in New Zealand, should unite to resist Muldoon's economic policies". ${ }^{103}$ In his editorial for the following issue, Ryall likewise reminded students that "during the depression [of the 1930s] students played their part riding on horseback clubbing down the unemployed workers' riots, and have stood on the side of the government and employers in years following. In 1974, students again hit workers over the head when they denied the right of workers to strike, by supporting the issuing of injunctions against unions". ${ }^{104}$ Calls for an alliance between students and worker in the late 1960s and early 1970s were only moderately successful. The alliances which were formed generally did not to move beyond turning out for protests. ${ }^{105}$ However, Ryall's messaging to students that unions, workers, and students were all under fire rhetorically and financially from Muldoon showed a renewed interest in developing solidarity between these groups.

Salient carried this message of solidarity forward in the following years. David Murray became editor in 1977. As a MILO member, he returned Salient to a Maoist and anti-Trotskyist political direction, but maintained the close support for trade unionism. He predicted that it would be a particularly active year for industrial action due to the passage of the Industrial Relations

\footnotetext{
101 John Ryall, interviewed by Cybèle Locke, 17 December 2014.

102 John Ryall, 'Editorial: National's Attack on Students', Salient, Vol. 39, No. 14, 5 July 1976, p.4.

${ }^{103}$ A Union Delegate, 'Unionist Says: We need more money - Make the rich pay', Salient, Vol. 39, No. 12, 7 June 1976, pp.4-5.

104 John Ryall, 'Editorial', Salient, Vol. 39, No. 13, 1976, p.4. The events Ryall is referring to here are likely related to the imprisonment of Bill Andersen, a prominent unionist in the Northern Drivers' Union. He was arrested an incarcerated in 1974 after the NDU ignored an injunction preventing them from engaging in industrial action in solidarity with the Seamen's Union. See Bodman, 'The Public Have Had a Gutsful and So Have We', pp.78-9. 105 Boraman, "A Middle-Class Diversion from Working-Class Struggle?,” p.215. Indeed, Boraman cites a Salient article from 1969 which claimed that amongst students and workers "all that has been created is a friendly sentiment between the left-wingers on both sides, and a feeling that if you ring Salient three hours before a trade union demo you'll get five hundred students on the dot".
} 
Amendment Act late in 1976. Murray believed the implications of the legislation were "not, perhaps, something that students can fully appreciate, until, that is, they go out to work" and that accordingly it was "imperative that students familiarise themselves with the subject" ${ }^{106}$ This solidarity flowed both ways. Ken Douglas of the Federation of Labour spoke at a demonstration on bursaries in August 1977, where he likened the reduction of bursary levels to the "overall reduction in the living standards of workers, farmers, and small businessmen". ${ }^{107}$ Murray was succeeded in 1978 by Salient editor Simon Wilson. Wilson's first exposure to student activism had been at secondary school. At Onslow College in Johnsonville he was part of an actively antiestablishment cohort, which demanded student representation within the school and an end to school uniforms. He continued this activism at university, and through attending and helping to organise protests, he associated with MILO members who eventually invited him to join the organisation. ${ }^{108}$

Support for trade unions did have direct relevance to students, many of whom experienced the conditions of industrial work. It was common for students to work in industrial jobs over the summer holidays to supplement their bursary payments. Unemployment increased in the late 1970s, making this work more difficult to find. At the beginning of 1978, Salient reported that whereas in 1976 there were thirty-seven students registered as unemployed over summer in Wellington and the Hutt Valley, there had been 200 in the summer just gone. ${ }^{109}$ At the same time, the stagnancy of the value of the bursary as government expenditure on education decreased meant scarce work was needed more than ever. At the end of the academic year Salient warned of the scarcity of summer work, gave advice on how to find work and, failing that, what level of benefit students were entitled to from the Department of Labour. ${ }^{110}$

Salient was aware that this scarcity would tempt students to scab on workers. The likelihood of this occurring was particularly high given the prevalence of industrial action in the late 1970s. According to Ryan Bodman, over 370,000 work days "were lost to industrial stoppages" between 1976 and 1980. ${ }^{111}$ Salient editor Peter Beach expressed his solidarity with

\footnotetext{
106 David Murray, 'Industrial disputes a-comin", Salient, Vol. 40, No. 8, 18 April 1977, p.4.

107 David Murray, 'Editorial', Salient, Vol. 40, No. 2, 8 August 1977, p.4.

108 Simon Wilson, interviewed by Max Nichol, 8 December 2018.

109 Lindy Cassidy, 'President', Salient, Vol. 41, No. 1, 27 February 1978, p.2.

${ }^{110}$ Gyles Beckford, 'Vacation Work, Christmas 1976', Salient, Vol. 39, No. 24, 27 September 1976, p.2; 'Welfare

Notices', Salient, Vol. 41, No. 25, 25 September 1978, p.13.

${ }^{111}$ Bodman, "'The Public Have Had a Gutsful and So Have We' 1968-1984," p.34.
} 
trade unions through a special report in support of the 1979 General Strike. Like his predecessors, he was a member of MILO, which following a merger with the Northern Communist Organisation became the Workers' Communist League (WCL). ${ }^{112}$ While the General Strike was not universally observed, it drew a massive turnout. The loss of productivity was estimated at "half a million working days". ${ }^{113}$ Beach's editorial noted that he and the regular Salient staff had observed the strike, leaving the office vacant on Thursday 20 September $1979 .{ }^{114}$ The issue implored students to "understand the struggles of the workers, join unions, and not be fooled into scabbing on the workers should the possibility arise. Unions have supported students in the past and we must stand with them now". ${ }^{115}$ The following year, Salient again encouraged students to both join their relevant union while working over summer, and to resist the temptation to provide scab labour during industrial action. Not only would the practice contribute to students' poor reputation amongst trade unions, but when "you scab on a union you are also scabbing on your fellow students. You are placing at risk their future jobs and their future trade union support". ${ }^{116}$

What was informing Salient's expressions of solidarity with trade unions? It was partly the common enemy in Muldoon. As is explored in more depth below, students mounted opposition to Muldoon's undermining of the value of the bursary and funding for universities. But it was also a function of successive Salient editors having close and enduring ties to trade unions in Wellington. As has been noted, this was a period of significant activity for trade unions. Salient's editors were not simply observing and supporting this action from afar, they were directly involved in it. Ryall for example returned to the car plants after completing his degree and leaving Salient, but maintained a relationship with the newspaper. When a pamphlet needed to be created to inform

\footnotetext{
112 Hamilton WCL had ties to the Waikato University Students' Association. Smith, Working Class Son, p.162; Chamberlain, Constant Radical: The Life and Times of Sue Bradford, p.161.

${ }^{113}$ Bert Roth and Janny Hammond, Toil and Trouble: The Struggle for a Better Life in New Zealand (Auckland: Methuen Publications, 1981), p.168. The General Strike was the first of its kind in New Zealand. It was prompted by the Government's decision to directly intervene in the drivers' award negotiations, threatening to lower the agreed upon pay increase of $11 \%$ to $9.5 \%$ through the use of the Renumerations Act.

114 Peter Beach, 'Editorial Note', Salient, Vol. 42, Special General Strike Issue, 24 September 1979, p.4. This special general strike issue was short, running to just four pages. Salient had not been planning to publish an issue that week at all due to budgetary restraints near the end of the year, but did so to show solidarity with striking workers. 115 Kathy Jamieson, 'General Strike: The Next Step', Salient, Vol. 42, Special General Strike Issue, 24 September 1979, p.3.

116 'Students and union labour: Should Students Join Unions?', Salient, Vol. 43 No. 26, 6 October 1980, p.12.
} 
workers of an upcoming strike, he called on his contacts at Salient to have it typeset and designed using Salient's equipment. ${ }^{117}$

MILO continued to influence the Salient office. MILO was a small organisation - Simon Wilson estimated there were less than fifty members while he was at Salient - but it held "significant influence" over both the VUWSA Executive, Salient, and to some degree the NZUSA National Office. ${ }^{118}$ MILO was always looking to place its members within the institutions of student politics. It was through this influence that Wilson was able to secure the Salient editorship, having expressed an interest in the position through the MILO grapevine. Not every contributor to Salient was a MILO member in the late 1970s of course. ${ }^{119}$ Nevertheless, those who were members "organised as a Salient cell", meeting for discussion and monitoring the individuals coming in and out of the Salient office to sound out potential recruits to the organisation. As Wilson explained, "the theory was we were meant to grow - it's really hard to grow". ${ }^{120}$ In effect, the MILO members of Salient were using the paper and its office to present their agenda and grow the ranks of the organisation.

It was this substantial influence of MILO within Salient which mediated many of its connections to Wellington trade unions. Wellington MILO was active and influential in Wellington Trades Hall, where it had "the leading hand" in its relationships with prominent unionists, such as Pat Kelly and Graeme Clark, the latter of whom was in fact a MILO member. ${ }^{121}$ It was also involved in the "turn to industry" in which student members, after leaving university, would work amongst the working class to gain an understanding of their conditions as well as organise industrial action and boost union support. ${ }^{122}$ This was not unique to MILO - the Socialist Action League also engaged in this praxis in the 1970s. ${ }^{123}$ It is important to note as well that Ryall, though he was not a member of MILO or a Maoist, pushed much the same kind of support for

\footnotetext{
117 John Ryall, interviewed by Cybèle Locke, 17 December 2014.

118 Lisa Sacksen for example was both NZUSA President and a member of MILO.

${ }^{119}$ Wilson estimated that roughly a quarter of the contributors to Salient during his year as editor were MILO members.

120 Simon Wilson, interviewed by Max Nichol, 8 December 2018.

${ }^{121}$ Simon Wilson, interviewed by Max Nichol, 8 December 2018; ; Peter Franks, personal correspondence, 1 April 2019.

${ }^{122}$ Gerard Couper, 'There you go, bringing class into it again', Salient, Vol. 40, No. 4, 21 March 1877, p.7; Boraman, "A Middle-Class Diversion from Working-Class Struggle?," p.215.

${ }^{123}$ Roger Steele, interviewed by Max Nichol, 16 December 2018.
} 


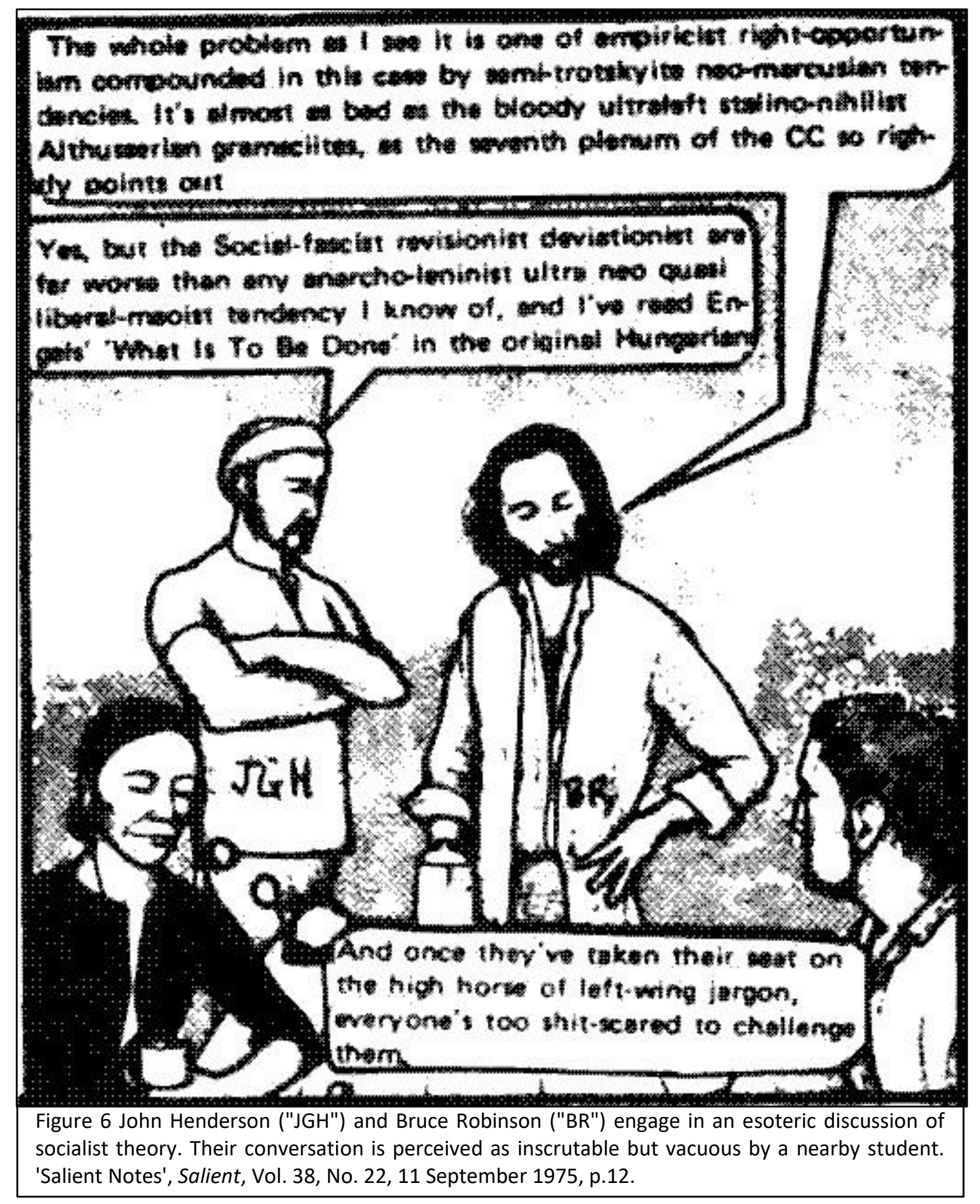

trade unions as did Salient's MILO editors. All deployed Salient as a mouthpiece of union support, often framing this support in a context relevant to their readers - that is, encouraging students to see support for trade unions as aligning with their own interests, and to act accordingly.

Though he was a WCL member, Beach was involved in the founding of the Progressive Student Alliance (PSA), a campus group which attempted to advance common leftist interests across the factional divisions at VUW. Beach explained that in the early 1970s, the reasons for these divisions were not always clear to students not aligned with either faction. As a result "the progressive left became more self-centred rather than trying to enlist mass support", with both 
Maoists and Trotskyists tussling amongst themselves at SRC, VUWSA General Meetings, and in the letters pages of Salient. ${ }^{124}$ "The resulting split ... while important, was along fairly intricate lines", alienating students who might otherwise have supported the socialist causes that the campus socialists advanced. Reflecting on the divisions between Trotskyists and Maoists, Simon Wilson felt their shared animosity was mostly arbitrary, based on historical divisions between Trotsky, Lenin, and Stalin. In practice, these divisions had little relevance to either group. The differences in the desired ends and the means of achieving them of were few: "Looking back on it, the animosity between the two sides is absurd ... basically they ... were on the same side". ${ }^{125}$ Indeed, Wilson admired and continues to admire Mike Treen, a prominent member of the Young Socialists and a frequent figure of Salient's antagonism, "but I never told him that [laughs]". ${ }^{126}$ A cartoon from 1975 (Figure 6) featuring Bruce Robinson and Publications Officer John Henderson illustrates well the perception that Salient was run by an intellectual socialist elite.

Divisions amongst the campus left were also a response to a perceived decline in student activism. Whereas Salient and the VUWSA Executive had continued to engage in politics on and off campus, it appeared that students generally no longer had the time or energy to engage in SRC debates and activism as they once had. Murray wrote in his closing editorial that the "thing we battle against here at Salient and wrack our brains in order to find a solution is the nightmare of all student editors - apathy and indifference". ${ }^{127}$ One report from an SRC meeting took an accusatory tone: "You weren't there were you? In fact only about a hundred people were. The other 5,900, having paid their \$37, apparently don't care how it's spent ... Apathy strikes again. 1978 looks like a bad year". ${ }^{128}$ This degree of pessimism was not universal. As NZUSA President Lisa Sacksen saw it in 1977, there was "still a great deal of activity on our campuses", but students lacked the skills of protest which had been gained during the "great upsurge in student activity which occurred between ' 68 and ' 72 ... People coming through now do not have that experience. I don't think that it is because they don't want to fight or struggle .... But they don't know how

\footnotetext{
124 Peter Beach, 'Left at the crossroads', Salient, Vol. 41, No. 18

125 Simon Wilson, interviewed by Max Nichol, 8 December 2018. Peter Franks likewise referred to these divisions when he was at Salient as "childish".

${ }^{126}$ Simon Wilson, interviewed by Max Nichol, 8 December 2018.

127 David Murray, 'Last One', Salient, Vol. 40, No. 26, 3 October 1977, p.4.

128 Jonathon Scott, 'SRC: Should we bomb Tonga?', Salient, Vol. 41, No. 5, 27 March 1978, p.4.
} 
to". ${ }^{129}$ Similarly, Wilson expressed concern that the "level of interest which rises above cynicism is dangerously low"; students still cared about "a large number of issues, but far too few people are prepared to take on any sort of organisational role". 130

Salient identified causes for this apparent apathy. The introduction of internal assessment in the early 1970s proved to be a mixed blessing for students. Internal assessment had increased the average amount of pressure placed on students across the year, rather than front-loading study stress into the exam periods. ${ }^{131}$ Concerns over what this meant for students' education and social lives are well demonstrated in a message from VUWSA's Education Officer, depicted in Figure 7, which called on students to make their concerns known. VUWSA President Lindy Cassidy lamented in 1978 that "the University has changed dramatically over the last five years. All extracurricular activity, be it cultural, sporting, political, or social has steadily declined. Though heavy workloads and continual assessment are not the only reasons, they do share a large part of the blame". ${ }^{132}$ With increased unemployment, students studied harder in order to attain good grades and impress employers. Life at university became "even more competitive and insular". ${ }^{133}$

The Government's attitude towards tertiary education policy changed in 1976, which saw reductions in financial support for universities and students. This contributed further to the difficulties students faced in the material conditions of their studies. The landmark Hughes Parry Report of 1959 had given the government the mandate to better fund universities. The report presented an expansive nationalist vision for universities. Each would be independent, but all would contribute to the development of the nation's economy, culture, arts, and sense of national cohesion. In doing so, gaining a university education would "achieve a nationalist agenda, to instil in students a sense of locality and identity. ${ }^{134}$ The Government had embraced its recommendations. The preponderance of part-time students had long been perceived to be inhibiting the development of New Zealand's universities, so the bursary system was introduced to incentivise full-time

\footnotetext{
${ }^{129}$ David Murray, interviewing Lisa Sacksen, 'NZUSA: Leaders and the led', Salient, Vol. 40, No. 23, 12 September 1977, pp.2-3.

${ }^{130}$ Simon Wilson, 'Editorial', Salient, Vol. 41, No. 6, 3 April 1978, p.2.

${ }^{131}$ Bruce Robinson, 'Editorial', Salient, Vol. 38, No. 14, 20 June 1975, p.2.

132 Lindy Cassidy, 'President', Salient, Vol. 41, No. 25, 25 September 1978, p.15.

133 Cybèle Locke, "Organising the Unemployed: The Politics of Gender, Culture and Class in the 1980s and 1990s," in On the Left: Essays on Socialism in New Zealand, ed. Pat Maloney and Kerry Taylor (Dunedin: Otago University Press, 2002), p.152; Lindy Cassidy, 'President', Salient. Vol. 41, No. 21, 28 August 1978, p.19.

134 Michael Belgrave, From Empire's Servant to Global Citizen: A History of Massey University (Auckland: Massey University Press, 2016), pp.198-201.
} 


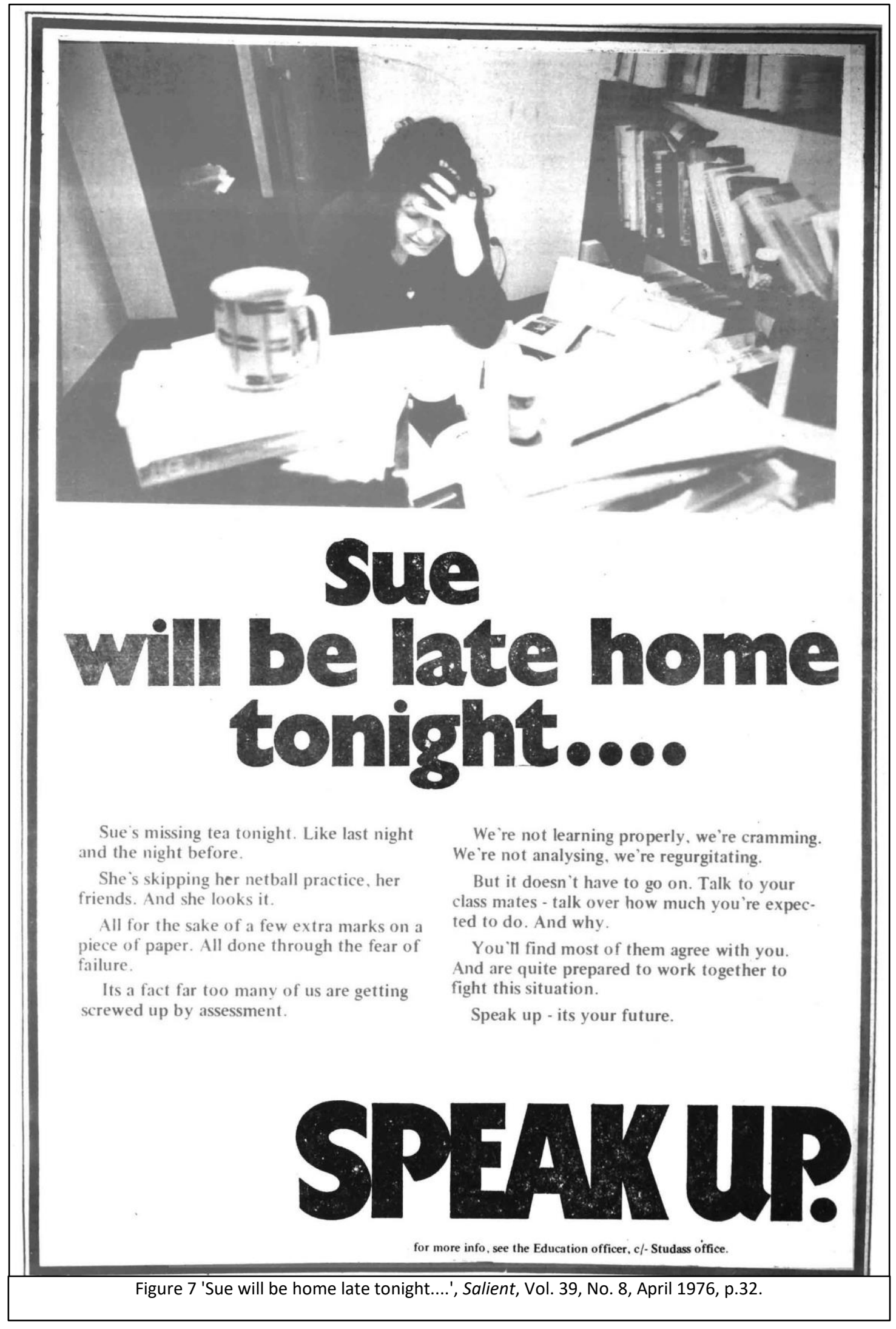


study. ${ }^{135}$ The result was a policy of more open access to universities due to greater funding, which saw a massive increase in the number of university students generally. In 1956, the total roll for the colleges of the University of New Zealand sat at just over 10,000. This number had almost doubled by 1965 and had quadrupled by $1980 .{ }^{136}$ At VUW specifically, the roll soared from 3294 students in 1960 to 7158 in $1980 .{ }^{137}$

The report also led to the establishment of the University Grants Committee to replace the University of New Zealand as the intermediary body which negotiated with universities, Treasury, and the Government to grant university funding. Since the University Grants Committee's (UGC) inception, it had faced few problems securing government quinquennial funding required to maintain functioning universities. The UGC negotiated on the basis of mutually respected heuristics such as target staff-to-student ratios and projected student numbers. This consensus was compromised during the 1975-1979 quinquennium when in an unprecedented move, National attempted to rescind funding which had already been approved, to the tune of $\$ 6$ million. The UGC negotiated to prevent this, but in its place the Government rescinded \$3 million which had been granted in 1977 to cover unforeseen costs. ${ }^{138}$ In negotiations over projected staff numbers for the 1980-1984 quinquennium, National's offer came in well under what the UGC projected would be necessary. ${ }^{139}$ Summarising the period, historian John Gould writes that the 1975-1979 quinquennium "provided, though as yet on a small scale ... disturbing evidence that in determining university funding the role of reasoned argument and even of negotiation might be declining in favour of arbitrary political decision". ${ }^{140}$

These cuts to UGC funding signalled the Government's intentions of cutting tertiary funding at the level of university administration and staffing. Of more immediate concern to students was the value of the bursary. Although the vision of the Hughes Parry Report was still broadly intact in 1972, the value of the bursary of was not deemed satisfactory. The Labour government had stalled on the introduction of the Standard Tertiary Bursary (STB), an improvement to the bursary which they had promised students in the 1972 election. It was only

\footnotetext{
135 John Gould, The University Grants Committee, 1961-1986: A History (Auckland: Auckland University Press, 1988), pp.138-43.

136 Gould, p.21.

${ }^{137}$ Barrowman, Victoria University of Wellington 1899-1999: A History, p.382.

138 Gould, The University Grants Committee, 1961-1986: A History, p.89.

${ }^{139}$ Gould, p.93.

140 Gould, p.91.
} 
after student pressure during an election year that Labour finally introduced the STB in $1975 .{ }^{141}$ However, Muldoon quickly demonstrated that support for students was under threat. During the election, National promised that if elected, they would not introduce an unpopular policy pertaining to the level of support for student teachers, which student politicians took as an attack on student support generally, only to almost immediately backtrack once in power. ${ }^{142}$ This decision and a significant delay in making the first bursary payments in 1976 signalled to Ryall that students would need to take direct action to ensure the hard-won STB was maintained. ${ }^{143}$ More broadly, in an effort to reduce the budget deficit, the Government withdrew funding which had been slated for research and scholarships. ${ }^{144}$ Salient rejected this politics of austerity, noting that one of the "main myths created by the present government is the idea of knuckling down together and tightening our belts". ${ }^{145}$ This solution to the economic crisis asked students and universities to accept worse conditions of study and less financial support.

The inadequacy of the bursary became a significant area of reporting for Salient. Practicing vox pop reporting in 1977, Salient asked several random students whether their bursary was sufficient to live on and whether they would be willing to wait until 1978 for an increase. The answer to both was a resounding "no". ${ }^{146}$ Since March 1976, the bursary had remained at "a constant low", and its value was defined by parameters which students found frustratingly

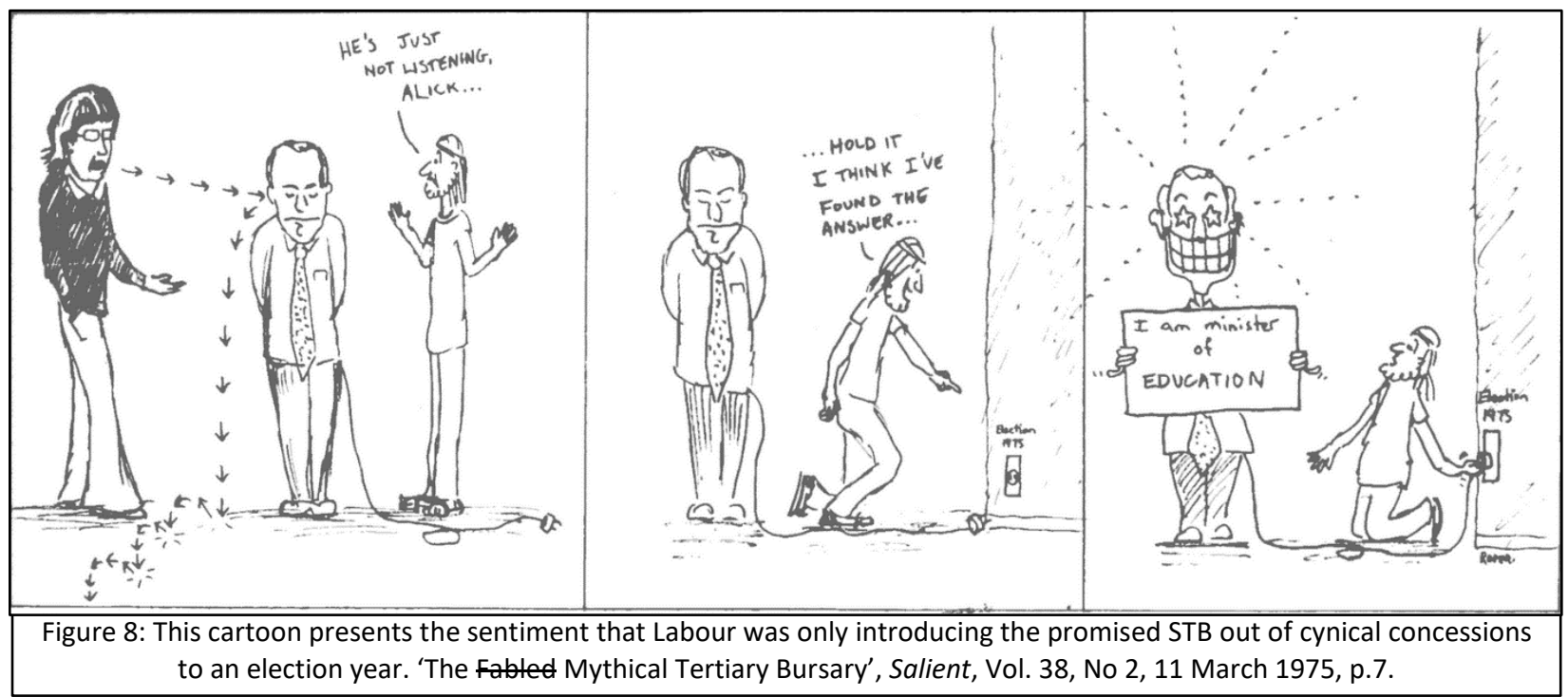

141 'The Fabled Mythical Tertiary Bursary', Salient, Vol. 38, No 2, 11 March 1975, p.7.

142 Peter Franks, 'We've Been Robbed (Again!)', Salient, Vol. 39, No. 8, April 1976, p.3.

143 John Ryall, 'Editorial', Salient, Vol. 39, No. 14, 5 July 1976, p.4.

144 Gould, The University Grants Committee, 1961-1986: A History, p.87.

145 Lindy Cassidy, 'Educ Cuts Continue”, Salient, Vol. 39, No. 16, 12 July 1976, p.2.

146 'Student Say; Too Long to Wait for Too Little Money', Salient, Vol. 40, No. 7, 13 April 1977, p.1. 
arbitrary. ${ }^{147}$ The value of the bursary decreased in real terms each year as inflation reduced the value of the dollar, while the bursary was increased by only nominal amounts which were not in line with inflation. In 1981, Salient assessed that the bursary of \$24 per week was worth "less than half the real value of the 1976 basic rate". ${ }^{148}$ The result was greater pressures on students, both in their studies and their finances, which meant they had less time available to engage in politics and protest action. In Salient, this meant action on the politics of education became less about improving the university and more about fighting against cuts to funding and bursaries.

The solution to flagging student activism and inadequate funding for universities was a coordinated campaign, combatively named "Education Fightback". The campaign was launched in 1979 with Simon Wilson as its coordinator. It was not without precedent. There had been protest action on bursary levels since 1976. ${ }^{149}$ However, Education Fightback addressed what was by 1979 a wide array of issues in tertiary education - inadequate bursaries, restrictions placed on courses, funding cuts to student services, and the loss of academic staff. ${ }^{150}$ It was also meant to have a national approach, with NZUSA President Chris Gosling travelling to each campus to explain the campaign's importance and stoke student support. ${ }^{151}$ A funding drive sold buttons and stickers, and students were called upon to volunteers to distribute leaflets and pamphlets. ${ }^{152}$ The culmination of the campaign was a coordinated march in each university city on 26 July, which drew an estimated nationwide crowd of 11,900, of which 3000 were in Wellington. ${ }^{153}$ In terms of preventing university cuts, it was a moderate success. In his post-mortem of the march in July, Simon Wilson assessed that the UGC's announcement of quinquennial funding later in 1979 "will be bad news. But rest assured that it would be a lot worse if Education Fightback had not gone ahead". He also thanked Beach and Salient for "allowing the campaign to make such good use" of the paper. ${ }^{154}$ Salient had formed an important avenue of organisation, printing supplements and ads in support of the campaign. But as an exercise in revitalising student involvement in activism,

\footnotetext{
147 'It's a Long, Cold Winter', Salient, Vol. 40, No. 15, 4 July 1977, p.3. For example, married students received \$13 a week, while students in a de facto long-term relationship could state they were single and receive \$24 a week instead.

148 Stephen A'Court, 'Editorial', Salient, Vol. 44, No. 16, 20 July 1981, p.12.

149 John Blincoe, 'Action On Bursaries', Salient, Vol. 39, No. 16, 12 July 1976, p.3.

150 'Eight $\$ 64,000$ questions...', Salient, Vol. 42, No. 10, 21 May 1979, p.5.

151 Andrew Beach, 'Education - the fight is on!', Salient, Vol. 42, No. 10, 21 May 1979, p.5.

152 'The Education Fightback Campaign needs you!', Salient, Vol. 42, No. 11, 28 May 1979, p.19.

153 Simon Wilson, 'Wanna buy a button.... please', Salient, Vol. 42, No. 19, 6 August 1979, p.7.

154 Simon Wilson, 'Wanna buy a button.... please', Salient, Vol. 42, No. 19, 6 August 1979, p.7.
} 
both Simon Wilson and Beach agreed it had been a success. Beach wrote that it had been "quite out of the "traditional" mould of VUWSA's past campaigns. Not only has it appeared to have gathered the grudging approval of the student body, but it has succeeded in involving "ordinary, non-political students" to an unprecedented level". ${ }^{155}$

Education Fightback was carried forward in 1980 and Salient continued to act as an important point of organisation for the campaign's activities. Salient's new editor was Stephen A'Court, who had contributed to Salient in the year prior. Like his predecessors, he was a member of the WCL, adopting similar attitudes towards trade unions and viewing issues in class terms. He threw his full support behind Education Fightback early in the year. ${ }^{156}$ The stakes of Education Fightback were higher in 1980, and it proved an eventful campaign. In July, the Government announced it was cutting two thirds of the funding for student welfare services, which became the "hottest issue of the Education Fightback campaign". ${ }^{157}$ Many Salient covers featured images of Minister for Education Merv Wellington. He was the natural enemy of the campaign, particularly because he refused to engage with student politicians after NZUSA leaked Cabinet papers which showed that education funding would be increased in 1981 but reduced in every year following. ${ }^{158}$ Simon Wilson, now in the role of NZUSA President, was singled out and labelled a communist by Muldoon on national television, while Wellington held him solely responsible for the Cabinet papers leak. ${ }^{159}$ Despite this drama and the organisation of two national marches, the campaign was not as successful as it had been in 1979. In Wellington, just 800 turned out for the second march held in July - VUWSA President Philip Sowman wondered if perhaps the issue had been discussed so much that students had become fatigued by it, losing "the enthusiastic backing ... they might have had". 160

Although the Education Fightback campaign was less radical in its demands of university education than the efforts to revolutionise the university in the mid-1970s, Salient's analysis of the campaign was still partly predicated on the class analysis of its editors. Government support for students had enabled more students from working-class backgrounds to afford to attend

\footnotetext{
155 Peter Beach, 'Editorial', Salient, Vol. 42, No. 16, 16 July 1979, p.2.

156 Stephen A'Court, 'Editorial', Salient, Vol. 43, No. 2, 10 March 1980, p.2.

157 Stephen A'Court, 'Editorial', Salient, Vol. 43, No. 7, 7 July 1980, p.2.

158 'Make A Stand!', Salient, Vol. 43, No. 6, 10 March 1980, p.1.

159 Paulette Keating, 'Merv Running Scared', Salient, Vol. 43, No. 10, 5 May 1980, p.1.

160 Philip Sowman, 'President', Salient, Vol. 43, No. 19, 4 August 1980, p.2.
} 
university. ${ }^{161}$ Protecting this principle of open access was crucial to ensuring that people of all class backgrounds could attend university. As Simon Wilson explained, "we now look back on and think 'gosh, how lucky we had it', but at the time, the same arguments [that] these fees will make it harder for lower income people to go to university all applied ... you've gotta make it accessible to a bigger group". ${ }^{162}$ Ryall had recognised this in 1976, warning that if bursaries remained inadequate for the maintenance of living costs while studying, the university could risk becoming only a place for the wealthy. ${ }^{163}$ Students from poorer backgrounds had the most to gain from an improved bursary. Without better support, there were fears they would not be able to afford to continue studying, and new students would be cut off from studying entirely. ${ }^{164}$ While action to improve bursaries had the interests of all students at heart, Salient's analysis was consistent with the socialist views of its editors in its consideration of how the undermining of student support would affect working class students.

\section{Salient's 1981 Tour Reporting}

The 1981 Springbok Tour was a major event for Salient, as it was for the entire country. A'Court remained Salient editor in 1981, and coverage was split almost entirely between two issues -Salient's opposition to the Springbok Tour, and to a lesser degree the Education Fightback campaign for 1981. Throughout the 1970s, Salient had taken a consistent line against apartheid, opposing both the 1973 and 1976 rugby union sporting tours. In 1974, Salient commemorated one year since Norman Kirk cancelled the 1973 tour. It stressed continued vigilance, noting that the oppression of Black South Africans had only gotten worse and that New Zealand had competed in South Africa in a number of sporting codes. ${ }^{165}$ The 1976 eleventh issue was almost not completed on time due to Salient staff involvement with HART protests. The issue noted jocularly that Salient was not a HART front but rather "HART is a Salient front. As is the Executive, the Bookshop, and NZUSA ... Won't you come join us?". ${ }^{166}$ Salient also reported on the general oppressive conditions of South Africa under apartheid, independent of its relevance for New Zealand sport. For instance, it frequently observed the anniversaries of the Sharpeville Massacre on 21 March

\footnotetext{
161 Boraman, “A Middle-Class Diversion from Working-Class Struggle?," p.219.

162 Simon Wilson, interviewed by Max Nichol, 8 December 2018.d

163 John Ryall, 'Ryall Raves', Salient, Vol. 39, No. 6, 5 April 1976, p.2.

164 James Morgan, 'Even that which we had...', Salient, Vol. 41, No. 13, 6 June 1978, p.2.

165 'One Year After', Salient, Vol. 37, No. 7, 17 April 1974, p.5.

166 'Salient Notes', Salient, Vol 39, No 11, 31 May 1976, p.2.
} 
1960 and the Soweto Massacre on 16 June 1976, both cases in which black South Africans had been killed by agents of the apartheid regime. ${ }^{167}$ Salient's opposition to the 1981 Springbok Tour was a continuation of the stance it held throughout the 1970s.

But it was the 1981 Springbok Tour which proved to be the most controversial and divisive moment of opposition to sporting contact with South Africa. In 1981, the stakes were higher than previous tours. Pressure was mounting from black activists in South Africa in the years preceding 1981. So too was the repression of black South Africans on the part of the South African Government, including a number of high profile, violent atrocities in the years preceding $1981 .{ }^{168}$ Meanwhile, New Zealand had signed the Gleneagles Agreement in 1977, an agreement amongst the countries of the Commonwealth which acknowledged that signatories should take "every practical step" to discourage sporting contact with South Africa. ${ }^{169}$ While Muldoon made mealymouthed concessions to this principle, he was clear on the point that "sporting decisions would be made by sportsmen and not the government". ${ }^{170}$ As well as openly contravening the Gleneagles Agreement, Muldoon was openly slandering HART's leaders, such as Trevor Richards. ${ }^{171}$ These conditions meant that international solidarity with the black South African resistance and opposition to Muldoon was more important than ever. Salient rose to the challenge, acting as an explicitly anti-tour organ throughout 1981.

Salient's coverage of the 1981 Springbok Tour served several different purposes. To be an effective focal point of opposition to the tour required students to firstly understand the gravity of the issue, secondly to gain an appreciation of how and when they could take action in Wellington, and thirdly to provide coverage of what was occurring elsewhere in the country as the tour progressed. Towards the first of these aims, Salient published articles ahead of the arrival of the Springboks which explained how the apartheid system enacted violence against black South Africans. One article provided a list of the services and rights black South Africans were being denied, explaining that apartheid was "not simply prejudices and informal attitudes (which occur in most countries) ... South Africa is the only country in the world where racism is enshrined in

\footnotetext{
167 See for example 'March 21 Sharpeville Day', Salient, Vol. 37, No.3, 20 March 1974, p.1; Dave Stott, 'Editorial', Salient, Vol. 40, No. 3, 14 March 1977, p.4.

168 Richards, Dancing on Our Bones, pp.186-7.

169 Richards, p.255.

170 Richards, p.188.

${ }^{171}$ Richards, pp.191-3.
} 
the statutes". ${ }^{172}$ This pre-tour coverage was intended to stoke support for calling off the tour altogether. Salient encouraged students to attend marches on 1 May and 3 July which were intended to deliver a "knock-out punch" to the tour. ${ }^{173}$ It also sought to disabuse readers of the idea that anything positive might be gained from the tour. Henry Isaacs, a black South African student and former recipient of NZUSA's South African scholarship who had studied at VUW in the 1970s, explained to 400 students that "South Africa is a violent society - a country based on structural violence and the removal of black communities to be dumped like garbage on barren wasteland". He strongly encouraged students to heed the call of South African activists to oppose the 1981 tour, dispelling the myth that "rucking in the mud or having a chat over a glass of beer is going to change conditions in the Bantustans". ${ }^{174}$ This reporting informed students of the stakes of the tour, emphasising that the best possible outcome was for the tour to be cancelled entirely.

Once it became clear the tour was going ahead, Salient shifted its coverage to informing students when, where, and how to turn out for anti-tour protests and demonstrations intended to disrupt the tour as best as possible. Salient informed protesters of their legal rights in the event they were arrested at a demonstration and advertised a series of protests in July and August. ${ }^{175}$ These included a rally at the Cenotaph on the day of the game in Hamilton on 25 July, a rally at Parliament on 29 July for the Palmerston North Game, and back-to-back demonstrations at the National Party Conference at the Wellington Town Hall on 31 July and 1 August. ${ }^{176}$ Salient also kept protestors in Wellington informed of what their counter-parts were doing around the country. Reporter Michele A'Court flew to Gisborne for the first game. Her report detailed the tactics employed by protestors, the physical confrontations between police and protesters, and a speech from Donna Awatere on the "oppression of Maoris in the Poverty Bay District and of the ill treatment of Maori soldiers by white South Africans during the war'. A'Court herself was the subject of scrutiny. Though she was there as a member of the press, the police quickly established

\footnotetext{
${ }^{172}$ Christopher Sheppard, 'The art of the impossible: South African Reforms a Sham', Salient, Vol. 44, No. 8, 27 April 1981, p.2.

173 David Murray, 'Why We are Marching on May 1', Salient. Vol. 44, No. 8, 27 April 1981, p.3. Salient estimated these marches attracted 75,000 and 100,000 people across the country respectively. See Stephen A'Court, 'Editorial: July 3 a Massive Success', Salient, Vol. 44, No. 14, 6 July 1981, p.13.

174 David Murray, 'A violently racist society', Salient, Vol. 44, No. 4, 23 March 1981, p.6.

175 Shelley Robertson, 'Read This! Demonstrations and The Law', Vol. 44, No. 16, 20 July 1981, p.9. To aid arrested protesters, SRC passed a motion to set aside $\$ 1000$ of association money to "assist people with bail, legal aid and excessive fines".

176 'Anti-Tour Activities', Salient, Vol. 44, No. 16, 20 July 1981, p.9.
} 
that she was associated with protesters. They hassled her over the validity of her Press Card and tried to push her to stand with protesters instead of the rest of the press corps during the pre-kickoff protests. ${ }^{177}$ While Salient was not the only publication providing this kind of information, it was a dedicated avenue through which protestors could gain practical information about protest action and the intended tactics used.

Many students would have perceived the coverage in Salient to be a more accurate account of the conduct of police and protestors than was available in the mainstream press. The violence that police perpetrated against protesters was reported with sympathy for the protesters, in contrast to the angle of the mainstream press which cast the protesters as the instigators. ${ }^{178}$ This differentiation from the mainstream media was central to Stephen A'Court's intention for Salient's coverage of the tour. He had sought to chronicle a "record of the events of ' 81 in a way that the downtown papers never would. He succeeded magnificently in that". ${ }^{179}$ Of course, some students felt that Salient had no business taking such a clear partisan stance. Minister of Justice Jim McLay also put the boot in, threatening the paper with legal action over the Salient's coverage of the tour. Stephen A'Court was unapologetic, explaining that while Salient's "policy of considering for publication material from all viewpoints still stands, the paper as a whole will continue its attitude to the tour ... That Salient takes a stand on the tour is, I believe, a correct decision". 180

Salient's close involvement in the anti-tour movement of 1981 is made clear in a history of the Wellington anti-tour activity by Citizens Opposed to the Springbok Tour (COST). It was co-edited by former editor Peter Beach, with assistance from Salient's technical editor for 1981, Fergus Barrowman, and contributions by 1980 staffer Ganesh Nana. Both Stephen and Michele A'Court provided photos, as did former editor Bruce Robinson, A'Court's successor as editor Mark Wilson, and former VUWSA President and Salient technical editor Gyles Beckford. The history itself was even printed by Salient's printer, Wanganui Newspapers. ${ }^{181}$ Photos of Simon Wilson were also featured, and he was a member of the "Second XV", the list of "subversives and

\footnotetext{
177 Michele A'Court, 'Boks kick off', Salient, Vol. 44, No. 17, 27 July 1981, p.9.

${ }^{178}$ Campbell Duignan, 'Blood on the batons: The role of the State forces', Salient, Vol. 44, No. 18, 3 August 1981, p.1.

179 Richard Adams, 'Editorial', Salient, Vol. 49, No. 13, 7 July 1986, p.2.

180 Stephen A'Court, 'Editorial: The Real Issues', Salient, Vol. 44, No. 18, 3 August 1981, p.11. Exactly which content McLay took issue to is not specified, but it may have been over alleged instances of police violence which were reported in issue seventeen.

${ }^{181}$ Geoff Walker and Peter Beach, eds., 56 Days: A History of the Anti-Tour Movement in Wellington (Whanganui: Citizens Opposed to the Springbok Tour, 1982), p.1.
} 
radicals" Muldoon released to in an attempt to undermine the anti-tour movement and signal to those on this list that the SIS was keeping tabs on them. ${ }^{182}$ David Murray was the President of the VUW Anti-Apartheid Club. ${ }^{183}$ The involvement of Salient staffers past, present, and future, in the production of the COST history, and the anti-tour movement more generally, serves to neatly demonstrate the paper's activist roots in the 1970s. The 1981 anti-tour movement was a particularly strong articulation of the fact that Salient's reporting was an extension of its contributors' political activism in Wellington.

\section{Conclusion}

Salient's content and style of journalism in the long 1970s was an expression and an extension of the broad-based, multi-issue political activism which occurred during this time. Salient's editors and contributors were closely involved in this activism. They used Salient as a platform to spread these ideas. The highpoint of this kind of reporting was during the 1981 Springbok Tour, when Salient became an anti-tour publication, with contributors helping organise protest events as well as providing accounts of those events. Salient was an alternative to the more conservative mainstream media. This was the clearest and most high-profile example of Salient's activist reporting, but it was a characteristic that was consistent throughout the 1970s. Many of the issues Salient reported on were cast in class-terms, reflecting the influence of MILO within the Salient office and the VUWSA Executive. The close connection between MILO and trade unions manifested in Salient support for militant trade unionism and workers' rights, particularly as students and workers both began to feel the effects of an openly anti-union Prime Minister, cuts to education funding, and rising unemployment. Though Salient had this socialist, pro-union line in the 1970s, the particular decisions and interests of individual editors did have an effect on the content of the paper. Roger Steele's advocacy for te reo Māori in Salient was ahead of its time for a publication which was not specifically Māori-focused, and John Ryall attempted and succeeded (at least in the year he was editor) in putting aside Salient's animosity towards the Trotskyist Young Socialists. It would be overstating the case to suggest that Salient's socialist direction in the 1970s reflected broad-based support for socialism on campus. Rather, the newspaper's editors deployed the platform they had in Salient to advance the interests of MILO and attempt to boost

\footnotetext{
182 Simon Wilson, interviewed by Max Nichol, 8 December 2018; Walker and Beach, p.95.

183 Paulette Keating, 'No excuse for excuses', Salient, Vol. 44, No. 4, 23. 3 March 1981, p.6.
} 
support for the issues the organisation was concerned with, particularly militant, working-class trade unionism. This occurred alongside the paper's other functions of providing campus news and entertainment. There is no compelling evidence to suggest that Salient intended to be a primarily theoretical or intellectual journal; rather it took a primarily activist role as many alternative publications did in the way Toby Boraman describes. However, individual contributors, particularly those associated with MILO in the mid-1970s such as Terry Auld, did discuss the nature of communist theory and its application in New Zealand and around the world. Bruce Robinson, who edited Salient in 1975, also demonstrated concern with the level of foreign control over New Zealand, which shared some similarities with Bruce Jesson's development of nationalistsocialism. 


\section{Chapter Three}

\section{Changing Contexts, New Challenges: Salient's Response to Neoliberal Education Reform, 1982-1989}

Salient's involvement in the anti-Springbok Tour movement marked the high-point of its close involvement in political activism, which had been a consistent feature of its coverage in the 1970s. In the 1980s, Salient began to shift away from this style of journalism, assuming more of a role as political commentator and advocate for student interests. Socialism and advocacy for trade unionism as central political pillars for the paper became less prominent as the influence of the Workers' Communist League (WCL) over the Victoria University of Wellington Students' Assocation (VUWSA) and Salient loosened. While early and mid-1980s editors such as Mark Cubey, Sally Zwartz, and Jane Hurley held generally left-wing and indeed even socialist views, they did not subscribe to a particular brand of doctrinaire socialism. VUWSA on the other hand moved further to the right, with a series of more conservative Executives in the early 1980s, compromising the loose political consensus between VUWSA and Salient which had existed in the 1970s. Formal ties between student politics at VUW and the WCL and Wellington trade unions weakened as a result. This shift was gradual - Margie Thomson, who was a steady Salient contributor, a member of the WCL, and on the VUWSA Executive demonstrates as much. However, in the main, Salient came to be informed by a range of political perspectives held by its editors, who responded to new and emerging social and political forces.

This chapter examines how Salient responded to and was shaped by new contexts. Demands for Māori sovereignty and greater appreciation of racism in New Zealand followed from a schism between Māori activists and the Pākehā left who had been active during the anti-tour movement. Whereas VUWSA responded to these ideas with rejection and dismissal, Salient's response was more ambiguous. At times the paper showed an ostensibly sensitive understanding of Māori nationalists while at other times it published material which critiqued or dismissed the ideas of Māori self-determination articulated by activists such as Ripeka Evans and Donna Awatere. Radical ideas and lukewarm responses to them sat side-by-side in Salient. In 1984, Sally Zwartz was Salient's first woman editor since 1941, and she was followed by Jane Hurley in 1985. Salient gave more prominence the gay and lesbian rights movement, supporting the Homosexual Law Reform Bill of 1985 and consistently publishing gay and lesbians voices in a column from 1983. The election of a Labour Government in 1984 brought some optimism that support for 
tertiary education and students would dramatically increase. This optimism dissipated in the face of a new, more fundamental assault on the principles of open access and heavy subsidisation of universities. The notion that some kind of user pays system be implemented gained currency with both Labour and National. This had profound implications for the very values which underpinned tertiary education. Consistent with the general neoliberal ideology which underpinned the reforms of the 1980s, the idea that education provided a public benefit through a more highly educated population gave way to the idea that it was a private good which enabled students better access to highly paid and respected job titles. Taken as read, this justified placing more of the financial burden upon the individual student. Salient followed these developments closely. The issue of education funding dominated the pages of the paper in the latter half of the 1980s even more than it had in the late 1970s, particularly in 1988 and 1989 when both the Labour Government and universities themselves began to move more rapidly towards user pays policies. VUWSA's response was to focus in on opposing cuts to education. In the second half of the 1980s, while it was not necessarily right-wing, it was pragmatic and focused on representing student interests instead of its former role of championing the political positions of its students through the debate and creation of policy at Student Representative Council. Major reforms passed in 1988 formalised this new direction in the structure of VUWSA. Salient had already begun to head in this direction on its own. The gravity of the threat user-pays posed to students prompted Salient to dedicate more of its coverage to education. The paper took an anti-user pays stance, and was used as a platform for opposing, reporting, and responding to developments in education policy. Other political issues, though present, were edged out as a result. Salient continued to push a progressive viewpoint, covering a variety of social and political issues, but these issues came to be dwarfed by the issue of educational reform.

\section{Declining Influence of the WCL}

Following the 1981 Springbok Tour, the WCL maintained some influence within student politics at VUW. The old divisions between Trotskyists and Maoists remained. ${ }^{1}$ As ever, this influence was funnelled through a small but committed group of WCL members in Salient and on the VUWSA Executive. Margie Thomson contributed to both. For Thomson, the anti-Springbok

\footnotetext{
${ }^{1}$ Mark Cubey, interviewed by Max Nichol, 5 December 2018.
} 
Tour protests had been massively energising event, demonstrating the potential for mass action. Thomson had come from a relatively conservative family in Wellington. Her high school education began at Queen Margaret's College, a prestigious Wellington private school, paid for out of an inheritance from Thomson's grandmother. In her final year of high school, to her parents' chagrin she moved to Onslow College, which still held a reputation as a hotbed of student political action. She was radicalised at university through her involvement in the anti-Springbok Tour protests she and her brother's opposition to the tour had resulted in being kicked out of their family home by their pro-tour father. Thomson met former Salient editor David Murray while he was selling issues of the WCL newspaper, Unity, on campus, and she became a member of the WCL. ${ }^{2}$ She was placed into the uncontested position of International Officer on the VUWSA Executive in 1982 as a WCL candidate. It was in this capacity she became a regular contributor to Salient, focusing particularly on international politics. She and her fellow WCL members continued the practice of visiting industrial workplaces in an attempt to radicalise workers:

We'd have a roster, we'd drive out [to the Hutt Valley] with our pile of Unity's ... and we'd stand at the gate ... and we'd just try and capture peoples' attention as they went in $\ldots$ at the end of it we'd debrief in the car about how many conversations we'd had, whether we'd sold any newspapers, whether we thought there might be a possible contact inside. ${ }^{3}$

Through the WCL, she was also involved in a wide variety of other protest actions, including nuclear disarmament and free Palestine. She became the Salient commercial typesetter in 1983, which enabled her to "keep hanging around and keep being political". 4

Continuing its line from the late 1970s, in 1982 Salient advocated students support unions and not scab while working over summer. Indeed, a collaboration between the Clerical Workers' Union and VUWSA set a positive example to students that supporting unions was in their best interests. The Student Community Service Programme, a programme jointly run by the government and universities to find students work over summer, owed backpay to a significant number of students due to poor administration. The Clerical Workers' Union worked closely with

\footnotetext{
2 Similarly, Leonie Morris, regular contributor to Salient in the 1970s, was one of two women who recruited Sue Bradford to the WCL following the 1981 Springbok Tour. See Chamberlain, Constant Radical: The Life and Times of Sue Bradford, p.161.

${ }^{3}$ Margie Thomson, interviewed by Max Nichol, 9 December 2018.

${ }^{4}$ Margie Thomson, interviewed by Max Nichol, 9 December 2018.
} 
VUWSA to gain proper compensation for the affected students. ${ }^{5}$ However, this was the tail-end of WCL influence on student politics and Salient. The WCL was in decline throughout the 1980s. This was not due to any particularly significant schism in the organisation but simply the result of a loss of momentum, culminating in its final meeting in early $1990 .^{6}$

Stephen A'Court was the last Salient editor to have direct involvement in the WCL. Salient's editor for 1982 was Mark Wilson. In terms of setting an editorial agenda, he took a light touch, perhaps influenced by his experience working as a journalist in the mainstream media. He wrote far fewer editorials than any other editor, leaving less of a personal political stamp on Salient as a result. The editor for 1983, Mark Cubey, was not a member of WCL, but was a fellow traveller. His vision for Salient was that it be political and provocative, but also fun and provide some levity to the political situation on campus. Though his politics were broadly left-wing, he did not see himself as "part of any faction". 7 Similar to Mark Wilson, Zwartz did not see value in a strong editorial presence. She drew criticism from a student for neglecting to write an editorial for two weeks in a row, leading her to wonder, "What does he want? I assume, a strong editorial personality on whom to focus his appreciation or - infinitely more likely - displeasure with Salient. I can see his point. But it's an essentially limited attitude to take. And, what's more, essentially male in the expectation it suggests of an aggressive, obtrusive leadership figure. There's an editorial presence [in] Salient with or without editorials, for those astute enough to spot it". ${ }^{8}$ Hurley, in 1985, did consider herself a socialist but did not align herself with a particular doctrine of socialism. Rather, she drew her socialist politics from her parents' left-wing views, her Catholicism, and the leftwing politics she was exposed to while studying English and French at university. ${ }^{9}$ By the time of her editorship in 1985, the influence of the WCL within the Association was a "rumour and a legend ... we were all committed left-wing, or most of us that I remember, but ... by the time I was editor they'd all graduated!" 10 Simon Johnson, VUWSA President in 1986, concurred that in

\footnotetext{
5 Paul Cochrane, 'President', Salient. Vol. 45, No. 3, 15 March 1982, p.2; Roger Tobin, 'Unions and you', Salient, Vol. 45, No. 7, 19 April 1984, p.6.

${ }^{6}$ Smith, Working Class Son, p.164; Chamberlain, Constant Radical: The Life and Times of Sue Bradford, p.206. Growing scepticism about the actions of foreign communist states also had some effect. Simon Wilson became disillusioned as the atrocities committed by the Khmer Rouge in Cambodia came to light. He left the WCL in 1982.

${ }^{7}$ Mark Cubey, interviewed by Max Nichol, 5 December 2018.

${ }^{8}$ Sally Zwartz, 'editorial', Salient, Vol. 47, No. 5, 26 March 1984, p.2.

${ }^{9}$ Hurley's "viscerally left wing" mother grew up in a working-class family in the English Midlands. It was from her mother that Hurley gained much of her appreciation for the struggle of the working-class. Her father came from a National-voting farming family, but Hurley described his politics as "centre left".

10 Jane Hurley, interviewed by Max Nichol, 9 February 2019.
} 
the "late 70 s and early $80 \mathrm{~s}$, most of the student activists were members of the Workers Communist league [sic]. They had a high ideological commitment to what they were doing. When they left in the mid 80s, some direction was lost". ${ }^{11}$ Links from Salient to trade unions did remain, but this was less on the basis of coordinated institutional collaboration between the WCL and particular unions and union officials. Instead, more informal personal connections existed between Hurley, her staff, and unionists, which were looser than the relationship between Salient editors and union officials which had existed in the 1970s. ${ }^{12}$

The withdrawal of socialist politics from Salient was well-demonstrated in 1987. Salient published a feature which explained the benefits of joining a union during summer employment and the unions they were most likely to encounter. This echoed articles which had been commonplace in the late 1970s and early 1980s. However, the article differed significantly to earlier articles on the point of scabbing. Its author came away somewhat "disillusioned" about unions after a discussion with an official from the Hotel Workers' Union who had raised the common issue of students scabbing and being reluctant to engage in industrial action. The author felt that for students, the loss of a week's wages over summer could mean the difference between making it through the academic year or not. She was understanding of students providing scab labour, arriving at the conclusion that unions "should be there to help and support, not criticise their members' aims and wishes". ${ }^{13}$ This position would have been anathema to Salient's editors in the 1970s, who were adamant that students should support collective industrial action even if it was likely to cause personal financial difficulty. This divergence from basic tenets of trade unionism and the politics of solidarity signals a noteworthy shift in the enduring political line of Salient. There was still support for socialism and trade unionism in Salient in the 1980s. ${ }^{14}$ However, by the mid-1980s this had ceased to be a fundamental principle underpinning the political direction of the paper.

\footnotetext{
${ }^{11}$ Simon Johnson, 'Salient steps into its time machine and sets the dial for 1986 and 1987', Salient, Vol. 52, No. 24, 25 September 1989, p.6.

12 Simon Wilson, interviewed by Max Nichol, 8 December 2018.

${ }^{13}$ Alison Hart, 'Power in a Union', Salient, Vol. 50, No. 6, 13 April 1987, pp.10-11.

${ }^{14}$ This expression could also be seen, for example, in Salient's criticism towards NZUSA re-negotiating their collective agreement with its office staff in 1987. The agreement applied to the office staff of NZUSA's constituent student associations. NZUSA was proposing cutting some sick days and utility leave, in return for a negligible $0.8 \%$ bump in pay. See Paul Wiggins, 'NZUSA Sells Up... \& Stuffs its Workers', Salient, Vol. 50, No, 6, 13 April 1987, p.5.
} 
The decline of the influence of the WCL in Salient was mirrored in VUWSA. ${ }^{15}$ Not only did the WCL presence in VUWSA recede, but it was partly replaced by a nascent right-wing and conservative pushback. The result was a more adversarial relationship between Salient and VUWSA in the mid-1980s. In the 1970s, the relationship between Salient and VUWSA was close. As the VUWSA Executive was democratically selected, MILO/WCL were not able to guarantee control over the Association, but from year to year many Executive positions were filled by members of the organisation. ${ }^{16}$ Through this connection, many of the individuals involved in Salient and VUWSA held the same or similar politics. A significant exception was VUWSA President Andrew Tees, who beat out Salient editor Simon Wilson in 1979. Tees was decidedly right-wing and regarded as antagonistic in his capacity as VUWSA President. ${ }^{17}$ His election was perceived as a setback for left-wing activism on campus and his presidency was marked by conflict with Salient. ${ }^{18}$ He was pushed out by a vote of no confidence in 1979 and replaced by an interim president. ${ }^{19}$ Barring Tees, in the late 1970 s and early 1980 s there had been a fairly strong consensus between VUWSA and Salient, mediated by the WCL.

This consensus was compromised in the early 1980s with a succession of more "moderate", if not right-wing executive members who butted heads with Salient. In 1982, a group of students stood as a ticket, billing themselves as "the Moderates" with the express intention of making VUWSA less radical, less political, and more focused on education. They also wanted to make Salient and Radio Active more "balanced". On the issue of education, the Moderates felt that campaigns such as Education Fightback involved too much "“rampaging” and not enough contacts made in Parliament". They believed the protest action on education cuts organised by VUWSA harmed students' credibility and instead promised a "more moderate, pragmatic approach" to negotiation than previous Executives' "radical approach". Their candidate for Media Officer Bruce Hill, standing unopposed, pledged that he would "never order anyone to do anything" but did believe that "Salient's fairly free at the moment. Some people say it's one-eyed. I think it has been". ${ }^{20}$ According to the Moderates' de facto leader, Presidential candidate Leighton Duley, they

\footnotetext{
${ }^{15}$ Mark Cubey, interviewed by Max Nichol, 5 December 2018.

${ }^{16}$ Simon Wilson, interviewed by Max Nichol, 8 December 2018.

17 In 1983, Tees was a part of Bob Jones' short-lived libertarian party, the New Zealand Party. See Andrew Tees, 'New Secretary Defends NZ Party', Salient, Vol. 46, No. 21, 12 September 1983, p.11.

${ }^{18}$ Simon Wilson, interviewed by Max Nichol, 8 December 2018.

${ }^{19}$ Peter Beach, 'Editorial: Promise of things to come', Salient, Vol. 42, No.11, 28 May 1979, p.2.

20 'Moderates stand', Salient, Vol. 45, No. 23, 20 September 1982, pp.1, 4.
} 
adhered to no particular political ideology or party. Rather, the Moderates defined themselves in opposition to established student politics. They cast themselves as the reasonable option with an interest in student welfare, as against the radicals pushing a political agenda through VUWSA and Salient.

The Moderates were successful in their bid to takeover VUWSA. Mark Wilson was concerned at what their election might signal, writing that "things bode ill for 1983 ... Student politics, like politics the world over are cyclical - swinging from right to left with the motion of time's pendulum - and perhaps the elections results were a hiccup". ${ }^{21}$ In a letter to Salient in early 1983, Hill made the Moderates' anti-radical stance even clearer. He explained that they were a politically disparate group: “Leighton Duley is regarded as being right wing, perhaps that's true. Heather Shotter has been very much involved in the National Party ginger group, the Young Nationals ... Tanya Phillips is basically non-political. Jon Roscoe is more inclined to the centre, I myself have been involved in liberal causes whenever my position as a journalist permitted". ${ }^{22}$ The thing that bound them together was the shared opposition to "the actions of the Workers Communist League in the five or six years before now. Youthful idealism degenerated into a highhandedness and a lack of tolerance for the views of others". They levelled that the WCL-controlled VUWSA, supported by "a bias within the staff of Salient”, had alienated less radical students from their Association with a focus on international politics and "extreme" left-wing positions. ${ }^{23}$ Since the 1970s there had always been students who believed that VUWSA, NZUSA, and the establishment student media had no business concerning themselves with political issues which had no direct bearing on students' lives and livelihoods. The voting in of the Moderates was a stronger articulation of this idea, which suggested a shift in student politics and the emergence of a more conservative tenor for VUWSA. As Hill demonstrates, the grip of the WCL on VUWSA slipped not only due to its own steady decline, but also due to a deliberate campaign from a group which was positioned to the right of the WCL.

In 1983, Salient feuded with the Moderates, particularly at the beginning of the year. Cubey fired the opening shots, noting Duley's pro-Springbok tour stance in 1981 in the first issue: "Supporting the 1981 tour of New Zealand by the representatives of racist apartheid South Africa,

\footnotetext{
${ }^{21}$ Mark Wilson, 'Editorial', Salient, Vol. 45, No. 25, 4 October 1982, p.3.

22 Bruce Hill held a part-time position as a reporter for Radio Windy.

${ }^{23}$ Bruce Hill, 'Who Makes the Moderates?', Salient, Vol. 46, No. 1, 28 February 1983, p.23.
} 
as Leighton Duley does, is not "moderate"". ${ }^{24}$ Duley responded the following week in his Presidential column, saying that it is "now 1983 (so I am told) but there are still people dribbling on about the 1981 tour. I am amazed to read that by supporting the tour (my democratic choice), I am automatically convicted as being a supporter of apartheid - how absurd!". ${ }^{25}$ This set the tone for their relationship as the two used their respective platforms in Salient to take swipes at each other. It should be noted that the personal significance of this tension between Salient and VUWSA was perhaps less serious than it appeared. In early 1984, Zwartz noted that "a lot of energy was expended on this campus on so-called radical versus moderate warfare. Possibly everyone liked each other really - in which case a lot of time was wasted in pretending they didn't". ${ }^{26}$ As Cubey explained, the animosity between himself and Duley was at least partly performative. Certainly, they "had stoushes" and did hold different political views, but they also had "mutual respect" and a relatively stable working relationship as the heads of the two major branches of VUWSA activity. It was fun to "play the person and make fun but ... it's a game, you know? It's a show ... that was good, to have something battle against". ${ }^{27}$

Nevertheless, that the Moderates were voted in did signal a shift in student politics which was carried forward in the ensuing years. At the University of Auckland, the Society of Independent Students established a rival newspaper to the long-standing Craccum, titled Campus News. While their intention was to deliberately set themselves against Craccum, which they believed had "degenerated into mere propaganda during 1983", they distributed the paper at the Massey, Victoria, and Otago campuses as well. The reason for this wide distribution was the belief that all over the country, the "subsidised student newspapers ... are nothing more than an expensive fait accompli of no interest or relevance to those who do the paying ... hypocritically wasting student money hand over fist on unpopular political drivel". ${ }^{28}$ The same year, despite Zwartz's intention to put the disagreements of 1983 behind her, there was still some tension between the Association and its newspaper. VUWSA President Stephen Dawe "fired the first shots" over Salient's decision not to print an issue during the Easter break. ${ }^{29}$

\footnotetext{
${ }^{24}$ Mark Cubey, 'editor', Salient, Vol. 46, No. 1, 26 February 1983, p.2.

${ }^{25}$ Leighton Duley, 'president', Salient, Vol. 46, No. 2, 7 March 1983, p.2.

${ }^{26}$ Sally Zwartz, 'ed', Salient, Vol. 47, No. 1, 27 February 1984, p.2.

${ }^{27}$ Mark Cubey, interviewed by Max Nichol, 5 December 2018.

28 Philip Ross, 'SIS Wave Own Flag', Salient, Vol. 47, No. 17, 30 July 1984, p.17.

${ }^{29}$ Sally Zwartz, 'editorial', Salient, Vol. 47, No. 8, 16 April 1984, p.2.
} 
As editor, Hurley likewise butted heads with a VUWSA Executive which was out of step with Salient's politics. She noticed the nascent conservatism within the student body "through personalities rather than through philosophies. All of a sudden there were people coming in and being elected who weren't left-wing and who didn't have a history of activism or interest in politics". In particular there was "a lot of friction" with President Steph Haworth, who Hurley considered right-wing. ${ }^{30}$ Following an issue with the VUWSA elections for 1986's Executive, which some of the 1985 Executive felt should be declared invalid on a technicality, Hurley admitted "that student politics at Victoria is, at the moment, even fouller than usual". ${ }^{31}$ Salient published a comprehensive takedown of the Executive's performance at the end of the year. It pulled no punches, with the caveat that if "anyone wants to sue us for libel, any similarity between the persons in this article and persons, living or dead, is purely intentional, whoops, coincidental". The thing its authors felt they would remember the most about student politics was "the number of misdeeds, injustices and the vast amount of sheer incompetence you have to ignore to survive". Of Haworth, they wrote that "Steph didn't do much education work ... Steph works hard in a strange way and if she wasn't president she might have been a good thing. But she is pres and all in the Association have suffered". ${ }^{32}$ The following year at the VUWSA Annual General Meeting, Haworth presented a report which accused Salient of refusing certain kinds of content and took issue with the Executive takedown. Hurley, still at Salient as technical editor, defended herself, citing a dodgy typesetter as the reason some content had not been printed, but the report was accepted with these anti-Salient sections. ${ }^{33}$

The general decline of the WCL was mirrored at Salient and in VUWSA. While Thomson was involved in all of these organisations, she was one of the last WCL members to have a significant involvement in student politics at VUW. The socialist analysis and connection to trade unions which had formed an important part of Salient's political direction was much less prominent in the early 1980s. Not only this, but VUWSA became more conservative, marking the end of a loose but relatively consistent consensus between the Association and its paper.

\footnotetext{
30 Jane Hurley, interviewed by Max Nichol, 9 February 2019.

31 Jane Hurley, 'Editorial', Salient, Vol. 48, No. 23, 23 September 1985, p.2.

32 Vidva Dinamani and Ann Frankel, 'Rubbing Salt In...', Salient, Vol. 48, No. 24, 30 September 1985, p.7.

33 Bernard Steeds, 'A.G.M', Salient, Vol. 49, No. 12, 16 June 1986, p.3.
} 


\section{Salient's Women Editors, Gay and Lesbian Rights, and Māori Sovereignty}

The drift away from the WCL's particular brand of doctrinaire leftist politics did not mean that Salient ceased taking political stances or following a broadly left-wing editorial direction. In the early 1980s, it continued to present a progressive viewpoint on a variety of political issues. Salient took a strong pro-Palestine stance, an issue that Thomson wrote about a lot. ${ }^{34}$ She penned a two-part series on Zionism which declared that Israel was a "colonialist settler state", comparing the treatment of Palestinians to South African apartheid. ${ }^{35}$ Mark Wilson made his views on the issue abundantly clear with a two-page, colourised centrefold with the words "Defend the Palestinians" splashed across a burnt out city scape. ${ }^{36}$ Mark Wilson drew some criticism for this decision, to which he responded "tough shit turkeys, the content of Salient is the domain of the editor, no one else ... Take a read of the Constitution, sonny". ${ }^{37}$ Salient also took an anti-nuclear stance, supporting the protests against the entry of the USS Truxtun into Wellington harbour in 1982 and the USS Texas in 1983. ${ }^{38}$

In both its content and its staff, Salient reflected important developments for women in the early 1980s. Historian Barbara Brookes notes that the early 1980s saw "stories of women's 'firsts"” dominate the media as more women entered the areas of the workforce which had long been the exclusive domain of men. However, unequal pay for women remained an issue and wider employment opportunities were mainly available to well-educated women. Unionists such as Sonja Davies raised the profile of working-class women and women's issues within the trade union movement, pushing hard for the adoption of the Working Women's Charter. ${ }^{39}$ Salient profiled Davies in 1984, highlighting that many of her activities "have marked a first for women" and noting the adverse effect the Industrial Law Reform Act was likely to have on working women in particular. ${ }^{40}$ Zwartz was Salient's first woman editor since Shirley Grinlington in 1941, but she was very much the outlier. Zwartz appreciated the significance of her appointment, but noted how long it had taken for another female editor, and speculated that Grinlington perhaps gained her

\footnotetext{
${ }^{34}$ Margie Thomson, interviewed by Max Nichol, 9 December 2018.

${ }^{35}$ Margie Thomson, 'Zionism is Racism', Salient, Vol. 45, No. 7, 19 April 1982, p.12.

36 'Defend the Palestinians', Salient, Vol. 45, No. 22, 13 September 1982, pp.8-9.

${ }^{37}$ Mark Wilson, 'In Reply', Salient, Vol. 45, No. 23, 20 September 1982, p.15.

38 'Truxtun comes, and goes', Salient, Vol. 45, No. 11, 31 May 1982, p.1; Mark Cubey, 'editor', Salient, Vol. 46, No. 20, 15 August 1983, p.2.

${ }^{39}$ Brookes, A History of New Zealand Women, pp.380-4.

${ }^{40}$ Margie Thomson, 'Working for the Workers', Salient, Vol. 47, No. 5, 26 March 1984, pp.8-9.
} 
position due to the dip in the number of male students during World War Two; this at least "helped make her appointment possible". Since then, Zwartz observed that women had come to have a much greater role in student politics: "Women fill five of the six NZUSA elected positions, including that of president. Of the seven student association presidents, four are women. Two of the student papers are edited by women. But the world of student politics remains a statistical aberration". ${ }^{41}$ Zwartz's appointment also reflected the changing gender demographics of VUW students. In 1965, just over a quarter of students were women; by 1985, 46.7\% of students were women, increasing to just over half by $1990 .{ }^{42}$ It was an illustrious year for Salient. Zwartz, with her prior journalistic experience, provided strong editing and feature writing. Cubey as typesetter and general administrator ensured things ran smoothly, while technical editor Tim Bollinger lent the paper a distinctive and creative design. ${ }^{43}$

Zwartz was succeeded by Jane Hurley. Hurley had felt some responsibility to take up the editorship - the idea of being the third woman, and the second in as many years, to edit Salient appealed to her. She felt that women at Salient had been "part of the backbone" of the newspaper, "but probably didn't get the recognition". Being the third woman editor brought its own pressures: "Sally had been such a fantastic editor ... I felt this huge responsibility, that if I wasn't a good editor then I'd have let women down for all time kind of thing". Needless to say, this kind of pressure was not likely to have been felt by the men who edited Salient. Her impression of what Salient could and should do at that time was "anything and everything ... the idea at that time was that student newspapers had a lot of freedom to tackle subjects and things that the mainstream media weren't necessarily doing ... student media was one way in which people who didn't have a voice otherwise or weren't getting heard ... would have a chance to speak up, we could be a platform for them". ${ }^{4}$

During her time as editor, Hurley faced a legal threat from the History Department at the university. She had edited the VUWSA Student Handbook with two co-editors in the summer of 1984 and 1985. The handbook provided course critiques so that students could assess for themselves which courses and programmes of study might appeal to them. As a part of this function, someone had noted that a Professor in the History Department was known for "sexual

\footnotetext{
${ }^{41}$ Sally Zwartz, 'editor', Salient, Vol. 47, No. 2, 5 March 1984, p.2.

42 Barrowman, Victoria University of Wellington 1899-1999: A History, p.382.

43 Jane Hurley, interviewed by Max Nichol, 9 February 2018.

44 Jane Hurley, interviewed by Max Nichol, 9 February 2018.
} 
harassment". The Department threatened a defamation suit against the editors of the handbook, demanding they print a retraction. Hurley did so in the first issue of Salient, admitting that "sexual harassment" suggested a higher level of physical misconduct than had been alleged and clarifying that the "writer of the critique is concerned ... [with] the 'milder' forms of harassment - the unwanted comments, the innuendo, the disparagement of women simply because they are women". ${ }^{45}$ Some good came of the affair. The reporting was at least partly responsible for prompting the university administration to put in place policy on sexual harassment the following year, which was published in Salient. The policy made students aware of who they could speak to if they were subjected to inappropriate comments or sexual harassment.

Unfortunately, Hurley's year as editor was marred by a series of technical and political issues. These hindered the achievement of what she had envisioned for the newspaper. Salient's typesetting machine, which had already displayed a habit of breaking down in 1983, was beset by with mechanical problems in 1985. It regularly broke at crucial moments in the paper's weekly production cycle. ${ }^{46}$ When VUWSA purchased a new typesetter late in 1985, it was faulty, breaking down and being fixed nearly every day for three weeks upon arrival. ${ }^{47}$ As a result, one issue of Salient went to the printers with just eight pages; issue eighteen was not able to be produced at all. Many more were produced under duress. ${ }^{48}$ As stressful as these technical issues were at face value, they also caused some tension between Hurley and NZUSA. Their officers regularly sent copy to student media throughout the country to keep students informed of what their national association was doing on their behalf. On occasion, due to issues with the typesetting machine, Salient simply ran out of time to typeset these articles. Some members of NZUSA interpreted this as politically motivated censorship of NZUSA, souring the relationship between the National Executive and Hurley. Ongoing mechanical issues, and the fact that Hurley did much of her own typesetting, meant that the technical aspects of the job "took over" to the detriment of her vision for Salient. ${ }^{49}$

Salient became a forum for discussion of homosexual law reform in the 1980s. This was one of the major human and civil rights campaigns of the time period, and Salient gave some

\footnotetext{
45 Jane Hurley, 'Sexual Harassment: Handbook' 85 clarified and explored', Salient, Vol. 48, No. 1, p.10.

46 Jane Hurley, interviewed by Max Nichol, 8 February 2019.

47 Jane Hurley, 'Editorial', Salient, Vol. 48, No. 20, p.2.

48 'No resurrection for typesetter', Salient, Vol. 48, No. 18, 5 August 1985. Due to the printing requirements of Wanganui Newspapers, the number of pages in a given issue of Salient had to be a multiple of four. It was rare that Salient ran to less than sixteen pages, and it commonly ran to twenty or twenty-four.

49 Jane Hurley, interviewed by Max Nichol, 9 February 2018.
} 
prominence to the issue. Its coverage of gay rights had been patchy in the 1970s. Roger Steele reflected, saying that he had said some "stupid things I bitterly regret" about the gay liberation movement in the 1970s. ${ }^{50}$ An editorial in 1974 took aim at the Gay Liberation Front for deigning to co-opt the revolutionary language implied by the term "liberation front" for example. While he had "certainly wanted to give gay people a voice", Steele and other Salient contributors saw gay rights as secondary. Other publications such as Cock, Earwig, and Itch had covered developments in gay liberation in more depth. Nevertheless, Salient had provided some inconsistent but sympathetic coverage to gay liberation in the 1970s. ${ }^{51}$ The use of the term "liberation front" which Steele had objected to highlighted the broad and uncompromising aims of gay liberation in the 1970s. The demands gay liberation activists made were not so much a "plea for society's consideration" but rather "an expressed desire to restructure society". 52

Salient gave more space to gay and lesbian rights in the 1980s. By then, the push for homosexual law reform had become more conciliatory. Due to conservative backlash against gay liberation, the movement "argued in liberal terms, and repeatedly referred to individual human rights. The revolutionary account of social change that characterised the discourse of 1970s Gay Liberation had disappeared". ${ }^{53}$ The focal point of this was the push for the passage of the Homosexual Law Reform Bill, introduced by Member of Parliament Fran Wilde in 1985. As Jasmine Freemantle has explained, Hurley's editorials demonstrated open support for the Bill throughout her year as editor, charting some of its progression through the House of Representatives. ${ }^{54}$ When the Bill became law in 1986, Jon Lusk wrote about the significance of the decision in Salient's regular gay and lesbian column. He was generally unimpressed with New Zealand's parliamentarians who took "16 months of umm-ing and arr-ing, to decriminalise sex between males over 16". However, he felt the campaign had achieved alleviating some of the stigma attached to being gay, before turning his sights towards "achieving equality (not just legality) for gay men and lesbians". 55

\footnotetext{
${ }^{50}$ Roger Steele, interviewed by Max Nichol, 16 December 2018.

${ }^{51}$ See for example Barry Nonweiler, 'Gays persecuted', Salient, Vol. 39, No. 16, 12 July 1976, p.7.

${ }^{52}$ Chris Brickell, "Sexuality, Morality and Society," in The New Oxford History of New Zealand, ed. Giselle Byrnes (Melbourne: Oxford University Press Australia \& New Zealand, 2009), p.480.

${ }^{53}$ Brickell, p.481.

${ }^{54}$ Freemantle, "Constructing Queer in Student Media," pp.8-9.

55 Jon Lusk, 'Gay Forum', Salient, Vol. 49, No. 15, 21 July 1986, p.17.
} 
The column to which Lusk was one contributor was a way in which Salient gave more regular space to gay and lesbian rights in the 1980s. The gay and lesbian column dealt with wider experiences of being homosexual in New Zealand, outside of the Homosexual Law Reform campaign. Stephen Hamilton asserts that there was a gay and lesbian column titled "Out on Campus" from 1989. ${ }^{56}$ In fact this column existed from 1983, and was published consistently under a number of titles including "Gay Forum", "Gay lesbian forum", and "Out on Campus". The first of these columns declared that as the "liberation movements have broken the closet cycle to some extent by vigorous assertion of our rights ... the Lesbian/Gay Students' Forum aims to keep the momentum up and make it easier for lesbians and gay men to come out - accept one's sexuality and not hide it". ${ }^{57}$ The column celebrated homosexuality, seeking to normalise it amongst students at VUW as well as highlighting the difficulties faced by VUW's increasingly visible homosexual community.

Salient's coverage of Māori issues in the early to mid-1980s grappled unevenly with the most radical elements of Māori activism at that time. Some of the leadership of Halt All Racist Tours (HART), an organisation which was "at the forefront" of the anti-tour movement, were WCL members, who forged alliances with anti-tour Māori women activists such as Donna Awatere and Ripeka Evans. ${ }^{58}$ Through WCL, HART, general student opposition to the tour, and Stephen A'Court's deliberate use of Salient as an anti-tour organ, Salient too was a subsidiary component of this alliance. However, this cooperation broke down after the tour ended. Evans and Awatere had expected that the enthusiasm Pākehā activists had displayed for opposing racism in South Africa might be applied to racism against Māori and Pasifika people in New Zealand. This did not eventuate to any great degree. Evans and Awatere were angry and disappointed with groups like the WCL, who had supported the anti-tour movement but failed to prioritise an analysis of racism in New Zealand, clinging to a class-based analysis. As Margie Thomson explained, Māori sovereignty was perceived as something of a threat, because it was "outside the party". ${ }^{59}$ To this end, on the occasions when the WCL supported Māori activists on Māori issues, it was framed as

\footnotetext{
${ }^{56}$ Hamilton, A Radical Tradition, p.198.

${ }^{57}$ Neil Anderson and Kathy Hall, 'Lesbian Gay Student Forum', Salient, Vol. 46, No. 1, 28 February 1983, p.21.

58 Locke, “Maori Sovereignty, Black Feminism, and the New Zealand Trade Union Movement," p.262.

${ }^{59}$ Margie Thomson, interviewed by Max Nichol, 9 December 2018.
} 
working class solidarity, rather than opposition to racism faced by Māori and the ongoing consequences of colonisation. ${ }^{60}$

This resistance to Māori radicalism filtered through VUWSA, which in the early 1980s still had a relatively significant WCL component. Following the tour, the NZUSA National Executive made addressing domestic racism one of its flagship campaigns issues for $1982 .{ }^{61}$ Part of this involved organising a speaking tour of campuses around the country featuring Black women speaking about the stark realities of racism in New Zealand. VUWSA objected to the tour on the grounds that it featured Ripeka Evans. Evans was a contemporary of Donna Awatere and was a prominent figure in both the 1981 Springbok Tour and the Māori sovereignty movement. She drew the ire of the VUWSA Executive for comments she made at a "Nuclear Free and Independent Pacific" conference in Suva in 1981. She had called the NZUSA delegates to the conference “"white clones' sent to Fiji to split the Pacific peoples' unity". ${ }^{62}$ VUWSA took the position that NZUSA should not be supporting individuals who openly maligned their organisation. Furthermore, they disagreed with what they perceived as a divisive disposition that held that "all whites are racist; that whites are "the enemy"; and ... that racism is a white problem, that blacks are not racist. The Vic Exec decided it would not support an anti-racism tour at which a speaker held and expressed "such racist views"". 63

Despite commitment to supporting Māori issues and an end to racism in principle, like many Pākehā activists, the VUWSA Executive struggled to grasp the scope of Evans' and Awatere's idea of Māori sovereignty. Awatere was not interested in simply ending racism, but in the withdrawal of Māori from Pākehā institutions and, more generally, the capitalist, patriarchal, colonial state of New Zealand. ${ }^{64}$ Pākehā liberals found these ideas challenging. Jacob Pollock describes the "anxiety of settlement" amongst Pākehā during the 1981 Springbok Tour. Pākehā who both supported and opposed the tour had to grapple with the myth that New Zealand's race relations were uniquely harmonious. ${ }^{65}$ This myth was well articulated by Henry Isaacs, the South

\footnotetext{
${ }^{60}$ Locke, "Maori Sovereignty, Black Feminism, and the New Zealand Trade Union Movement," p.263.

61 'NZUSA May Counci', Salient, Vol. 45, No. 11, 31 May 1982, pp.8-9.

${ }^{62}$ Anna Mackenzie, 'Vic hits back!', Salient, Vol. 45, No. 5, 29 March 1982, p.16. This was the same conference at which Evans had presented a paper "articulating a demand for Māori sovereignty" which set in motion a falling out with Northern Drivers' Union official Bill Anderson.

${ }^{63}$ Anna Mackenzie, 'Vic hits back!', Salient, Vol. 45, No. 5, 29 March 1982, p.16.

${ }^{64}$ Locke, “Maori Sovereignty, Black Feminism, and the New Zealand Trade Union Movement," p.263.

65 Jacob Pollock, "'We Don't Want Your Racist Tour': The 1981 Sprinbgbok Tour and the Anxiety of Settlement in Aotearoa/New Zealand," Graduate Journal of Asia-Pacific Studies Vol. 2, no. 1 (2004): p.36.
} 
African NZUSA Scholar, in 1976. Isaacs stirred controversy amongst the student body with a guest editorial in Salient titled "A Rhodesia in the South Pacific" which opened by flatly stating: "New Zealand is probably the most racist country in the world ... [New Zealanders] still attempt to perpetuate the lie that this is the perfect multi-racial society" ${ }^{66}$ Pākehā insecurity produced by the tension between New Zealand's imagined racial harmony and the ongoing violence caused by colonisation, described by Evans and Awatere, led some Pākehā to reject any organisation which privileged Māori. Institutions such as the New Zealand Māori rugby team or the Department of Māori Affairs were therefore seen as "an example of racial segregation" akin to apartheid. ${ }^{67}$ It was on these grounds that VUWSA objected to Evans' speaking tour.

Salient's engagement with the ideas of Māori sovereignty was more ambiguous than VUWSA's. Similar to VUWSA, the newspaper struggled to grasp the more challenging rhetoric of the likes of Awatere and Evans. However, it also platformed their ideas. A report on Waitangi Day protests in 1982 for example carried the title "The Treaty is a fraud", a direct reference to the refrain of Māori activists in the 1970s and 1980s who sought to shatter the perception that the Treaty of Waitangi formed the basis of a harmonious bi-cultural nation. ${ }^{68}$ Furthermore, despite VUWSA's protests, Evans and Peta Siulepa did conduct an NZUSA-backed tour of university campuses in the second term of 1982. At VUW they spoke in the Union Hall on 8 June. The Salient issue for the week prior to their talk featured publicity material for the tour which primed the audience for some of the ideas they could expect. It addressed the fact that New Zealand was governed by Pākehā traditions and norms, by which its "health, education, justice, employment and political systems practise institutional racism. Maori and Pacific Islanders experience this racism in every aspect of their lives" ${ }^{69}$ Salient's coverage on the talk itself was mostly a verbatim report of Siulepa and Evans' main points about racism in New Zealand. Notably, they expressed the view that what "white socialists groups want is the replacement of one white structure with another white structure". However, the article did not necessarily imply support for Siulepa and Evans' ideas. Its framing belied frustration that they had not provided enough concrete solutions

\footnotetext{
${ }^{66}$ Henry Isaacs', 'Editorial: A Rhodesia in the South Pacific', Salient, Vol. 39, No. 10, 24 May 1976, p.2.

${ }^{67}$ Pollock, "We Don't Want Your Racist Tour," p.39.

${ }^{68}$ Cilla Morris and Toni Davis-Waho, 'The Treaty is a fraud', Salient, Vol. 45, No. 1, 1 March 1982, p.6.

69 'Black women speaking tour', Salient, Vol. 45, No. 11, 31 May 1982, p.4.
} 
to racism, particularly for Pākehā wanting to do better, concluding that "what was lacking was an answer to "it's bad, but what can we do?"". ${ }^{70}$

Salient also published a direct response to Donna Awatere's Maori Sovereignty, a series of articles published first in the feminist publication Broadsheet in 1982 and 1983, then as a standalone volume in $1984 .^{71}$ Awatere articulated a strong and uncompromising need for Māori self-determination through political organisation which was by and for tangata whenua. Salient's response to these articles provided a "Pakeha Viewpoint". It did not deny the existence of racism against Māori in New Zealand, historically or in the 1980s. Its author referenced Keith Sinclair's A History of New Zealand as an example of a historical narrative which brushed over some of the worst of the colonial violence in New Zealand, crediting Awatere with providing "the first tentative steps of a counterbalancing historiography". However, the rest of the article attempted to walk back Awatere's more radical suggestions. Its author disagreed with Awatere's assertion that trade unions acted against Māori interests, as they were "based on individualistic principles, incompatible with communal Maoritanga", arguing that trade unions were "the only lefties with any money" and that what Awatere considered "tokenistic" gestures towards Māori sovereignty were in fact evidence of concrete trade union support for Māori. ${ }^{72}$ The article distils the reaction many Pākehā leftists had to radical Māori sovereignty - Māori may have been hard done by, and New Zealand may not be the racially harmonious society it purported itself to be, but "separatism" was not the answer.

Despite being controversial amongst many Pākehā liberals, Awatere's analysis did have a significant effect on the women's movement, and upon organised leftist groups. This included the WCL. Its members re-examined their analysis in the early 1980s, considering the ways in which race and gender compounded and interacted with experiences of class exploitation. ${ }^{73}$ This manifestation of class analysis was known as tripod theory, and it was part of a wider trend on the left in New Zealand which gained currency throughout the 1980s. This was thanks to theorists such as Awatere and Evans, in addition to publications such as Race Gender Class and The Republican which adopted, advanced, and applied this mode of analysis to the context of capitalism in New Zealand. However, not all members of the WCL saw the value in moving away

\footnotetext{
70 'Tour start, anti-climax', Salient, Vol. 45, No. 13, 14 June 1982, p.4.

${ }^{71}$ Locke, “Maori Sovereignty, Black Feminism, and the New Zealand Trade Union Movement," p.263.

72 Peter Fuller, 'Awatere: A Pakeha Viewpoint', Salient, Vol. 46, No. 22, 12 September 1983, pp.8-9.

${ }^{73}$ Chamberlain, Constant Radical: The Life and Times of Sue Bradford, p.160.
} 
from a strictly class-based analysis. As Bradford notes, "old-style communists were really hostile to all that stuff". ${ }^{74}$ Ron Smith for example felt the adoption of tripod theory was overall detrimental to the effectiveness of the WCL, writing that its "earlier stance of class against class, with the revolutionary concept of the working class taking power under the leadership of a Marxist party, got diluted". Support for trade unions, women, and Māori became "ends in themselves rather than avenues to build the Party and the socialist revolution". 75

The notion that established Pākehā organisations did not understand or adequately represent Māori found proponents among Māori students at VUW. The prominence of Māori students and Māori knowledge at VUW increased in the 1980s. The establishment of Te Herenga Waka marae on Kelburn Parade provided a focal point for Māori students and staff. The marae was opened officially in 1980. It operated at first out of one of the university-owned houses on Kelburn Parade, then in a purpose-built whare whakairo from 1986. Its establishment and development represented the growing prominence of Māori Studies as a discipline which was distinct from Anthropology, the department in which Māori Studies was first founded at VUW. ${ }^{76}$ Despite this growing visibility of Māori students and knowledge within the university, the student population of VUW was still overwhelmingly Pākehā in the 1980s - just 3\% of students were Māori in $1986 .{ }^{77}$ For Māori Language Week in 1985, Salient published reflections from Māori students on their experience of being Māori at university. These experiences dealt with the isolation that came with being in an institution dominated by Pākehā. As one student explained, her experience of the "soft overflowing aroha most Maoris display towards each other ... was replaced by the hard, sharp confines of the pakeha structure at university" ${ }^{78}$

In 1985, following a hui at the marae, Māori students indicated that they felt that SRC was not representing their interests. Māori issues rarely came up on the agenda, and when Māori students proposed motions relating to Māori issues these were often not debated or voted upon. The solution was the proposed formation of Te Runanga Tauira o Aotearoa, "a national body of Maori University students, which would have the ability, power and recognition to represent Maori students effectively" ${ }^{79}$ This proposed Māori student organisation was about self-determination,

\footnotetext{
${ }^{74}$ Chamberlain, p.160.

75 Smith, Working Class Son, p.164.

${ }^{76}$ Barrowman, Victoria University of Wellington 1899-1999: A History, pp.254-5.

77 Barrowman, p.315.

${ }^{78}$ Kurutia Seymour, 'A First Year Maori Student at University', Salient, Vol. 48, No. 16, 22 June 1985, p.7.

79 Grant O’Neill, 'voice for Maori students', Salient, Vol. 48, No. 16, 22 June 1985, p.3.
} 
and can be read as an expression of the ideas of Māori sovereignty. Māori students would still have the right to vote and participate in SRC where issues were relevant to all students, while reserving the right to have issues which only affected Māori students be discussed through a more appropriate channel.

A student organisation for Māori separate from NZUSA did eventuate in 1986. Māori had had representation on NZUSA since 1983, through Nga Toki, a national committee which convened at NZUSA Councils to discuss issues pertaining to Māori students. The following year the National Executive had its first Māori National Officer, a new position filled by Tony Waho of Te Ati Awa, a student at VUW. He and his successor in 1985 found the position overwhelming given the sheer volume of work which needed to be done to improve the situation for Māori students. Nga Toki managed to secure a second Māori National Officer, collectively known as the Tumuaki Maori Collective in $1986 .^{80}$

The 1986 NZUSA reforms provide another instance in which Salient simultaneously platformed calls for Māori self-determination, while questioning the need for such actions. May Council for 1986 was a particularly fraught conference. The Auckland University Students' Association had threatened to leave NZUSA, and Salient editor Richard Adams and VUW delegates reported a disorganised and tense series of discussions about the future viability of NZUSA as an organisation. ${ }^{81}$ For Nga Toki and NOSAC, the NZUSA Committee representing overseas students, it was an opportunity to air their grievances with the rest of NZUSA. Speaking on behalf of both organisations, Manu'a Poloai addressed the closing plenary with a blistering rebuke of the bureaucracy of NZUSA and their inadequate support for students from ethnic minorities: "We are not going to change for you - you have to change for us. You people are fucking yourselves around at our expense ... It's your problem as pakeha people. We have got what we want. We won't compromise. We are opposed to any proposal you put forward". ${ }^{82} \mathrm{Nga}$ Toki and NOSAC were concerned that reforms would dismantle the representation they had worked for in NZUSA. They proposed an amendment to the motion which would prevent their terms of reference of the restructure from interfering with Nga Toki, Tumuaki Maori, NOSAC, and the Overseas Vice President as they stood.

\footnotetext{
${ }^{80}$ Mate Paihana, 'Unity for Nga Toki', Salient, Vol. 49, No. 24, 6 October 1986, p.6.

81 Richard Adams, 'Anatomy of a Council', Salient, Vol. 49, No. 9, 26 May 1986, pp.6-9.

82 Richard Adams, 'Anatomy of a Council', Salient, Vol. 49, No. 9, 26 May 1986, pp.6-9.
} 
Adams made his thoughts on separate national representation for Māori students clear. He was conflicted listening to Te Aniwa Tutara, one of the two members of Tumuaki Maori, make her case for the amendment. He found himself "agreeing with what she was saying but knowing that the amendment had to be defeated". His opposition to the amendment was based on the belief that the overall integrity of NZUSA was more important than the organisation "be a microcosm of the society it lives in". He felt that it was important that NZUSA try to represent Māori students cohesively, and that if Māori students had lost faith in NZUSA "then the organisation must attract them back. They should want to join NZUSA, because it is effective. Or will be effective". ${ }^{83}$ Evidently, Adams did not perceive much value in separate representation for Māori students, even representation from within the structure of NZUSA. His support for Tutara's views in principle gave way to his views on the procedural and constitutional integrity of NZUSA as a whole, expecting Tumuaki Māori and Nga Toki to "compromise" to achieve this integrity.

NZUSA reforms led Māori to establish a separate national organisation for Māori students, Nga Toki o Aotearoa. As part of the transition from NZUSA committee to autonomous organisation, NZUSA funded the organisation for the first three years of its existence. ${ }^{84}$ Adams' own opinions on Māori student representation presented some contradiction within Salient. Nga Toki delegates and VUW students Hone Whaanga and Paora Ammunson expressed their support for separate representation in Salient in 1986. This was often in terms which, like Poloai's speech, expressed anger and frustration with the Pākehā perspectives which informed NZUSA's structure and its decisions around restructuring. They were not at all confident that the entirely Pākehā working group would adequately consider the effects of a restructure on Māori students. ${ }^{85}$ These students were unapologetic in their criticisms of NZUSA and the way in which its restructure process was likely to marginalise Māori perspectives.

Ultimately, the restructuring of NZUSA demonstrates further the difficulty Pākehā contributors to Salient had in accepting measures of independent representation for Māori. In the early and mid-1980s, Salient published articles which gave the powerful critiques of Awatere some measure of exposure. However, it also published articles by Pākehā expressing their scepticism of “separatism" as an effective means of improving New Zealand's race relations. On issues of gender

\footnotetext{
${ }^{83}$ Richard Adams, 'Anatomy of a Council', Salient, Vol. 49, No. 9, 26 May 1986, pp.6-9.

${ }^{84}$ Mate Paihana, 'Unity for Nga Toki', Salient, Vol. 49, No. 24, 6 October 1986, p.6.

${ }^{85}$ Hone Whaanga and Paora Ammunson, 'Te Puna O Te Rangatahi', Salient, Vol. 49, No. 12, 16 June 1986, p.7.
} 
and sexuality, Salient reflected contemporary developments. Its first women editors in over forty years came at a time when more women were attending university and going onto hold positions which had historically been the realm of men, as was the case for the editor's chair at Salient. As editor, Hurley supported the Homosexual Law Reform Bill which decriminalised sexual activity between consenting adult men, and more generally Salient established a column within the newspaper to forefront gay and lesbian voices which ran throughout the 1980s. Through engaging with these kinds of issues, Salient remained involved in political developments on the left.

\section{The Labour Government and Opposing User Pays Tertiary Education}

The second half of the 1980s brought new challenges to universities. The NZUSA restructure was not just about whether Māori students should have their own association. It was a response to the growing threat of "user pays" education, an idea which was gaining traction by the mid-1980s. Salient heralded the election of a Labour Government in 1984 as a victory in the campaign against funding cuts for universities. However, Roger Douglas' radical economic reforms did not leave education untouched. Official reports on new models of funding universities were released late in Labour's second term, and implemented by a National government, but the ideas had percolated for a while. Minister for Education Russell Marshall and Associate Minister Phil Goff were increasingly convinced it was necessary and justifiable to place more of the financial burden of studying upon students, and to reorient tertiary institutions around a market model in line with the rest of the public sector. Universities faced increasing expenses but did not have the funds to keep up. They got in ahead of the Government, introducing measures of user pays and capping student numbers, compromising the principle of open access. The gravity of this threat had implications for the priorities of student politics and Salient. Both NZUSA and VUWSA underwent major reforms in an effort to be more responsive to student interests and protect student support, instead of addressing broader political issues. For VUWSA, "moderate" and right-wing Executive members had laid some of the groundwork for this to occur. Salient followed suit - this was a less deliberate and codified change than was the case for NZUSA and VUWSA. Developments in the debate around education funding simply came to dominate the pages of Salient as the need to oppose user pays became more urgent. The paper's editors used the platform to publish analysis criticising user pays, organise action against it, and feature interviews with relevant politicians. This is not to say Salient was no longer political - opposing Government user 
pays policies was inherently political, and other political and social issues were still discussed, as we shall see. However, as student access to tertiary education was threatened, Salient devoted far more of its coverage to education issues; its role as an advocate for student interests came to the fore.

In the early 1980s, the familiar issues of cuts to university staffing and bursaries were exacerbated. The cuts to Government funding for student services which the 1980 Education Fightback campaign had pushed against went ahead at the end of that year. ${ }^{86}$ In 1982 , the University Council at VUW voted to drastically cut subsidies for welfare services, a significant deviation from the Hughes Parry Report which had recommended funding these services in the first place. ${ }^{87}$ Spending per student went from $\$ 92.18$ per student to $\$ 15.52$, for a gross cut of $\$ 70,000$. Some, but not all, of this cut was to be made up by an annual levy of $\$ 12$ on all students. ${ }^{88}$ Meanwhile, the Student Community Service Programme (SCSP) which had found students paid community work over the summer was axed in 1982, despite being hailed as a mutually beneficial collaboration between students and the community in an environment of high unemployment. Leaked Cabinet documents revealed that the Government was aware that "axing SCSP would dump 3,750 students on the dole this Christmas ... Students seeking work will now be competing in the private sector with the unemployed. Those whose cause is the same will be set against each other" ${ }^{89}$ Whereas pushback against cuts in the 1970s had been somewhat effective, the debate in the 1980s increasingly revolved around a totally different set of terms. Salient followed the debate on user pays closely, opposing it at every step of the way. The threat it presented to students meant that it occupied a significant amount of Salient's coverage in the 1980s. By 1984, the fears of 1970s student journalists and politicians had been realised. They had fought against funding cuts in the hopes of maintaining government support to enable students from a range of financial backgrounds to attend university without having to rely on family wealth. But a 1984 survey of enrolling students found that "in common with New Zealand's other universities, Victoria drew its students from a "narrow range at the higher levels of socio-economic status". 90 The Muldoon years had taken their toll on universities.

\footnotetext{
${ }^{86}$ Stephen A'Court, 'Editorial', Salient, Vol. 43, No. 26, 6 October 1980, p.2.

${ }^{87}$ Hamilton, A Radical Tradition, p.192.

88 'Vic actions cuts', Salient, Vol. 45, No. 10, 10 May 1982, pp.1, 4.

${ }^{89}$ Mark Cubey, 'SCSP axed: what does it mean?', Salient, Vol. 45, No. 14, 6 July 1982, pp.9-10.

90 Barrowman, Victoria University of Wellington 1899-1999: A History, p.315.
} 
At the same time, political action on education stalled after Education Fightback. While students such as Margie Thomson had found the 1981 Springbok Tour energising, others felt "burnt out" after the immense effort it had taken to oppose the tour. ${ }^{91}$ At NZUSA's 1982 May Council, there was "general despondency" at the lack of interest students had shown in the Cost of Learning campaign, the spiritual successor to Education Fightback. ${ }^{92}$ In 1989, Cubey recalled that in 1982 and 1983, to get "two or three hundred people" to a protest was "quite an achievement - partly because there were no pressing education issues. There were the political issues but ... time for students was getting less and less, and there wasn't the energy". 93 The election of a Labour Government in 1984 also brought optimism. The First Labour Government and the sweeping social reforms and public spending it had brought were still in living memory. ${ }^{94}$ In a reflective late night editorial, Zwartz captured the exhaustion of nine long years of Muldoon, saying that flicking through this week's Salient "I felt as though I were being presented with a composite picture of NZ 80s bleakness". ${ }^{95}$ By contrast, her mood on election night was one of excitement, though tinged with suspicion of Labour's intentions:

Labour can only be an improvement ... the departure of Mervyn Wellington should be welcomed with glee. And good night Couch, Malcolm, Templeton - such a relief to see them go. No great faith can be placed in the Labour Party, though, until they've made their intentions clear ... do the rumours about Douglas' plan for recovery inspire confidence? Is he in the right party? And no-one holds Labour accountable for the currently taut relationship between unions and the government - but will Lange, with his stupidly cautious attitude towards non middle-of-the-roaders improve matters much? ${ }^{96}$

The optimism that came with Lange's Government carried over into 1985. There was a sense that with Russell Marshall as Minister for Education, "everything would be wonderful in education". It seemed there was at last a Minister for Education who was sympathetic to the financial plight of students and would revitalise tertiary education funding. ${ }^{97}$ The social reforms

\footnotetext{
91 Mark Cubey, 'Salient looks back on 1982 and 1983', Salient, Vol. 52, No. 22, 11 September 1989, p.24; Mark Cubey, interviewed by Max Nichol, 5 December 2018; Simon Wilson, interviewed by Max Nichol, 8 December 2018.

92 'NZUSA May Council’, Salient, Vol. 45, No. 11, 31 May 1982, pp.8-9.

93 Mark Cubey, 'Salient looks back on 1982 and 1983', Salient, Vol. 52, No. 22, 11 September 1989, p.24.

94 Belgrave, From Empire's Servant to Global Citizen: A History of Massey University, p.380.; Roger Steele, interviewed by Max Nichol, 16 December 2018; Jane Hurley, interviewed by Max Nichol, 9 February 2019.

95 Sally Zwartz, ‘Editorial’, Salient. Vol. 47, No. 11, 5 June 1984, p.2.

${ }^{96}$ Sally Zwartz, 'Editorial', Salient, Vol. 47, No. 15, 16 July 1984, p.12.

97 Jane Hurley, interviewed by Max Nichol, 9 February 2019.
} 
of David Lange's Government buoyed this sense that the "country was in good hands" - they were “moving on the old issues (South Africa, gay rights, women's rights, nukes and everyone thought it sweet". 98

Despite this optics of progressiveness on social reforms, economically, Zwartz's suspicions of Roger Douglas proved to be well-founded. His neoliberal economic policies, colloquially known as Rogernomics, gutted the public sector. Labour's first term saw state assets deregulated and the State Owned Enterprises Act 1986 saw "specified state enterprises ... operate on the same basis as private enterprises, with boards independent from political control". ${ }^{99}$ Their second term went further. The "1988 Budget announced sweeping privatisations" of state-owned corporations such as the Bank of New Zealand and Telecom. Privatisation was intended to allow these corporations to operate at "maximum efficiency" through competition in a free market. ${ }^{100}$ For the problem of funding universities and students, the market solution was to be some kind of "user pays" model, wherein students stumped up more for their own tertiary education.

The idea of a user pays system for education had been circulating since the early 1980s. Salient reported on the 1982 actions taken by the Australian Union of Students to oppose a user pay systems in Australia. The report noted that New Zealand was often close to follow Australia in tertiary education policy, as had been the case with the introduction of a $\$ 1500$ fee for international students in 1979. This trend meant that "the struggle of Australian students against loans [is] vitally important to us". In a private precursor to user pays education, student loans also began to be available through private banking. In 1981, the National Bank offered a loan scheme aimed specifically at students called the "Bursary Backstop". Its use of the language of public funding for students was a "damning indictment of the failure of the current bursary system (and an economy which saw over $20 \%$ of university students registered unemployed over summer)". ${ }^{101}$ Other banks offered similar schemes to students in the 1980s, with perks such as low interest loans and low or no interest overdrafts. This allowed banks to acquire new customers while simultaneously softening students to the idea that studying required taking on personal debt. ${ }^{102}$

\footnotetext{
98 Jane Hurley, interviewed by Max Nichol, 9 February 2019; Mark Cubey, 'Salient looks back on 1982 and 1983', Salient, Vol. 52, No. 22, 11 September 1989, p.24.

99 McAloon, Judgements of All Kinds: Economic Policy-Making in New Zealand 1945-1984, p.204.

100 McAloon, pp.205-7.

101 Stephen A'Court, 'Editorial, Salient, Vol. 44, No. 1, 2 March 1981, p.11.

102 Mike Houlahan, 'Banking For Life', Salient, Vol. 50, No. 6, 13 April 1987, p.3.
} 
User pays models of tertiary education began to be considered more seriously in 1986 . Minister for Education Russell Marshall floated the possibility of either a tax on university graduates or a student loans system to recover some of the costs of studying. Following similar policy in Australia, he was also considering offering "spaces" at New Zealand universities to overseas students who paid their own fees in full. Salient perceived this discussion as a canary in the coalmine for domestic students - "Most definitely it is all part and parcel of the Government trying to run the education system on a free market basis ... where education is a commodity sold to the highest bidder". 103

Student politics and Salient changed the nature of their operations to face this new threat, honing in on student interests and education policy. Following the adoption of an Independent Working Group's recommendations at August Council in 1986, NZUSA was re-established as a "broadly based student federation working on education and welfare issues". 104 VUWSA underwent similar changes. Andrew Little, VUWSA President in 1987 and NZUSA President in 1988-1989, believed that "education is one of, if not the most important area in which VUWSA can and must work". ${ }^{105}$ Little attempted to institute constitutional reforms in 1987 which would bring VUWSA's activities in line with this view. He wanted to cut some politically focussed Executive positions to make for a leaner Executive more focused on the issue of education, and to use Association funds to commission research into education to better inform these aims. ${ }^{106} \mathrm{~A}$ piece of analysis in Salient the following year explained that the "current system was designed for numbers of students who are not interested in student activism any more". ${ }^{107}$ For those in favour of reforming VUWSA, the entire apparatus of the Association no longer suited the needs of the current cohort of students. These students did not have the time or the interest in politics in the same ways their predecessors had, but they were faced with much greater threats to the financial security which allowed for their studies. VUWSA would have to change accordingly.

\footnotetext{
${ }^{103}$ Louise Mason, 'user pays university', Salient, Vol. 49, No. 19, 18 August 1986, p.5.

104 Richard Adams, 'Council of Change', Salient. Vol. 49, No. 20, 8 September 1986, p.4.

${ }^{105}$ Andrew Little, 'president', Salient, Vol. 50, No. 4, 23 March 1987, p.2.

${ }^{106}$ Belinda Howard, 'Salient steps into its time machine and sets the dial for 1986 and 1987', Salient, Vol. 52, No. 24, 25 September 1989, p.6.

107 Steve Cosgrove, 'Shape of things to Come', Salient, Vol. 51, No. 6, 11 April 1988, p.10.
} 
VUWSA was substantially reformed along the lines Little envisioned, though not until 1988. ${ }^{108}$ The Independent Working Group VUWSA commissioned believed the Association was spreading itself too thin, to the detriment of doing a few things very well. As the only student association based in Wellington, and therefore a stone's throw from "the Beehive, ... the University Grants Committee, Treasury, and the country's major media outlets", the group felt VUWSA was "too important to be just okay, it has to be brilliant". Their report suggested wideranging changes to the structure and purpose of VUWSA. It suggested that VUWSA coalesce around eight core principles, three of which related to education and just one of which related to "Public Issues". The Executive was to be streamlined, with just nine officers, three of which dealt with education. Portfolios which had a political element, such as International Affairs Officer, Woman Vice-President, and Māori Student Officer were to be removed. In essence, the proposed restructure massively narrowed the political action of VUWSA down to a focus on education. VUWSA would lobby the government and university on behalf of students and administer student affairs on campus to create the best possible academic environment. The constitutional architecture of VUWSA established in 1968, which had broad political aims, was perceived as no longer fit for purpose in an era when New Zealand was undergoing fundamental neoliberal reform of its tertiary sector. $^{109}$

These recommended Constitutional changes were adopted in full at a Special General Meeting late in 1988. The new Constitution was "radically different from the old one. The goals of the Association are to be focussed more narrowly on education issues and the provision of services to students, and less on SRC-centred public issues". ${ }^{110}$ The decision abolished SRC and its officers. SRC was replaced with the more toothless Forum, which involved regular meetings where students could discuss what they wished, with the crucial difference that these meetings no longer set Association policy. NZUSA and VUWSA reform massively de-centred political activity which did not relate directly to tertiary education. NZUSA Women's Officer Ann Webster explained that the "image is changing. When I first got involved in student politics it was with a great deal of reserve. But now that our priorities are re-organised and we are focussing on

\footnotetext{
108 Little's reforms were passed in 1987 at an inquorate meeting, and as such the reforms were declared null. Steve Cosgrove, 'Shape of things to Come', Salient, Vol. 51, No. 6, 11 April 1988, p.10.

109 'All Shook Up', Salient, Vol. 51, No. 17, 28 July 1988, p.6.

110 'Studass Changes Pushed Through', Salient. Vol. 51, No. 24, 26 September 1988, p.3.
} 
education and how university life affects students, the perception of student politicians as left-wing fanaticists [sic] is breaking down". 11

The Independent Working Group's report did not touch explicitly on Salient's function as a publication which could comment on political issues not relating to education. However, it clearly saw Salient's most valuable asset as its ability to act as a "watchdog” on the Executive and the newly formulated Council of Student Delegates. ${ }^{112}$ To this end, they proposed a charter which would ensure dual accountability between Salient and VUWSA to protect Salient's "right to criticise, and comment on, the performance of the Association and its Officers, and which outlines the Association's right to expect coverage of the year's priority goals". ${ }^{113}$ While it did not forbid Salient from taking stances on political issues, this recommendation essentially suggested that Salient's primary role should be reporting on the Association's activities and created a greater obligation to do so.

However, by 1988 Salient had already begun to naturally focus more of its coverage on education. While other issues did see coverage in Salient, the politics of education edged out other areas of Salient's coverage. The newspaper's editors in the second half of the 1980s recognised that user pays presented a new and more dangerous threat to the financial relationship between universities, government, and students than National's education cuts had. They used the platform to try to re-energise student opposition to these changes, taking a clear political stance against what they represented - an attack on the principles of open access to tertiary education. Adams had a keen interest in student politics and had been involved in VUWSA prior to his editorship. He was described as the "chief gossip in this place" with a shrewd eye for "any underhandedness, deceit and plain corruption" in student politics. ${ }^{114} \mathrm{He}$ was a strong believer in the necessity of NZUSA reform to protect its integrity at a time when it needed to present united and coherent opposition to user pays education. ${ }^{115}$ In 1986, Adams noted that not even Merv Wellington had proposed the "sorts of moves that Russell Marshall ... has", yet students were not taking action. Meanwhile, National had "gone even further to the right", fully endorsing the need for a user pays system. ${ }^{116}$

\footnotetext{
${ }^{111}$ Dean Carroll, 'New for you', Salient, Vol. 51, No. 2, 7 March 1988, p.7.

112 The Council of Student Delegates were students nominated to sit on various Boards and Committees within the formal university structure.

113 'All Shook Up', Salient, Vol. 51, No. 17, 28 July 1988, p.6.

${ }^{114}$ Vidva Dinamani and Ann Frankel, 'Rubbing Salt In...', Salient, Vol. 48, No. 24, 30 September 1985 , p.7.

115 Richard Adams, 'Anatomy of a Council', Salient, Vol. 49, No. 9, 26 May 1986, pp.6-9.

116 Richard Adams, 'editorial', Salient, Vol. 49, No. 21, 15 September 1986, p.2.
} 
The following year, Salient reported that "Government and Opposition are adamant savings have to be made in the education sector" indicating that both had endorsed the idea that "university students would pay more for their education". ${ }^{117}$ A political consensus on some measure of user pays was forming in front of students' eyes.

Student protest against user pays began to gain momentum in 1987. Hurley observed that most students were just at university to gain their degree and "get on with their lives ... things have to reach a kind of a critical mass before the general [student] population takes notice" of the issues. ${ }^{118}$ In 1987, this "critical mass" became apparent as universities began to introduce user pays measures. Universities placed restrictions on numbers of students, hiked fees, and introduced new courses which were not government-subsidised to solve chronic Government under-funding. Salient reported that the Vice Chancellors of Massey and Waikato were "fully in favour" of user pays measures while the Vice Chancellor at Victoria had not ruled them out for 1988. Massey introduced a number of courses in Business Studies which charged individual students the full cost of the course, while Auckland, Victoria, Canterbury, and Otago all charged higher fees for their respective courses in professional accreditation for lawyers. ${ }^{119}$ Little referred to these kinds of actions as symptoms of user pays "by stealth" on the part of the government. ${ }^{120}$ Salient's 1987 editor, Grant O’Neill, helped to organise a lecture strike followed by a march to Parliament as part of nationwide action against user pays. ${ }^{121} 2,000 \mathrm{VUW}$ students attended the march, a significant increase on prior years. However, O'Neill still felt that this was insufficient: "It was a nationwide day of support for education. Where were you? Fuck some people (no most people) are pathetic. Don't you care about education in the future?"122

A series of reports in 1988 and 1989 gave some concrete form to major tertiary education reform. Taken together, the Hawke Report and the Report of the New Zealand Business Roundtable, both published in 1988, presented different degrees of the same model for tertiary education. The Roundtable advocated for all but fully privatised universities which would compete with one another and with government research institutions for funding and for students' custom. The Hawke Report remained confident that there was still a "fundamental government

\footnotetext{
117 'User Pays', Salient, Vol. 50, No. 6, 13 April 1987, p.2.

118 Jane Hurley, interviewed by Max Nichol, 9 February 2019.

119 Bernie Steeds, 'user pays in', Salient, Vol. 50, No. 15, 13 July 1987, pp.1, 4.

${ }^{120}$ Dean Carroll, 'Student Fees may rise', Salient, Vol. 51, No. 14, 5 July 1988, p.2.

${ }^{121}$ Grant O'Neill, 'Editor', Salient, Vol. 50, No. 15, 13 July 1987, p.2.

122 Grant O'Neill, 'Editor', Salient, Vol. 50, No. 16, 20 July 1987, p.2.
} 
responsibility for tertiary education" but suggested that all tertiary institutions, including universities, polytechnics, and training colleges, be administered by a centralised bureaucracy. The report also suggested that research funding be tied to a contestable fund instead of academic staff salaries and that "general taxation could not fund the increasing expansion of tertiary education, and students would have to pay more - considerably more - to gain a degree". ${ }^{123}$ The broad vision the Report of the Business Roundtable and the Hawke Report presented found expression in Learning For Life, a two-part policy paper released in 1989 and eventually the Education Amendment Act 1990. ${ }^{124}$ In 1989, student fees were \$516, a figure which almost tripled to $\$ 1300$ in 1991, while the bursary system was "replaced by a hardly generous, means-tested student allowance scheme" in 1992. ${ }^{125}$ This was undoubtedly the most comprehensive reform of tertiary education since the Hughes Parry Report, which Rachel Barrowman describes as "more radical and less benign". ${ }^{26}$ The Hughes Parry Report had imagined university education as a public good. In line with neoliberalism's focus on the individual consumer, user pays was predicated on the idea that a university education provided private benefit to graduates through greater employment opportunities. As such, it was reasonable to expect students to pay their own way and for tertiary institutions to compete for students' custom.

Salient rejected this idea that education was a private luxury with private benefits. A guest editorial in 1988 lamented that there had been "a dramatic change in the perception amongst young people of the importance of higher education. This has centred around the notions of job prospects and greater financial renumerations ... Clouded by notions of private benefit ... we are in danger of losing the fundamental nature of education". ${ }^{127}$ The newspaper followed the reports of 1988 and 1989 closely, commenting on their content and their significance. Bernie Steeds was editor in 1988, having been involved with the newspaper since 1986. He recognised the precarity of tertiary education funding when he supported the dismissal of VUWSA President Nigel Mander. He had tried to keep Salient "aloof from the bickering which has characterised student politics in recent times". However, Mander was fairly widely considered to be incompetent, having failed to organise any substantial campaigns which would allow students to express their dissatisfaction

\footnotetext{
${ }^{123}$ Belgrave, From Empire's Servant to Global Citizen: A History of Massey University, pp.382-4.

124 Belgrave, p.383.

125 Barrowman, Victoria University of Wellington 1899-1999: A History, p.359.

${ }^{126}$ Barrowman, p.353; Belgrave, From Empire's Servant to Global Citizen: A History of Massey University, p.381.

127 Dean Carroll, 'Editor', Salient, Vol. 51, No. 16, 18 July 1988, p.2.
} 
with user pays. At a time when the Government was making solid moves towards user pays, Steeds felt that VUWSA could not afford to have an ineffective leader. ${ }^{128}$ Mander was ousted and replaced by O'Neill who revitalised the anti-user pays campaign, with the support of Steeds. Salient advertised and reported on major events in this campaign, such as a nationwide protest for education, which 3,500 people attended in Wellington, shortly after the Budget announcement revealed that $\$ 9$ million was being cut from university funding. ${ }^{129}$ Salient also provided analysis of the Business Roundtable report when it was released in June and the Hawke Report in September. ${ }^{130}$

In 1989, Salient dedicated the most coverage to education to date. Editor Belinda Howard stated that she had "decided, as editor, what direction SALIENT will go in this year - covering arts, politics and education". ${ }^{131}$ There was at least some evidence that the VUWSA reforms, as they pertained to Salient, influenced the paper in 1989. A regular news column titled "Nibbles" provided tidbits of news, mostly relating to on-campus developments and VUWSA activities, as well as minor developments in education policy. Furthermore, O'Neill, unsatisfied with Salient's coverage of VUWSA's Initial General Meeting, wrote to Howard to remind her of Salient's role as it was written in the new Constitution: "OK, so what's happened to SALIENT being the watchdog on the activities of the VUWSA Executive? ... SALIENT gets such a high proportion of student levys, and (believe it or not) it also is 'enshrined' in the Constitution. No amount of pretty full colour pages and tasteful culinary columns can excuse SALIENT's responsibility to inform students of the activities of the nine individuals who watch over many thousands of student dollars". 132

1989 proved to be a year of confusing messaging from the Government. Salient reported early in the year that Associate Education Minister Phil Goff had announced that following the recommendations of the Hawke Report, "from 1990 students will be required to pay a sum

\footnotetext{
128 Bernie Steeds, 'Editor', Salient, Vol. 51, No. 14, 4 July 1988, p.2.

${ }^{129}$ Mike Houlahan, '7000 Feet to parliament, and 9,000,000 Bucks Away From Varsities', Salient, Vol. 51, No. 18, 18 July 1988, p.5.

130 Dean Carroll, 'Students Wary of Tertiary Review', Salient, Vol.51, No. 11, 30 May 1988, p.3; Dean Carroll, 'Goff looking at user pays, SOE Unis rejected', Salient, Vol. 51, No. 14, 4 July 1988, p.2; 'Hawke Report', Salient, Vol. 51, No. 25, 7 October 1988, pp.3-4.

${ }^{131}$ Belinda Howard, 'Literary Pages', Salient, Vol. 52, No. 12, 6 June 1989, p.19.

132 Grant O’Neill, 'Chihuahua Bites Back', Salient, Vol, 52, No. 4, 20 March 1989, p.19.
} 


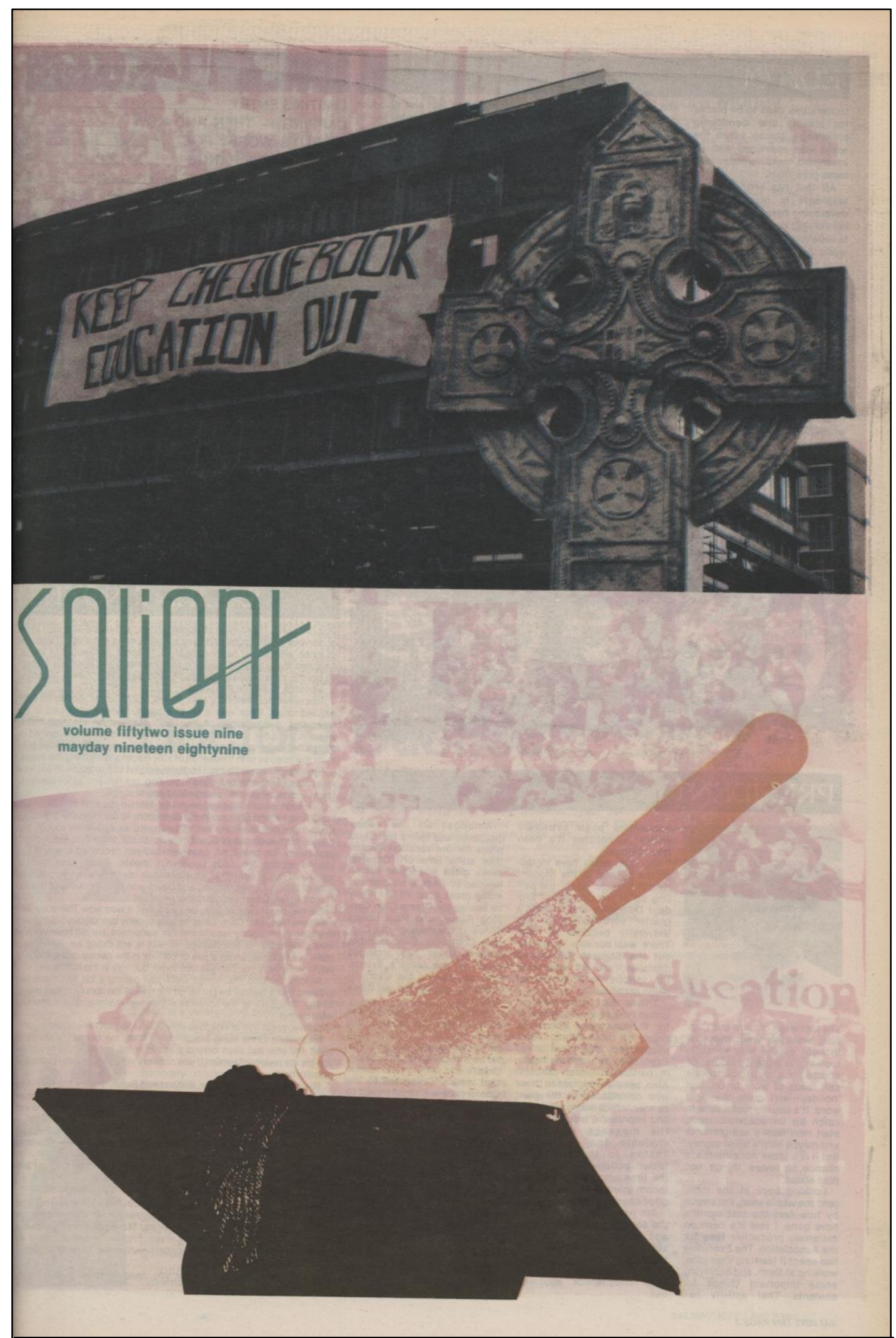

Figure 9: A photo of a banner opposing user pays education flown from the VUW's Rankine Brown Building dominated the cover of this issue of Salient. 'Keep Chequebook Education Out', Salient, Vol. 52, No. 9, 1 May 1989, p.1. 
equivalent to $20 \%$ of average tertiary education costs ... under a new loan system". ${ }^{133}$ A leaked report revealed that the introduction of a student loans scheme would, in fact, disincentivise a large number of would-be students from studying, despite the Government's assurances to the contrary. ${ }^{134}$ However, Salient scooped a big story during an off-the-cuff meeting between students and David Caygill, Douglas' replacement as Minister of Finance following the breakdown in the relationship between Lange and Douglas. Caygill's view of economic reform was much the same as Douglas', but he agreed with Lange that the market could not be relied upon for education or health. ${ }^{135}$ Seemingly out of nowhere, Caygill announced that "loans are out, finished, down the toilet, kaput". Goff initially claimed that Caygill was simply voicing his personal opinion, before reversing and announcing that as Caygill had said, student loans were off the table. ${ }^{136}$ However, this was immediately replaced by an indication that tuition fees would rise. As Howard observed, the difference between these options was nominal: "it doesn't make much difference either way. If loans or fees are introduced, it will be the beginning of a user-pays system for education". ${ }^{137}$ This fee increase was announced in late 1989. Lange had committed in principle to state-funded universities and adequate support for anyone who wanted to study during the 1987 election, a position he reiterated in 1988. ${ }^{138}$ Howard perceived the announcement of an increase in student fees to $\$ 1250$ as a clear betrayal of this position. ${ }^{139}$ A direct user pays model was avoided in 1989. In Salient's analysis however, an increase in fees for all students would accomplish the same thing. Without funding which came directly from Government, the principle of open access to universities would be compromised as university became unaffordable to those unable to pay higher fees, at the same time that under-funded universities were having to restrict entry and independently introduce user pays measures. Ultimately, user pays education was embraced in 1990 as the new National Government took Douglas' economic reforms even further to the right.

\footnotetext{
133 Rebekah Palmer, 'down, out and a loan', Salient, Vol. 52, No. 1, 27 February 1989, p.4.

134 'Report Claims Disincentive’, Salient. Vol. 52, No. 10, 22 May 1989, p.3.

135 McAloon, Judgements of All Kinds: Economic Policy-Making in New Zealand 1945-1984, p.208.

136 Belinda Howard, 'Editor', Salient, Vol. 52, No. 15, 10 July 1989, p.2.

${ }^{137}$ Belinda Howard, 'Editor', Salient, Vol. 52, No 16, 17 July 1989, p.2.

138 Dean Carroll, 'Editor', Salient, Vol. 51, No. 7, 18 April 1988, p.2; Belinda Howard, 'Editor', Salient, Vol. 1989,11

September 1989, p.2.

139 Belinda Howard, 'Editor', Salient, Vol. 1989, 11 September 1989, p.2.
} 
Fees continued to increase, and user pays education was formalised by Minister for Education Lockwood Smith through the student loans system in 1992. ${ }^{140}$

Despite the prominence of Salient's opposition to user pays in the late 1980s, other issues did see coverage. Familiar subjects such as opposing apartheid and South Africa continued to see coverage. Salient also provided some coverage of protests against the establishment of an American spy base at Waihopai in 1988. ${ }^{141}$ Continuing Salient's stance on gay and lesbian rights, O'Neill took a principled stand on the matter when he refused to publish ads in Salient from "The New Image", a group which claimed to be able to "cure" homosexuals. The ad copy was headlined “Gay?? - There is a way out!!”. Invoking his editorial discretion, O’Neill refused the ads on the grounds that "not only do they cast unwarranted doubt on the legitimacy of homosexual sexuality and therefore create or add to the confusion of homosexuals yet to come to terms with their sexuality, but they also do nothing for our largely heterosexual population, which all too often already has difficulty accepting and being comfortable with homosexuality". ${ }^{142}$

In 1989, Howard covered the controversy surrounding the purchase of Australian frigates for the New Zealand Navy extensively. ${ }^{143}$ On this issue, Salient provided information the mainstream media was unwilling to. Salient published details of a draft report of the Strategos defence review obtained under the Official Information Act which, in direct contrast to the final report, "says that the frigate purchase can not be justified on defence or economic grounds". ${ }^{44}$ Howard claimed that Salient was the only publication to have published these details. "No other media in New Zealand would touch it ... What is going on here! The media would rather sweep the truth under the carpet ... SALIENT tries to print the things that other media don't want to touch, that they consider not newsworthy". ${ }^{145}$ Even at the end of the decade as user pays education became all but certain, Salient did not entirely abandon its long-standing commitment to providing alternative coverage to what was available in the mainstream media.

\footnotetext{
140 New Zealand, Parliamentary Library, Student loans and funding for tertiary education, prepared by Dana Rachelle Peterson, 5 November 1999; Belich, Paradise Reforged, p.411.

${ }^{141}$ Bernie Steeds, 'Editor', Salient, Vol. 51, No. 15, 11 July 1988, p.2.

142 Grant O'Neill, 'Editor', Salient, Vol. 50, No. 19, 10 August 1987, p.2.

${ }^{143}$ For example, Salient printed a supplement on the issue of the frigate purchases, which explained in-depth the broad opposition to the deal. See 'No Frigates Campaign', Salient, Vol. 52, No. 8, 17 April 1989, pp.9-12.

144 'a draft blows through the defence review', Salient. Vol. 52, No. 16, 17 July 1989, pp.8-9.

145 Belinda Howard, 'Editor', Salient, Vol. 51, No. 17, 24 July 1989, p.2.
} 
In terms of the role of women in Salient in the latter half of the 1980s, Adams evinced some of the same blind-spots on gender issues as had his 1970s predecessors. A guest editorial from Melissa Clark-Reynolds to mark 103 years of women's suffrage in New Zealand came about after Clark-Reynolds suggested to Adams that he dedicate his editorial to it: "“'Old news" said the editor ... despite women's right to vote we had less of a right to work than men, less of a right to determine whether or not to have children than men and barely the right to walk alone at night without the threat of rape by men. "Old news" I hear you cry". ${ }^{146}$ Other contributors noted the gender discrepancy in the creation of Salient over the years. Celia Grace contributed a guest editorial for the women's issue of Salient in 1987, wherein she wondered how much journalistic talent had been lost over the years at Salient due to women being shut out from its creation: “Take a look at Salient - throughout its history, it's primarily been created by men - written by men, distributed by men, edited by men. This issue is attempting to redress that imbalance a little". 147

In 1988, a regular feature titled "Sexist Bloopers" solicited students to send in instances of sexism they encountered on campus or in wider society. In return, students would know they were "participating in the cure of any ignorance about sexist language that exists in the VUW community". ${ }^{148}$ Steeds was accused of turning Salient into "an organ of "cunningly weaved feminist rhetoric"" by one correspondent while another levelled that "your magazine, or rather, our magazine is absolutely saturated with feminism to the point of nauseation". ${ }^{149}$ More women wrote for Salient in 1988. Howard was VUWSA's last Woman Vice President and she edited the women's issue of Salient that year. The issue was produced entirely by women as an "affirmation of women's capacities - that women can write, edit, and produce a paper despite a long history of largely male staff'. ${ }^{150}$ In 1989, Howard, the first woman editor of Salient since Hurley, was joined by Barbara Duke as technical editor, providing the first instance in which both of these positions

\footnotetext{
${ }^{146}$ Melissa Clark-Reynolds, 'editorial', Salient, Vol. 49, No. 23, 29 September 1986, p.2.

147 Celia Grace, 'editorial', Salient, Vol. 50, No. 9, 4 May 1987, p.2.

148 'Hands Off', Salient, Vol. 51, No. 3, 14 March 1988, p.12. Ten dollars was also awarded to the best blooper each week.

${ }^{149}$ Bernie Steeds, 'Editor', Salient, Vol. 51, No. 8, 16 April 1988, p.2; Tequila Woman, 'In Support of Tequila Man', Salient. Vol. 51, No. 10, 23 May 1988, p.20.

${ }^{150}$ Barbara, 'Editor', Salient, Vol. 51, No. 10, 23 May 1988, p.2.
} 
were filled by women. Indeed, six of the seven university newspapers in New Zealand were edited by women in $1989 .{ }^{151}$

Howard was unapologetic about using Salient as a feminist platform. As editor, Howard regularly responded to correspondents (mostly men) who claimed that the likes of the women's issue of Salient, the introduction of women-only hours at the university rec centre, and women's studies courses were sexist against men. Responding to these claims, she wrote that the "main premise of these letters has been 'Yes, things were really bad for you women ... 20 years ago, but we have changed everything now, and we think that you have equal treatment so you should shut up.' Well yes, things were really bad 20 years ago. So women got together and fought for changes ... I find it ridiculous that men think that they have the right to tell women what their lives are like". 152

On these non-education issues, Salient's political coverage was more akin to political commentary than an extension of political activism. Salient observed current events and often took stances on issues contemporary issues which were not expressed in other publications. But its editors and contributors were not involved with activism relating to those issues to the same extent as their counterparts in the 1970s. Overall, opposition to user pays was the stance which came to define Salient's political coverage and its editors' political activity in the second half of the 1980s. Salient's coverage of tertiary education policy provided a critical perspective which was not widely available elsewhere. As O'Neill noted in 1987, "student protests in France and Korea have got more media attention here than student concerns in New Zealand". ${ }^{153}$ Salient regularly interviewed high-ranking Government officials such as Marshall, Goff, and Peter Dunne, asking them difficult questions about the gulf between their alleged commitment to open, state-funded education and the material effects of their Government's policies. ${ }^{154}$ This coverage was not myopic in its opposition to user pays education; Salient's editors recognised that to oppose funding cuts to education was to oppose neoliberal policies which had caused rampant unemployment and

151 'Editorial', National Student Issue, August 1989, p.2.

152 Belinda Howard, 'Editor', Salient, Vol. 52, No. 11, 29 May 1989, p.2.

153 Grant O'Neill, 'Editor', Salient, Vol. 50, No. 15, 13 July 1987, p.2.

154 John Roberts, 'Anybody's Guess', Salient, Vol. 50, No. 7, 27 April 1987, p.4; Mike Houlihan, 'Educating Phil', Salient, Vol. 51, No. 3, 14 March 1988, pp.7-9; Anna Len, 'the douglas man', Salient, Vol. 51, No. 13, 15 June 1987, p.5. 
increased levels of inequality. ${ }^{155}$ As the editors of New Zealand's university newspapers explained in the 1989 National Student Issue, the "motives behind the student protest are the same as those behind last year's unemployment march and protest against hospital closures. We're not the only ones threatened by free-market policies". ${ }^{156}$ In these ways, Salient acted as an activist publication on the issue of education as it had for other issues in the past. Its editors used their platform to help to organise protests against user pays, and to try to directly hold its architects to account. To a significant degree, this political stance pushed coverage of other political issues to the side.

Regarding the breadth of political issues Salient covered in the 1970s, and the wider political action which had informed that reporting, Salient in the late 1980s was significantly more focused on and involved in the central issue of education. The political context was totally different - the enormity and uncertainty of user pays education demanded more attention of Salient. It lost some of its radical edge and its range of political activism as a result. Steeds, reflecting on how Salient had changed since he became involved in 1986, said that there were "less left-wing people. There's not as many on campus generally, or in New Zealand ... SALIENT covers education much more than they used to. It's more relaxed". 157

\section{Conclusion}

The 1980s were a decade of change for Salient. It went from being a newspaper which had a strong socialist influence, particularly through its association with the Workers' Communist League, a political ideology which was shared with the Victoria University Student Association. After 1981 however, this influence began to dwindle. Contributors such as Margie Thomson continued to lend a WCL presence within Salient, but increasingly its editors, while broadly leftwing and progressive, were not adherents to any particular doctrine of leftist thinking. VUWSA, meanwhile, went further to the right, abandoning much of its connection to the WCL. As a result, the relationship between Salient and VUWSA became more heated. While Salient continued to support Māori issues, like many Pākehā liberals, its contributors struggled with the more radical ideas of Māori activists such as Ripeka Evans and Donna Awatere. The ideas of Māori sovereignty

\footnotetext{
155 Philippa Mein-Smith, A Concise History of New Zealand (Cambridge: Cambridge University Press, 2012), pp.2223.

156 'Editorial', National Student Issue, August 1989, p.2.

${ }^{157}$ Bernie Steeds, 'In the last of our retrospectives, we review the last two years', Salient, Vol. 52, No. 25, 2 October 1989, p.19.
} 
were given some platform within the paper, but were also challenged and cast as separatist. Women became more prominent in Salient. It had its first women editors since 1941, and women who contributed reckoned with the male-dominated history of the publication in women-centred issues of Salient in the late 1980s. Students' optimism when a Labour Government was elected in 1984 quickly gave way to the realisation that Roger Douglas' neoliberal reforms were likely to bring user pays system to tertiary education. VUWSA and NZUSA underwent major reforms to become more responsive to this threat, prioritising opposition to tertiary education cuts and user pays over broader political issues. By the end of the decade, Salient's political content was narrowed to coverage of protest action against user pays education and analysis of new education policies. Salient did continue to report on political and social issues in ways which made it distinctive from the mainstream media. However, its editors and contributors prioritised their stance opposing user pays and neoliberal reform more generally, deploying Salient as an organising tool for action against these developments. The Salient of 1989 was different in many ways to the Salient of the 1973. Much of this was due to context - access to education was in jeopardy and the vitality of 1970s protest movements had largely dissipated. The contextual difference between Salient in these two times is well captured in the postscript of a piece of correspondence to Salient in 1989: "PS No I don't remember Paris in '68 - I was inside my mother at the time". ${ }^{158}$

158 'Casting Doubt', Salient, Vol. 52, No. 7, 17 April 1989, p.20. 


\section{Conclusion}

Salient has been published for over eighty years. In that time, it has covered a huge array of historical developments at Victoria University of Wellington (VUW), in Wellington itself, in New Zealand, and internationally. This thesis considered just two decades, the 1970s and the 1980s. Salient was swept up in the wave of protest and counter-cultural movements of the late 1960s. As individuals who were involved in these movements stepped into the role of editor, Salient was returned to the tradition A.H. 'Bonk' Scotney had envisioned in 1938 - that Salient would be a newspaper which took strong stances on the political issues its editors believed in.

Although Salient had some obligations to report on campus news and student politics, its editors possessed a significant degree of editorial freedom to take the paper in whatever direction they wished. One of its most consistent characteristics as a publication was that its editors explicitly set themselves against the reporting of the mainstream media. Salient covered stories and events which the daily press did not, and deliberately rejected the mainstream convention of "objective" reporting, believing this to be unrealistic, unattainable, and dishonest. In the view of its editors, Salient was no more or less biased than the Dominion or the Evening Post, it was simply more open about where its interests lay. The paper was produced in a grotty office in the Student Union building, which became the gathering space for a community of left-wing students on campus who volunteered their time to put Salient together each week. It was their interests and opinions, and those of the editor, which Salient represented. Salient's rejection of mainstream media convention in its content and method of production allow it to be understood as part of the wider alternative print culture of the 1970s and 1980s. Alternative print material, which included books, serials, and the more ephemeral, had a significant role in reporting on protest, organising protest, and educating activists. This was an important part of Salient's function. Salient also had to contend with the same restrictions and levels of censorship that the alternative press in Wellington did.

However, it also had some key differences to other alternative publications. Its relationship to its publisher, the Victoria University of Wellington Students' Association (VUWSA), inhibited the degree of radicalism or controversy Salient could risk engaging in, as the Association was liable for any legal costs Salient incurred. The fact that it was funded by VUWSA, through students' Association fees, also generated some accountability to the student body. Although some efforts were made to represent student interests, Salient's political positions were far from universal amongst students. Some correspondents to Salient were vocal in their frustration that 
Salient was using the paper they had paid for to push a political agenda they disagreed with. Salient's VUWSA funding also allowed it a greater degree of freedom and reliability than other alternative publications which were often erratically produced and short-lived. There is also reason to believe that Salient was widely read amongst students (despite some complaints) and that it also had something of a readership in downtown Wellington. Far more than just a campus newspaper, Salient should be viewed as a consistently produced and widely read alternative publication in Wellington.

In terms of the specifics of Salient's areas of reporting, they were many and various - more than could be covered in this thesis. In the 1970s, Salient's coverage was an extension of its editors' close integration with activist groups and movements in Wellington. Salient was "inseparable from protest". ${ }^{1}$ From 1973 until 1981, Salient had a strong a consistent line of socialist analysis which took a class-based view of society. The influence of Maoist politics through members of the Wellington Marxist-Leninist Organisation, and its successor the Workers' Communist League (WCL), though not all-encompassing was particularly important in explaining this editorial line. This manifested in Salient as strong support for militant trade unions generally, but also in ways which were relevant to Salient's student readership. As Robert Muldoon maligned and undermined trade unions, cut support to universities, and refused to adequately increase the tertiary bursary, Salient encouraged students to see their interests and those of workers as one and the same. In 1981, Salient strongly opposed the Springbok Tour. It acted as an important platform for the promulgation of information about when and how to oppose the tour, why the issue was so important, and it was intentionally a source of tour-related news which presented a record of events from the perspective of protesters. This marked the high-point of Salient as an outlet and extension of its editors' and contributors' activism.

In the early 1980s, the influence of socialist politics was on the wane. Less of its regular contributors were members of the WCL, and its editors, though broadly left-wing, did not ascribe to a particular doctrine of left-wing thinking. From 1983 VUWSA, which had likewise been influenced by the WCL, contended with a nascent right-wing element, marked by regular conflict with Salient. This signalled changing expectations students had of their Association, which were solidified in years to come. The second half of the 1980s was dominated by the threat of "user pays" education, an idea which gained traction as a part of the Labour Government's neoliberal

\footnotetext{
${ }^{1}$ Roger Steele, interviewed by Max Nichol, 16 December 2018.
} 
economic reforms. This model of funding tertiary education totally reimagined the value of tertiary education, seeing it as providing a private benefit, rather than a public good. To account for the gravity of this threat, both VUWSA and the New Zealand Union of Students' Associations, the national university student body, underwent substantial constitutional reforms. These reforms jettisoned many of the broad political activities of these organisations, which had been a significant, but contentious, element of their activities since the late 1960s. They reoriented their activities more narrowly around education issues, student interests, and student welfare. Salient followed a similar narrowing of its reporting interests, though this occurred more naturally and more gradually. Salient's editors recognised the gravity of user pays, prioritising their coverage accordingly. While it continued to report on and take positions on an array of political issues, the stance it took against user pays and education cuts was the most dominant. Furthermore, with the exception of its role in organising and reporting on protests against user pays, Salient's political content became more akin to political commentary than an extension of involvement in a range of political protest movements as had been the case in the 1970s. By the end of the 1980s, Salient had changed in many ways from the newspaper it had been in 1973.

Salient consistently featured content relating to the Women's Liberation Movement and feminism throughout the 1970s and 1980s, capturing and scrutinising the range of issues that affected women. Individual women contributed much of Salient's content relating to women's issues, but within the culture of the newspaper's staff, there were very few women in prominent positions in the 1970s. And while many of Salient's male editors were broadly supportive of Women's Liberation, women writing for Salient also had to contend with dismissive attitudes and condescension from some of its male contributors. In 1984, Sally Zwartz became the first woman editor of Salient since 1941. She was followed by Jane Hurley in 1985, Belinda Howard in 1989, and Barbara Duke in 1990. They and other women contributors not only took on a more senior roles within the paper, but also directly reckoned with Salient's historical lack of women involved in the paper's production.

Salient's engagement with Māori issues varied across the 1970s and 1980s. Roger Steele's uniquely close and personal connection to the Te Reo Maori Society on campus meant that during his editorship, there was a significant level of support for te reo Māori. Te Ao Marama, two special Māori issues of Salient, gave Māori voices particular prominence in 1973 and 1974. More generally, Salient's editors were broadly supportive of Māori struggles, often understanding these 
in class terms in the 1970s. Salient printed articles supporting significant moments in Māoridom, such as the 1975 Land March and the occupation of Takaparawhā. This support in principle for Māori struggle and an end to racism in New Zealand was carried forward in the 1980s. However, Salient's engagement with the more radical ideas of Māori sovereignty, developed by Māori activists such as Donna Awatere and Ripeka Evans following the 1981 Springbok Tour, was uneven. To some extent Salient gave these ideas a platform, exposing their readers to them. However, as was common on the Pākehā left, some contributors also expressed trepidation about what they perceived as Māori "separatism" and the challenging rhetoric of dismantling the colonial state of New Zealand. Indeed, when these ideas came to be expressed by Māori students calling for a separate Māori students association during the NZUSA restructure, Salient editor Richard Adams made it clear that he did not believe this to be a necessary or desirable outcome.

Though it has not been covered in this thesis, as a coda it is worth noting that the Salient offices have been fertile ground for New Zealand writers and journalists. Student media has long been a place for young writers and journalists to cut their teeth. All of the people interviewed for this project for example have had careers in and around the media, writing, and publishing. ${ }^{2}$ Other Salient alumni, and former editors of other student publications, likewise hold prominent public platforms within the mainstream media and New Zealand politics. The nature and significance of this transition from student "alternative" publications to more "mainstream" publications could not be explored in this thesis. But it is worth noting Salient's role not just as an alternative publication, but also role it has played in launching the careers of a large number of journalists and writers.

Student publications hold a unique place in the print landscape of New Zealand. As this thesis has demonstrated, Salient in the 1970s and 1980s did much more than simply report on the insular goings on of the Victoria University of Wellington campus. Rather, its editors and contributors looked out from their vantage point in the Student Union building, taking note of what was happening in Wellington, in New Zealand, and in the world. Through Salient, they presented

\footnotetext{
${ }^{2}$ Simon Wilson has edited a number of New Zealand magazines and more recently has been in an editorial position at media start-up The Spinoff, before moving into a role as a Senior Writer at the New Zealand Herald. Jane Hurley worked for Victoria University Press immediately after leaving Salient and worked for the Listener for a time as well. Roger Steele established Steele Roberts Aotearoa, a publishing house based in Petone. Two of their books appear in the bibliography of this thesis. Peter Franks is an historian, and has published a number of works on the history of trade unions. Margie Thomson said that Salient "gave me a career", having worked as a journalist and writer. Mark Cubey has worked in radio and publishing for many years.
} 
opinions and analysis on a diverse range of political issues. These views did not represent all students - it is questionable whether Salient could truly be said to be an "Organ of Student Opinion", purely because the student body was too large and amorphous for this to be a fully attainable ideal. Instead, Salient's editors took advantage of the newspaper's financial security and broad editorial mandate to pursue coverage of the things they thought were important in the hopes of energising and informing students. In doing so, Salient not only reflected and reported on important currents in New Zealand and international politics during the time period, but came to be closely and directly involved in them. In a history of eighty years, change has been a constant for Salient. Though writing under the same masthead, each editor had their own ideas for the direction of Salient and was writing into different historical context. What unites these disparate manifestations of Salient is a tradition which continues to this day - providing students with something to say with a platform to say it. 


\section{Appendix - Salient editors 1970-1990}

\begin{tabular}{|l|l|}
\hline 1970 & David Harcourt \\
\hline 1971 & Roger Cruickshank \& George Rosenberg \\
\hline 1972 & Gil Peterson \\
\hline 1973 & Peter Franks \& Roger Steele \\
\hline 1974 & Roger Steele \\
\hline 1975 & $\begin{array}{l}\text { Antony Ward \& Mark Derby (interim), Bruce } \\
\text { Robinson }\end{array}$ \\
\hline 1976 & John Ryall \\
\hline 1977 & David Murray \\
\hline 1978 & Simon Wilson \\
\hline 1979 & Peter Beach \\
\hline 1980 & Stephen A'Court \\
\hline 1981 & Stephen A'Court \\
\hline 1982 & Mark Wilson \\
\hline 1983 & Mark Cubey \\
\hline 1984 & Sally Zwartz \\
\hline 1985 & Jane Hurley \\
\hline 1986 & Richard Adams \\
\hline 1987 & Brant O'Neill \\
\hline 1988 & Bernie Steeds \\
\hline 1989 & Belinda Howard \\
\hline 1990 & arbara Duke \\
\hline
\end{tabular}

Source: Stephen Hamilton, A Radical Tradition: A History of the Victoria University of Wellington Students'

Association 1899-1999. Wellington: Victoria University of Wellington Students' Association and Steele Roberts Publishers, 2002, p.225. 


\section{Bibliography}

\section{Primary Sources}

Salient, published by the Victoria University of Wellington Students' Assocation, Vol. 36 - Vol. 52, 1973-1989. Available at the JC Beaglehole Room, Victoria University of Wellington.

\section{Oral Interviews}

Cubey, Mark, interviewed by Max Nichol, 5 December 2018

Franks, Peter, interviewed by Max Nichol, 20 December 2018.

Hurley, Jane, interviewed by Max Nichol, 9 February 2019.

Reid, Robert, interviewed by Cybèle Locke, 27 January 2015.

Ryall, John, interviewed by Cybèle Locke, 17 December 2014.

Steele, Roger, interviewed by Max Nichol, 16 December 2018.

Thomson, Margie, interviewed by Max Nichol, 9 December 2018.

Wilson, Simon, interviewed by Max Nichol, 8 December 2018.

\section{Secondary Sources}

\section{Published Sources}

Alcorn, Noeline. Ko Te Tangata: A History of the University of Waikato: The First Fifty Years. Wellington: Steele Roberts Aotearoa, 2014.

Atton, Chris. Alternative Media. London: Sage, 2002.

Barrowman, Rachel. Victoria University of Wellington 1899-1999: A History. Wellington: Victoria University Press, 1999.

Belgrave, Michael. From Empire's Servant to Global Citizen: A History of Massey University. Auckland: Massey University Press, 2016.

Belich, James. Paradise Reforged: A History of the New Zealanders From the 1880s to the Year 2000. Auckland: Penguin Books, 2001.

Bodman, Ryan. “"The Public Have Had a Gutsful and So Have We': The Alienation of Organized Labour in New Zealand, 1968-1975." New Zealand Journal of History Vol 48, no. 1 (2014): pp.78-108.

Boraman, Toby. "A Middle-Class Diversion from Working-Class Struggle? The New Zealand New Left from the Mid-1950s to the Mid-1970s.” Labour History Vol. 103 (November 2012): pp.203-226.

. "Revisiting the Global and Local Upheavals of 1968." Counterfutures Vol. 6 (2018): pp.36-67.

. "The Independent Left Press and the Rise and Fall of Mass Dissent in Aotearoa since the 1970s." Counterfutures Vol. 1 (2016): pp.31-70.

. "The New Left in New Zealand." In On the Left: Essays on Socialism in New Zealand, edited by Pat Maloney and Kerry Taylor, pp.117-32. Dunedin: Otago University Press, 2002. 
Bracke, Maud Anne. "The 'Spirit of 1968': Cultural Revolution.” In The Oxford Handbook of the History of Communism, edited by S.A. Smith, 156-70. Oxford: Oxford University Press, 2014.

Brewin, Mark W. "A Short History of the History of Objectivity." The Communication Review Vol. 16, no. 4 (2013): 211-29.

Brickell, Chris. Mates and Lovers: A History of Gay New Zealand. Auckland: Godwit, 2008.

—. "Sexuality, Morality and Society." In The New Oxford History of New Zealand, edited by Giselle Byrnes, pp.465-86. Melbourne: Oxford University Press Australia \& New Zealand, 2009.

Brookes, Barbara. A History of New Zealand Women. Wellington: Bridget Williams Books, 2016.

Chamberlain, Sue. Constant Radical: The Life and Times of Sue Bradford. Masterton: Fraser Books, 2017.

Clarke, Alison. Otago: 150 Years of New Zealand's First University. Dunedin: Otago University Press, 2018.

Dann, Christine. Up From Under: Women and Liberation in New Zealand 1970-1985. Wellington: Allen \& Unwin/Port Nicholson Press, 1985.

Elworthy, Sam. Ritual Song of Defiance: A Social History of Students at the University of Otago. Dunedin: Otago University Students' Association, 1990.

Gould, John. The University Grants Committee, 1961-1986: A History. Auckland: Auckland University Press, 1988.

Hamilton, Stephen. A Radical Tradition: A History of the Victoria University of Wellington Students' Association 1899-1999. Wellington: Victoria University of Wellington Students' Association and Steele Roberts Publishers, 2002.

Harris, Aroha. Hikoi: Forty Years of Maori Protest. Wellington: Huia Publishers, 2004.

Harris, Aroha, and Melissa Matutina Williams. "Rights and Revitalisation, 1970-1990." In Tangata Whenua: A History, edited by Atholl Anderson, Judith Binnney, and Aroha Harris, pp.358-86. Wellington: Bridget Williams Books, 2015.

Hercock, Fay. A Democratic Minority: A Centennial History of the Auckland University Students' Association. Auckland: Auckland University Press, 1994.

Krippendorff, Klaus. Content Analysis: An Introduction to Its Methodology, Third Edition. Thousand Oaks: SAGE Publications, 2013.

Lacy, Stephen, Kay Robinson, and Daniel Riffe. "Sample Size in Content Analysis of Weekly Newspapers." Journalism and Mass Communication Quarterly Vol. 72, no. No. 2 (Summer 1995): 336-45.

Leadbeater, Maire. Peace, Power \& Politics: How New Zealand Became Nuclear Free. Dunedin: Otago University Press, 2013.

Locke, Cybèle. "From Human Rights to Māori Sovereignty: Māori Radicalism and Trade Unions, 1967-86." In The Treaty on the Ground: Where We Are Headed, and Why It Matters, edited by Rachael Bell, Margaret Kawharu, Kerry Taylor, Michael Belgrave, and Peter Meihana, pp.73-89. Auckland: Massey University Press, 2017. . "Maori Sovereignty, Black Feminism, and the New Zealand Trade Union Movement." In Indigenous Women and Work: From Labor to Activism, pp.254-67. Chicago: University of Illinois Press, 2012. 
. "Organising the Unemployed: The Politics of Gender, Culture and Class in the 1980s and 1990s." In On the Left: Essays on Socialism in New Zealand, edited by Pat Maloney and Kerry Taylor, pp.151-68. Dunedin: Otago University Press, 2002.

. Workers in the Margins: Union Radicals in Post-War New Zealand. Wellington: Bridget Williams Books, 2012.

Locke, Elsie. Peace People: A History of Peace Activities in New Zealand. Christchurch: Hazard Press, 1992.

McAloon, Jim. Judgements of All Kinds: Economic Policy-Making in New Zealand 1945-1984. Wellington: Victoria University Press, 2013.

Mein Smith, Philippa. A Concise History of New Zealand. Cambridge: Cambridge University Press, 2012.

Phillips, Jock. “Generations 1965-1984.” In Frontier of Dreams: The Story of New Zealand, edited by Bronwyn Dalley and Gavin McLean, 337-63. Auckland: Hodder Moa Beckett, 2005.

Pollock, Jacob. “'We Don't Want Your Racist Tour': The 1981 Sprinbgbok Tour and the Anxiety of Settlement in Aotearoa/New Zealand." Graduate Journal of Asia-Pacific Studies Vol. 2, no. 1 (2004): pp.32-43.

Portelli, Alessandro. "What Makes Oral History Different." In The Oral History Reader: Third Edition, edited by Robert Perks and Alistair Thomson, pp.48-58. New York: Routledge, 2016.

Rabel, Roberto. New Zealand and the Vietnam War: Politics and Diplomacy. Auckland: Auckland University Press, 2005.

Rashbrooke, Max. "Mag Men (and Women).” FishHead, July 2012, pp.39-40.

Richards, Trevor. Dancing on Our Bones: New Zealand, South Africa, Rugby and Racism. Wellington: Bridget Williams Books, 1999.

Rosier, Pat. Twenty Years of Broadsheet Magazine. Auckland: New Women's Press, 1992.

Roth, Bert, and Janny Hammond. Toil and Trouble: The Struggle for a Better Life in New Zealand. Auckland: Methuen Publications, 1981.

Sharfe, Jean. Players, Protesters and Politicians: A History of the University of Canterbury Students' Association. Christchurch: Clerestory Press, 1995.

Sinclair, Keith. A History of the University of Auckland, 1883-1983. Auckland: Auckland University Press, 1983.

Smith, Ron. Working Class Son: My Fight Against Capitalism and War. Wellington: Ron Smith, 1994.

Walker, Geoff, and Peter Beach, eds. 56 Days: A History of the Anti-Tour Movement in Wellington. Whanganui: Citizens Opposed to the Springbok Tour, 1982.

Young, David. Our Islands, Our Selves: A History of Conservation in New Zealand. Dunedin: Otago University Press, 2004.

\section{Unpublished sources}

Bodman, Ryan. “'The Public Have Had a Gutsful and So Have We': The Alienation of Organised Labour in New Zealand, 1968-1984." Master's Thesis, University of Auckland, 2013.

Cleveland, Les. "The Structure and Function of the Press in New Zealand." MA Thesis, Victoria University of Wellington, 1970. 
Forsyth, Hannah. "The Ownership of Knowledge in Higher Education in Australia 1939-1996." $\mathrm{PhD}$ Thesis, University of Sydney, 2012.

Freemantle, Jasmine A. "Constructing Queer in Student Media: Representations of NonHeterosexuals and Non-Heterosexuality in Salient, 1938-2003." Honours Dissertation, Victoria University of Wellington, 2005.

Hart, Andrew. "Student Perspectives: Auckland University Student Newspapers in the 1960s." Honours Dissertation, University of Auckland, 2016.

Shaw, Alistair. "Telling the Truth About People's China." PhD Thesis, Victoria University of Wellington, 2010.

Simpson, Megan. "Radical Spaces: New Zealand's Resistance Bookshops, 1969-1977.” MA Thesis, Victoria University of Wellington, 2007. 